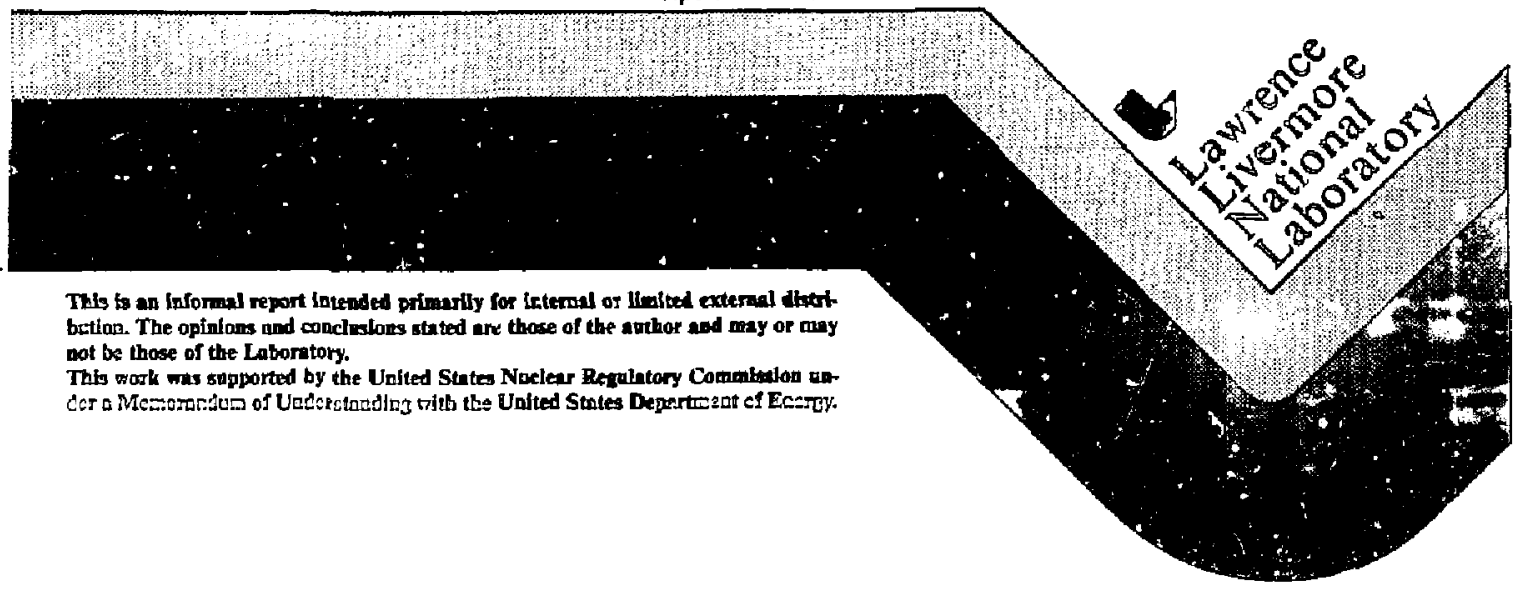




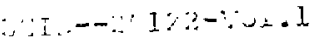 \\ $\therefore \therefore<17303$
}

\section{SSI RESPINSE OF $A$ \\ TYPICAL SHEAR WALL \\ STRUCTURE}

\section{DISCLAIMER}

\begin{abstract}
This report was prcpared as an account of work sponsoted by an agency of the Unired States Government. Nerther the United States Gowernment nor any agence thereof. bor any af their employees. makes any warr: nly. express or implied, uf assumes any legal liability cur responst-

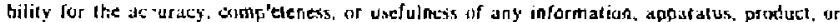
process disclosed, or sepresents that its use would nul infringe privately uwned rights Reforence hurein to any specufic commercial product. process, ar serwhe hy its de name, trademark. manufacturer, or otherwise does nol necessarily consbfule or imply its endorsernent. recom-

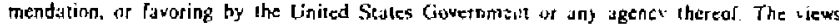
ind upinions of authors expressed hetein do nol necessarily sliste or reflect thase of the Uniled Staltes (juvernmenl or any agericy thereor.
\end{abstract}

BY

J. J, JOHNSON

E. C, SEHEWE

0. R. MASLENIKOV

PREPARED FOR

LAWRENCE LIVERMORE NATIONAL LABORATORY

APRIL 1984
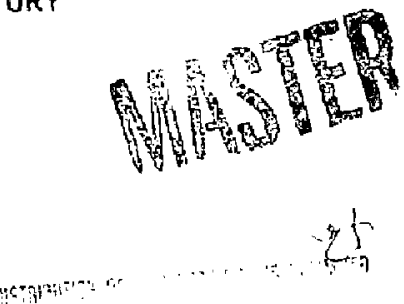


\section{ABSTRACI}

The Simplified Methods Project of the US NRC - funded Seismic Safety Margins Research Frogram (SSMRP) has as its goal the development of a methodology to perform routine seismic probabilistic risk assessments of comercial nuclear power plants. The study reported here develops calibration factors to relate best estimate response to design values accounting for approximations and simplifications in SSI analysis procedures. Nineteen cases were analyzed and in-structure response compared. The structure of interest was a typical shear wall structure. 
TABLE OF CONTENTS

Page

ABSTKACT . . . . . . . . . . . . . . . . . . . i

LIST OF FIGURES. - . . . . . . . . . . . . . . . . . vi

LIST OF TABLES . . . . . . . . . . . . . . . . . . . $x$

EXECUTIVE SUMMARY. . . . . . . . . . . . . . . . . . xiii

1.0 INTRODUCTION. . . . . . . . . . . . . . . . . 1-1

1.1 BACKGROUND . . . . . . . . . . . . . . . . 1-1

1.2 OBJECTIVES AND SCOPE . . . . . . . . . . . . . 1- 1-

2.0 TYPICAL SHEAR WALL STRUCTURE. . . . . . . . . . . 2-1

2.1 PhYSICAL STRUCTURE ............... 2- 1

2.2 STRUCTURE MOdE .............. . . $2-4$

2.3 RESPONSE QUANTITIES. . . . . . . . . . . . . 2-7

3.0 ELEMENTS OF THE SSI ANALYSIS. . . . . . . . . . . . $\sum_{-1}$

3.1 GENERAL. . . . . . . . . . . . . . . . . . 3-1

3.2 FREE-FIELD GROUND MOTION ............ . 3-3

3.3 SOLl PRDFILES. . . . . . . . . . . . . . . . 3-7

3.4 FOUNDATION IMPEDANCES. . . . . . . . . . . 3-8

3.4.1 Surface Foundation Impedances...... . 3-8

3.4.2 Embedded Foundation Impedances. . . . . 3-20

3.4.3 Frequency Independent Impedances. . . . . 3..27

3.5 THE STRUCTURE MODEL. . . . . . . . . . . 3-29 
TABLE OF CONTENTS (Continued)

Page

4.0 NUMERICAL RESUltS . . . . . . . . . . . . . . . 4-1

4.1 GENERAL. . . . . . . . . . . . . . . . . 4- 1

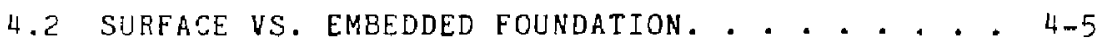

4.3 FIXED-BASE VS. (SURFACE AND EMBEDDED FOIJNATIONS) . . . . . . . . . . . . . . 4-16

4.4 SOIL SPRINGS VS. ( FOUNDATIONS) . . . . . . . . . . . . . . 4-34

4.5 EFFECT OF INCREASED STRUCTURE DAMPING. . . . . . 4-45

5.0 CONCLUSIONS ...................... 5-

6.0 REFERENCES ....................... 6- 1

$\begin{aligned} \text { APPENDIX A - } & \text { CAIEGOHIZATION OF NUCLEAR POWER } \\ & \text { PLANT CHARACTERISTICS. . . . . . . . A-2 } \\ \text { APPENDIX B - } & \text { IN-STRUCTURE RESPONSE SPECTRA } \\ & \text { COMPARISONS. . . . . . . . . . . . . Vol. 2 }\end{aligned}$ 
2.1 Simplified Plan View of the Zion, Illinois, Nuclear Power Plant. The Shaded Area-Comprising the Fuel-Handling, Auxiliary, and Diesel Generator Buildings--is the Subject of this Study. . . . . . . . . . . . . 2-3

2.2 Seation of the Auxiliary/Fuel-Handling/

Diesel-Generator Complex through the Plane of Symmetry. . . . . . . . . . . . . 2-3

2.3 Perspective View of the Model Lookjng Southwest. . . . . . +. . . . . . . . 2-5

2.4 Perspective Vien of the Model Looking West... . . . . . . . . . . . . 2-5

2.5 Plan View of Model Shows (X, Y) Coordinates. . . 2-6

2.6 Half Section of Model Illustrating Node

Points at which Peak Acselerations and

In-Structure Response Spectra are Generated. . . 2-11

2.7 Plan View of Model Showing Walls for which

Forces and Moments were Calculated . . . . . 2-12

3. 1 Mean and Mean-Plus (and Minus)-One Standard Deviation Response Spectra for

Ten Earthquakes Generated to Match RG 1.60

Design Spectra (5\% Damping); (a) North-South

(Y) Directior, (b) East-West (X) Direction,

(c) Vertical (z) Direction . . . . . . . . . 3-4

3.2 Plan View of the Surface-Foundation Model

Including the Discretization for

Calculating Impedances. . . . . . . . . . 3-10

3.3 Impedances for the Uniform Half-Space;

$v_{s}=500 \mathrm{fps}$; Surface Foundation . . . . . . 3-11 
LIST OF FIGURES (Cortinued)

Page

3.4 Impedances for the $71 \mathrm{ft}$. Soil Layer over

Bedrock; $V_{s}=1000$ fps; Surface Foundation. . 3-14

3.5 Impedances for the $110 \mathrm{ft}$. Soil Layer over

Bedrock; $V_{s}=1000 \mathrm{fps}$; Surface Foundation, . 3-17

3.6 Impedances for the Uniform Half-space;

$v_{s}=500 \mathrm{fps}$; Embedded Foundation . . . . . . 3-21

3.7 Impedances for the $110 \mathrm{ft}$. Soll Layer over

Eedrock; $V_{s}=1000$ fps; Embedded Foundation. . 3-24

4.1 Comparison of In-Structure Response Spectra

at Node 256; Surface vs. Embedded Foundation

(a) Uniform HaIf-space, $v_{s}=3500$ fps,

Case 2/Case 6............... . . 4-8

4. $\mathfrak{i}(\mathrm{b})$ Uniform Half-space, $V_{s}=2000 \mathrm{fps}$,

Case 3/Case 7. . . . . . . . . . . . 4-9

4.1(c) Uniform Half-space, $V_{s}=1000 \mathrm{fps}$,

Case 4/Case 8;............... 4-. 40

$4.1(d)$ Uniform Half-space, $v_{s}=500 \mathrm{fps}$,

Case 4/Case 8;.............. 4-11

4.1 (e) $110 \mathrm{ft}$. Layer over Bedrock, $V_{s}=2000 \mathrm{fps}$

Case 10/Case 12;............... 4 4-12

$4.1\left(f^{\prime}\right) 110 \mathrm{ft}$. Layer over Bedrock, $v_{s}=1000 \mathrm{fps}$,

Case 11/Case 13; . . . . . . . . . . . . . 4-i3.

4.1 (g) $71 \mathrm{ft}$. Layer Surface vs. $110 \mathrm{ft}$. Layer

Embedded, $v_{s}=2000$ fps, Case 14/Case 12;. . . 4-14

4.1(b) $71 \mathrm{ft}$. Layer Surface vs. $110 \mathrm{ft}$. Layer

Embedded, $V_{5}=1000$ fps, case 15/Case 13;... 4-15

4.2 Comparizon of In-Structure Response

Spectra at Node 256; (a) Fixed-base vs

Uniform Half-space, Surface Foundation, $v_{s}=3500 \mathrm{fps}$, Case 1/Case 2;......... 4-20 
LIST OF FIGURES (Continued)

Page

4.2(b) Fixed-base vs. Uniform Half-space,

Surface Foundation, $v_{s}=2000 \mathrm{fps}$,

Case 1/Case 3;................. . 4-21

4.2(0) Fixed-base vs. Uniform Half-space,

Surface Foundation, $v_{s}=1000 \mathrm{fps}$,

Case 1/Case 4;. . . . . . . . . . . . 4-22

4.2(a) Fixed-base vs. Uniform Half-space,

Surface Foundation, $v_{s}=500 \mathrm{fps}$,

Case 1/Case 5;.................. 4-23

4.2(e) Fixud-base vs. Uniform Half-space,

E.mbedded Foundation, $v_{s}=3500 \mathrm{fps}$,

Case 1/Case 6;. . . . . . . . . . . . . 4-24

4.2(f) Fixed-base vs. Uniform Half-space,

Embedded Foundation, $v_{s}=2000$ fps,

Case 1/Case 7;. . . . . . . . . . . . . 4-25

4.2(g) Fixed-base vs. Uniform Half-space,

Embedied Foundation, $v_{s}=1000 \mathrm{fps}$,

Case 1/Case 8 ;. . . . . . . . . . . . 4-26

4.2(h) Fixed-base vs. Uniform Half-space,

Embedied Foundation, $v_{s}=500 \mathrm{fps}$,

Case 1/Case 9;. . . . . . . . . . . . . . . 4-27

4.2(i) Fixed-base vs. $110 \mathrm{ft}$. Layer over Bedrock,

Surface Foundation, $v_{s}=2000 \mathrm{fps}$,

Case 1/Case 10;............... 4-28

$4.2(j)$ Fixed-base vs. $110 \mathrm{ft}$. Layer over Bedrock,

Surface Foundation, $v_{s}=1000 \mathrm{fps}$,

Case 1/Case 11;... . . . . . . . . . 4-29

4.2(k) Fixed-base vs. $110 \mathrm{ft}$. Layer over Bedrock,

Embedded Foundation, $v_{s}=2000 \mathrm{fps}$,

Case 1/Case 12;............ 4- . 4-30 


\section{LIST OF FIGURES (Continued)}

Page

4.2(1) Fixed-base vs. $110 \mathrm{ft}$. Layer over Bedrock,

Embedded Foundation, $v_{s}=1000$ Eps,

Case 1/Case 13;... . . . . . . . . . . . 4-31

4.2(m) Fixed-base vs. $71 \mathrm{ft}$. Layer over Bedrock

Surface Foundation, $V_{s}=2000 \mathrm{fps}$,

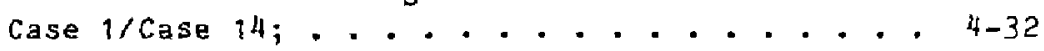

$4.2(n)$ Fixed-base vs. 71 ft. Layer over Bedrock,

Surface Foundation, $v_{s}=1000 \mathrm{fps}$,

Case 1/Case 15;................ 4-33

4.3 Comparison of In-structure Response

Spectra at Node 256; Soil Springs vs.

Uniform half-space; (a) $v_{s}=3500 \mathrm{fps}$,

Surface Foundation, Case 16/Case 2; . . . . . 4-37

$4.3(\mathrm{~b}) \quad V_{s}=2000 \mathrm{fps}$, surface Foundation,

Case 17/Case 3;.............. . . 4-38

$4.3(\mathrm{c}) v_{s}=1000 \mathrm{fps}$, surface Foundation,

Case 18/Case 4;. . . . . . . . . . . . . 4-39

$4.3(d) \quad v_{s}=500$ fps, surface Foundation,

Case 19/Case 5;................. 4 4 40

$4.3(e) v_{s}=3500$ fos, Embedded Foundation,

Case 16/Case 6;................. 4-4 4

$4.3(f) \quad V_{s}=2000 \mathrm{fps}$, Embedded Foundation,

Case 17/Case 7;................ 4-42

$4.3(\mathrm{~g}) V_{s}=1000 \mathrm{fps}$, Embedded Foundation,

Case 18/Case 8;... . . . . . . . . . . . . 4-43

$4.3(\mathrm{~h}) \mathrm{v}_{\mathrm{s}}=500 \mathrm{fps}$, Embedded Foundation,

Case 19/Case 9;................ 4-44 
2.1 Node Point Locations for Calculation of Feak Accelerations and Generation of In-Structure Response Spectra. . . . . . . . . 2-9

2.2 Locations of Shear Wall sections for Response Calculation. . . . . . . . . . . . . 2-10

3.1 Linear Frequency Independent Impedances for Uniform Half spaces . . . . . . . . . . 3-28

3.2 Percent of Total Mass Participating in each Mode.... . . . . . . . . . . . 3-30

3.3 Description of Signifleant Fixed-Base Structure Modes . . . . . . . . . . . . 3-32

4.1 Identification of Pnysical and Analysis Scenarios . . . . . . . . . . . . . . . . 4-4

4.2 Mean Ratios of Forces and Peak Accelerations for Surface vs. Embedded Foundation Conditions (Half-Space and Layered Sites) . . . . .4-6

4.3 Mean Ratios of Spectral Accelerations for Surface vs. Embedded Foundation Conditions over the Specificd Frequency Range (Halfspace and Layered Sites). . . . . . . . . . .4-7

4.4 Mean Ratios of Forces and Peak Accelerations for Fixed-Base vs. (Surface and Embedder Foundations; Half-space and Layered Sites). . . . 4-18 4.5 Mean Ratios of Spectral Accelerations for F1xed-Base vs. (Surface and Embedded Foundations; Half-space and Layered Sites) over the Specified Frequency Range. . . . . . .4-19 


\section{LIST OF TABIES (Continued)}

Page

4.6 Mean Ratios of Peak Accelerations for sril

Springs ys. (Surface and Embedded; Half-

space Site).................. . . . . . . 35

4.7 Mean Ratios of Spectral Accelerations

for Soil Springs vs. (Surface and Embedded

Foundations; Half-space Site) over the

Specified Frequency Range. . . . . . . . . . 4-36

4.8 Mean Ratios of Forces and Peak Accelerations

for Surface Foundation Conditions at 4\%, 7\%,

and $10 \%$ Structure Damping (Half-space Site). . . \$-46

4.9 Mean Ratios of Spectral Accelerations for

Surface Foundation Conditions at $4 \%, 7 \%$,

and $10 \mathrm{~g}$ Structure Damping over the Specified

Frequency Range (Haif-space Site... . . . . 4-47

A1 Plant Classification . . . . . . . . . A-5

A2 Plant Identification.............. A-18

A3 Distribution of Plants by Site

Classification and Soil Model. . . . . . . . A-21

A4 Distribution of Flants uy Method of

Generting In-Structure Forces, by

Number and Method of Combination of

simultaneous Earthquake components and

by Method of Combining Modal Response. . . . . . A A-22

A5 Distribution of PJants by Damping Ratio

usad for Welded Steel vamponents and by

Design Ground Response Spectrum. . . . . . . . A-23

A6 Cistribution of Plants by Damping Ratio

used for Bolted steel components and by

Design Ground Kesponse Spectrim. . . . . . . . A-24 


\section{LIST OF TABLES (Continued)}

Page

A7 Distribution of Plants by Damping Tatio used for Reinforced Concrete Components and by Deslgn Ground Response Spectrum . . . . A-25 Distribution of Plants by Damping Ratio used for Prestressed Concrete Components and by Design Ground Response Spectrum . . . . . A-26 


\section{EXECUTIVE SUMMARY}

The Seismic Safety Margins Research Program (SSMRP) is ar U.S. Nuclear Regulatory Commission-funded multiyear research program conducted by Lawrence Livermore National Laboratory (LLNL). Its objective was to develop a complete, fully coupled analysis procedure (includirg methous and computer programs) for estimating the $r i s k$ of earthquake-induced radioactive release from a commercial nuclear power plant. The full SSMRP analysis procedure is based on a state-of-the-art seismic and systems analysis process and explicitly includes the uncertainties inherent in such a process. It is readily apparent that tr.e tools, codes, and data bases developed to-date by the SSMRP comprise a most complete and comprehensive seismic probabilistic risk assessment (PFA) methodology. However, application of the SSMAP methodology in its entirety on a routine basis for all commercial nuclear power plants is too time consuming and costly. The goal of the SSMRP Simplified Methods Project is to develop a simpliiried methodology for routine seismic PRA's of commercial nuclear power plants.

Estimating three aspects of seismic response of structures and components is essential to a seismic PRA: median-level response, variability of response, and correlation of response for each level of the seismic hazard. In the SSMRP to-date, these aspects were determined calculationally using the computer program SMACS. To reduce the effort in a seismic PRA, it is proposed to use $A-E$ and vendor developed seismic responses and/or models to the extent possibie, Developing median level responses based on design information requires calibration, i.e. removing conservatism or non-conservatism from the design procedure. At least iwo procedures exist to do so: use generically developed calibration factors which quantify design 
prooedures and parameters vs. best estimate; or perform limited re-analysis of the nuclear power plant for which the seismic PRA is being performed using best estimate procedures and utilizing the results in the systems analysis and for calibration purposes. The seismic response of structures was the subject of this study.

The objectives of this study were two-fold:

- Develop building response calibration facturs, i.e. factors which relate best estimate or median level response to responses oalculated by selected design procedures. Soil-structure interaction was the phenomenon of interest because significant simplifications are frequently introduced in its treatment. This objective may be viewed as adoressing the question: How much conservatism is introduced by ignoring SSI or by approximating SSI effects $b ;$ a simplified procedure?

- The second objective can similarly be viewed in the context of a question: What effect does placing an identical stmucture on different sites and with different foundation conditions have on structure response?

The structure selected for this study is a part of the zion AFT complex. Only the auxiliary, fuel-bandling, and diesel generator buildings were studied. This structure is a connected group of shear-wall buildings construcied of reinforced conorete, typical of nuclear power plant structures. The bases of comparison for this study were structure responses: peak in-structure accelerations (27 components), and peak wali forces and moments (111 components). In-structure response spectra were considered to a limited extent. 
The basic approach was to analyze the structure for a series of site and foundation conditions. Best estimate and design procedures were used. Comparisons between best estimate results allows one to quantify the effects of placing t.le identioal structure on different sites and founding it in different manners. Comparisons between responses calculated by simplified SSI design procedures and those calculated by best estimate procedures, allows one to develop calibration factors. These factors can be used to estimate median level responses from design values accounting for SSI analysis procedures.

Two soil profiles were consldered: a uniform half-space of varying stiffness characteristics $\left(V_{s}=500 \mathrm{fps}\right.$, $1000 \mathrm{fps}, 2000 \mathrm{fps}$, and $3500 \mathrm{ffs}$; and a single soil layer overlying a stiff bedrock -- two thicknesses $(71 \mathrm{ft}$. and 110 $\left.f t_{.}\right)$and two layer stiffnesses ( $V_{s}=1000 f_{p s}$ and 2000 fps) were treated. Also, a fixed-base condition served as an additional case. One set of analyses treated the structure as being surface-founded; a second set assumed it to be embedded an average depth of $39 \mathrm{ft}$. which corresponds to an equivalent e/r ratio of 0.35 .

Nineteen basic cases were analyzed. Cases 1-15 represent best estimate scenarios provided the analysis scenario matches the physical characteristics of the soil, structure, and foundation. Cases 16-19 represent scenarios with simplifications in the SSI analysis procedure - namely, constant, frequency independent soil springs representing the behavior of the soil and no treatment of radiation damping. In these 19 cases, structure damping was a uniform $4 \%$ of eritical for all struciure modes. An additional senstivity study on structure damping was performed for three site conditions (fixed-base, uniform half-spaces of $1000 \mathrm{fps}$ and $2000 \mathrm{fps}$ ). The 
effect of structure damping on in-structure response bas assessed.

Each of the nineteen cases was analyzed for a series of ten earthquakes targeted to the NRC R.G. 1.60 design ground response spectra. Comparisons between cases were made earthquake-by-earthquake and point-by-point and combined ratios of response developed. Hence, mean response ratios and their variability are presented here.

From the nineteen cases, several basic comparisons were made:

- Surface vs. embedded foundation. Mean ratios of peak accelerations and forces ranged from 1.17 to 1.75 with the surface-founded case higher.

- Fixed-base us. (surface and embedied foundations). Muan ratios of peak accelerations and forces ranged from .86 to 2.73 with the fixed-base case higher except for the 71 ft. soil layer over a stiff bedrock. In this latter case, a resonant condition occurs which increases its reponse.

- Soil springs vs. (surface and embedded foundations). Mean ratios of peak accelerations ranged from 1.53 to 3.12 .

These ratios serve as calitration factors when appropriate.

Finally, a comparison of peak accelerations and forces for different values of structure damping was made. Structure damping is shown to be an important parameter only for the 
rixed-base foundation condition. Whenever SSI is properly modeled and the site can be characterized as soil rather than extremely stiff rock, changes in structure damping have a minimal effect on response. 


\subsection{INTRODUCTION}

\section{$1.1 \quad$ BACKGROUND}

The Seismic Safety Margins Research Program (SSMRf) is a US NRC funded, multiyear research program cunducted by Lawrence Livermore Natjonal Laboratory (LLNL) [?]. Its objective has to develop a complete, fully coupled analysis procedure (including methods and computer programs) for estimating the risk of earthquake - induced radioactive release from a commercial nuclear power plant, and to determine major contrihutors to the frequency of racioactive releuse. It is readily apparent that the tools, codes, and data bases developed to date by the SSMRP comprise a most complete and comprehensive seismic probabilistic risk assessment (PRA) methodology. Its application to the zion nuclear power plant is documenteo in Ref. 2. Hovever, application of the SSPRP methodology in its entirety on a routine basis for all commercial nuclear power plants is too time consuming and costly. The goal of the simplifizd methods project is to develop a simplified methodology for routine seismic PRA's of commercial nuclear power plants. This methodolony will be hased on the SSMRP Phases I and II methodology and results.

Seismic risk analysis can be considered in five steps: seismic hazard characterization (seismic hazard curve, frequency characteristics of the motion); seismic resporse of structures anc components; structure and component failure descriptions; plant logic models (fault trees and event trees); and probabilistic failure and release calculations. This study concentrates on the seismic response of structures as it pertains to a seismic PRA. 
To perform a seismic risk analysis, seismic responses are required for all structures and zomponents contained in the plant logic models (typically, fault trees and event trees). $0 \hat{~}$ course, some culling, preferably on a probabilistic basis, will be performed to reduce the rotal number of structures and components of importance to estimation of risk. Typical examples of items for which responser may be required are floor or 1 ire mounted vajues, pipes, pumps, diesel generator, electrical components such as circuit breakers, electrical busses, etc., structures, structural elements, and so forth. A sejsmic tisk analysis considers not simply ore or two levels of earthquake (such as $O B E$ and $S S E$ ) but the range of possible earthquakes at the site. Three aspects of seismic response, for each earthquake level, are necessary for seismic rist analysis: best estimate or median level response, variabijity of response, and correlation of responses.

Median level response. "The best estimate or median levei seismic response given an earthquake occurrence is required. In general, best estimare response differs from the design values, even for the desigr level earthquake, because, in the latter case, design cinalysis procedures, parameter sejection, and qualification procedures are conservativesy biased. An adoitional consideration due to anajyzing for the range of earthquakes of the seismic hazard curve is the change in properties of the soij/structure/piping systems which occurs as higher excirations lead to lower soil shear moduli, Inwer structure frequencies, and higher sojl and structure damping characteristics. Such changes need to be taken intc account when determining best estimate response.

Variability of response. Variability in seismic response resulting from variations in the earthquake excitation, the 
physcial properties of the soil/structure/piping system and our ability to model then must be estimated.

Crrrelation of responses. Correlation of responses, i.e., the tendency for pairs of responses to have simultaneously high or low values, results from two sources--the level of the earthquake and the dyramic characteristics of the system. The level of the earthquake affects correlation since a large earthquake (large peak acceleration) may cause all responses to be large, whereas a small earthquake produces the opposite effect. The second source of correlation is due to system response itselr. Far example, floors within a structure may all experience high values of response simultaneously due to the dynamic characteristics of the structure itself. Hence, equipment supported on these floars may simultanecusly have high response. The importance of response correlation on probabilities of systemi failure, core melt, and radioactive release depends on correlations between fragilities and the functional characteristics of the systems themselves.

For SSMRP seismic risk analysis methodology to da:e, these three aspects of seismic response were determined calculationally using the computer program SMACs - - Seismic Methodology Analysis Chain with Statistics [3]. Considerab]e resources are required to perform the SMACS analysis from start to finish. The major effort is associated with developing models of soil-structure interaction (SSI), major structures, and piping systems and coordinating the models for input to SMACS. Jne proposed approach to reduce the effort in this aspect of the seismic PRA for the SSMRP Simplifier lethodology is to use A-E and vendor developed seismic responses and/or models to the extent possible. In addition, use SSMRP Phases I and $I I$ information to define variability and cortelation of the seismic responses. 
1.2 OBJECTIVES AND SCOPE

Developing median level responses based on existing design information is cesirable for performing a seismic PPA. At least two approaches exist to use A-E and vendor generated seismic responses in the seismic PRA. Both approaches are based on calibrating the data - estimating median jevel responses (wall forces and moments, in-structure response spectra. in-structure accelerations, etc.), as a function of earthquate: level removing conservatism or non-conservatism from the A-E procedure. The th'o approaches are:

- Develop a set of calibuation factors for response quarticies of interest based on comparing best estimate results with results of a design procedure.

- Perform limited re-analysis of the nuclear power plant for which the seismic PRA is being performed. Generate seismic responses to be used in the systems analysis and to calibrate the A-E generated data. The re-analysis hould concentrate on the structures with minimal or no effort devoted to re-analyzing piping systems. In-structure response spectra could be generated to caljbrate conservatism in input to $\mathrm{F}_{\mathrm{r}} \mathrm{ing}$ systems. The cost of such a re-analysis could be significantly reduced by using A-E generated structural models if they were adequate and availabie.

The objectives of this study were two-fold:

- The first objective was to develop bujlding response calibration factors, i.e. factors which relate best estimate or median level response to responses calculated by selected design procedures. The 
phenomenon of interest for this objective and the following was SSI fiects because significant simplifications are frequently introduced in its treatment. Also, the behavior of the structure is intimately coupled with the soil when founded on a soil site and the soil and structure must be treated as a system. This objective may be viewed as addressing the question: How much conservatism is introduced by ignoring SSI or by approximating SSI effects by a simplified procedure?

- The second objective can similarly be viewed in the context of a question: What effect does placing an identical structure on different sites and with different foundation conditions have on structure response?

This effort concentrates on structure response - - wa11 forces and moments and in-structure accelerations - - with only a limited effort on subsystem response as represerted by in-siructure response spectra. The structure of interest was a shear wall structure intended to be representative of a typical nuclear power plant building. A parallel study with the subject structure being a containment shell and internals was performed and reported separately. Section 2 describes the structure.

Section 3 describes the key elements of the SSI analyses performed: the free-field ground motion, the soil profiles, the foundation embedment conditions, the foundation impedances, the structure model, and simplified SSI parameters used in a selected number of cases.

Section 4 presents numerical results in the form of response comparisons. 


\subsection{TYPICAL SHEAR WALL STRUCTURE}

2.1

PHYSICAL STRUCTURE

The structure of interest is a part of the zion auxiliary-fuel handling-turbine building (AFT) complex of the zion nuclear power plant. Only the auxiliary, fuel-handing, and diesel generator buildings were modelied for this investigation. These structures are a connected group of heavy, shear-wal] buildings constructed of rejnforced concrete, typical of nuclear power plant structures. In plan view, the buildings form a T-shaped unit with a plare of symmetry along the east-kest axis, leading to uncoupled horizontal response alorg the plane of symmetry and coupled horjzontal and torsional iesponse in the perpendicular plane. Figure 2.1 shows a plan view of the 2 ion ruclear power plant; the portion of the AFT complex studied here is shown shaded. Figure 2.2 shows a cross-section through the structure [2].

The auxiliary building rests on a five ft. thick, soil-supported, reinforced concrete mat at elevation $542 \mathrm{ft}$. The reinforced concrete foundation walls are laterally supported by concrete floor slabs at elevations 560,579 , and $592 \mathrm{ft}$. The diesel generator rooms at the north and south ends of the auxiliary building rest on walls extending to a strip footing at elevation 557. Above grade, the lateral force resisting system is a combination of braced structural steel frames and concrete slabs and walls. The floors at elevations 617,630 , and $642 \mathrm{ft}$. are reinforced concrete slabs supported by horizontal braced steel framing. Between the auxiliary and turbine buildings is a common shear wall. It consists of vertical, braced steel frames encased in reinforced concrete. The total mass and stiffness of this wall was included in the model. The fuel-handing building also rests on a reinforced concrete mat foundation. Reinforced 
concrete walls rise on the three exterior sides to the roof. There are partial floor slabe at elevations 602 and $617 \mathrm{ft}$. The roof is corrugated metal decking with a concrete slab supported by steel framing. 


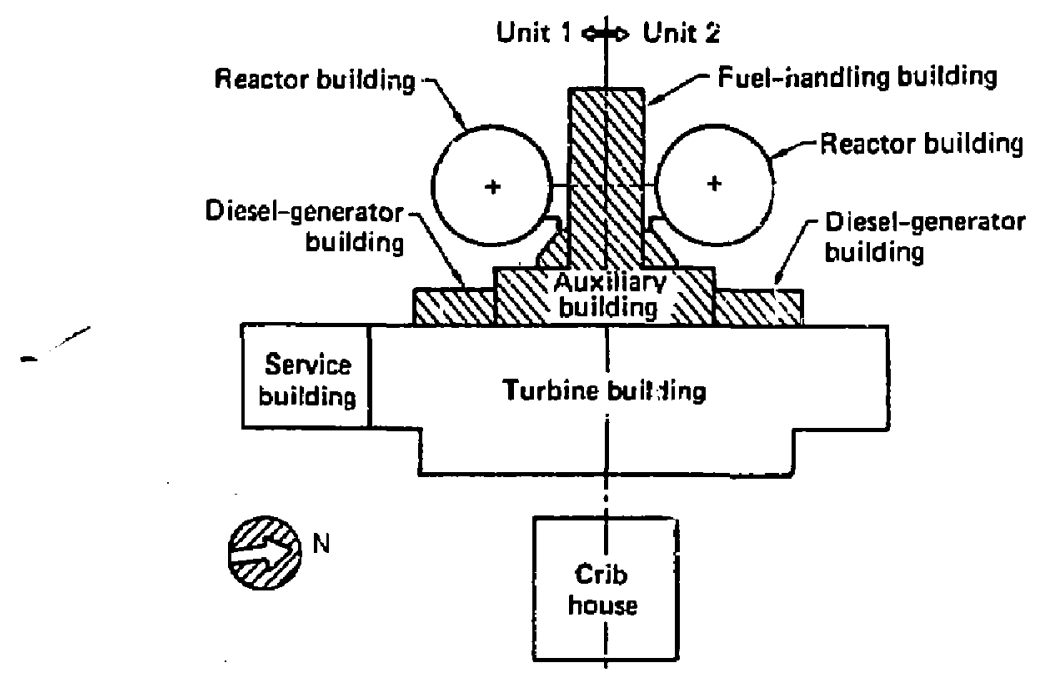

Fig. 2.1 Simplified Plan View of the zion, Illinois, Nuclear Power Plant. The Shaded Area-Comprising the Fuel-Handling, Auxiliary, and Diesel Generator Buildings-- is the subject of this study.
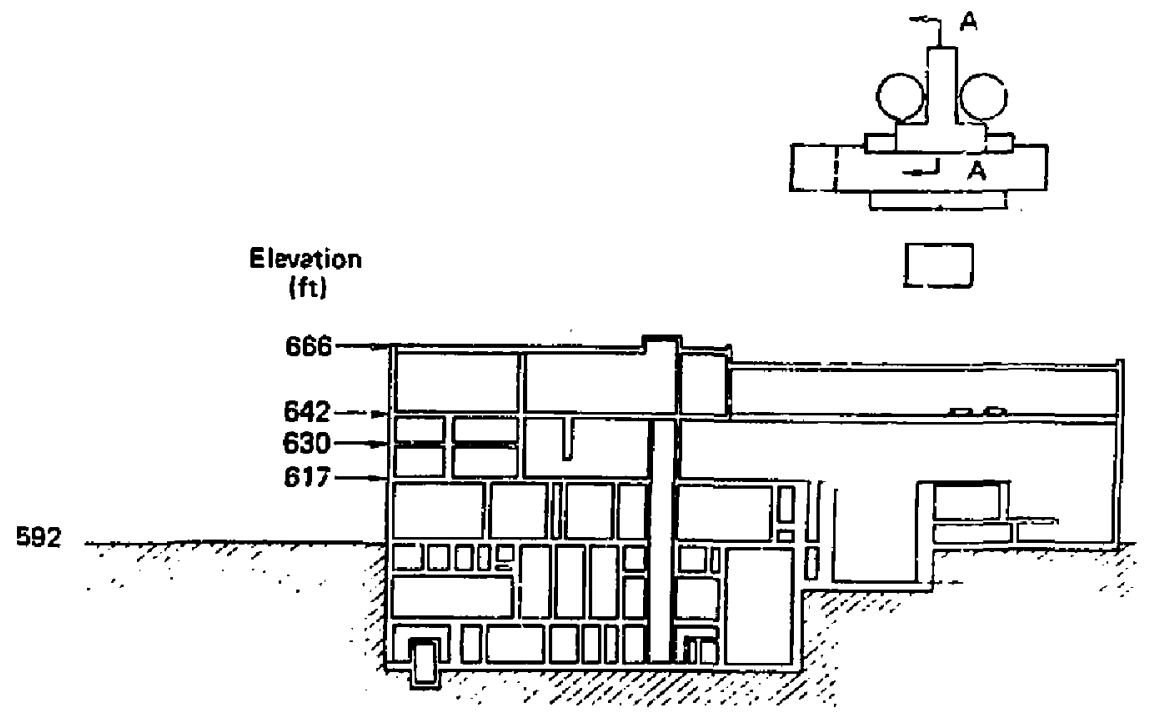

Fig. 2.2 Section of the Auxiliary/Fuel-Handling/Diese:Generator Complex through the Plane of Symnerry. $2-3$ 
2.2 STRUCTURE MODEL

The structure complex was represented by a finite Element modei. Th1s represents a best-estimate idealization of the structure, as the fewest simplifying assumptions were applied during its development. Thin plate and shell elements were chosen to define the stiffness of both concrete shear walls and floor slabs. The additional stiffness due to the steel bracing frames in the common auxiliary turbine building wall was iEpored. In discretizing the structure model, single elements were used to model the height of the shear wals between adjacent slabs. Whenever possible, element dimensions were chosen to give an aspect ratio close to unity. This discretization approach led to the use of 841 nodes and 1251 plate/shell elements. For the fixed-base model; there were a total of 3948 dynamic degrees-of-freedom. Several views of the model are shown in Figs. $2.3,2.4$, and 2.5 . The mass of selected equipment was included in the floor slab densities. 


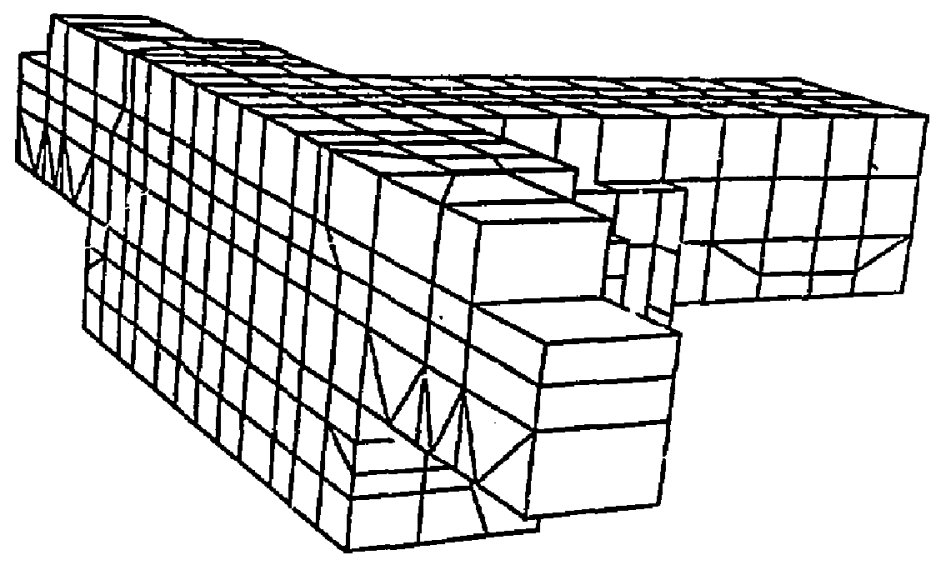

Fig. 2.3 Perspective View of the Model Looking Southwest.

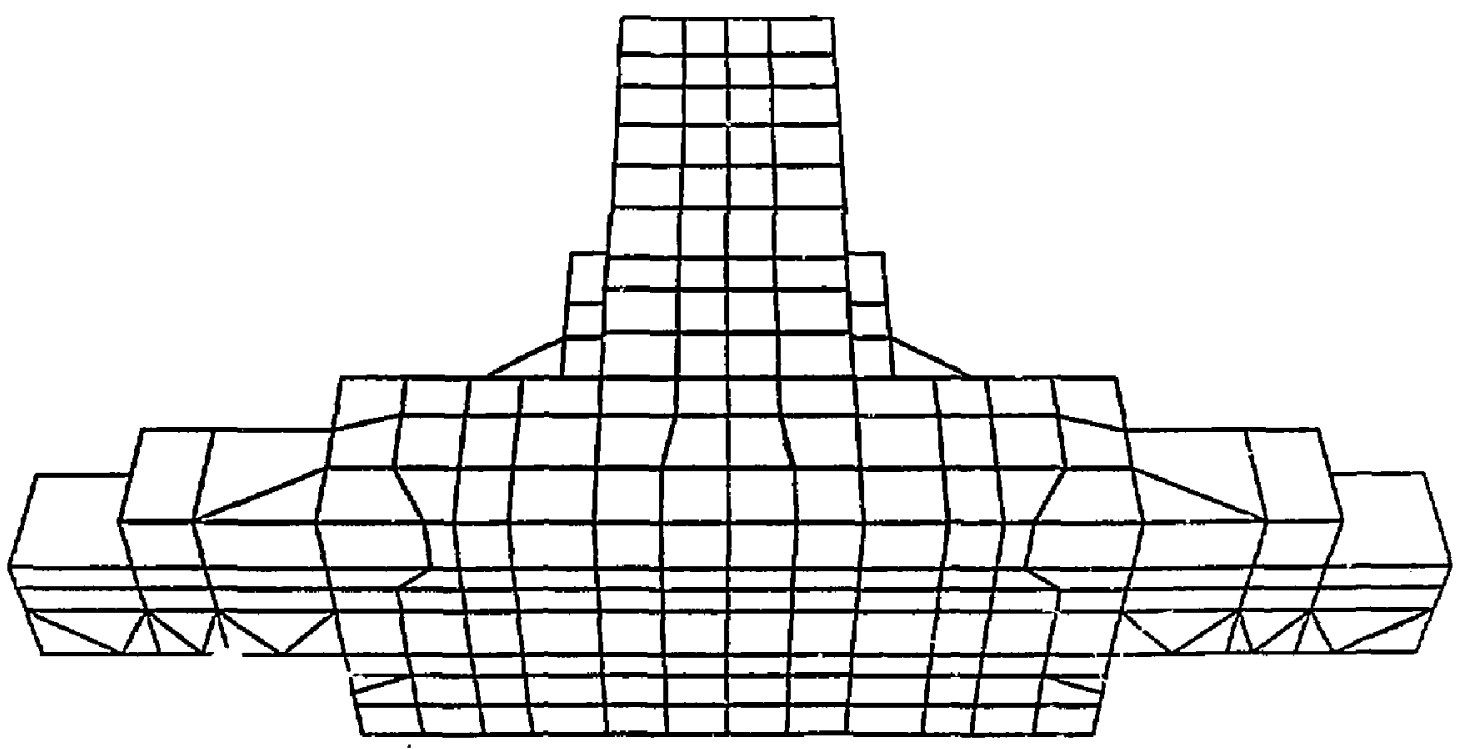

Fig. 2.4 Ferspective View of the Model Looking West.

$$
2-5
$$




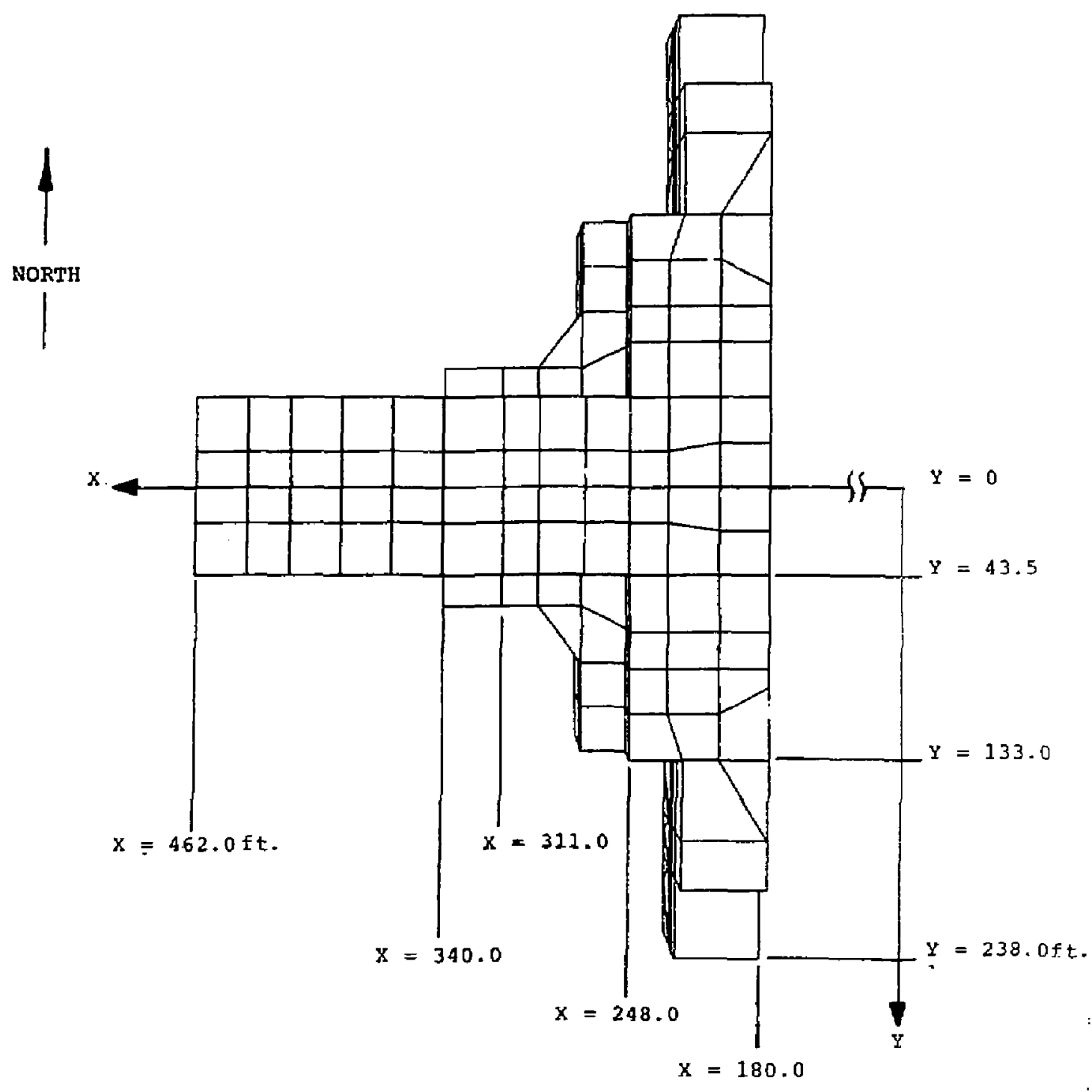

Fig. ?.5 Plan View of Model shows $(X, Y)$ Courdinates. 2-6 
In-structure accelerations, in-structure response speotra, and wall forces and moments were the dynamic response quantities of interest for this study. Node point and element locations were selected to represent overall structural behavior and local response. Peak accelerations and in-structure response spectra were calculateo at selected nodes described in Table 2.1 and shown in FIB. 2.6. In Fig. 2.6, half of the structure has been removed to better lllustrate node point locations. Wall forces and overturning moments were calculated at the roof and floor slab elevations in the major load carrying walls. Responses in the minor walls were omitted from this study. To study shear wall behavior, sections were taken in the selected walls and axial load, In-plane shear force, and overturning moment were calculated. The wall forces and moments are a summation of the elemental forces over the wall length at the section elevation. The wall sections included in this study are tabulated in Table 2.2. The wall locations in the model are illustrated in FiB. 2.7. The :alls studied include the common auxiliary-turbine bullding wall $(X=180.0)$, a major north-south auxiliary building wall $(X=248.0)$, an end wall in the fuel-handling bldg. $(X=462.0)$, a major auxiliary buliding east-west wall $(Y=43.5)$, the common diesel generator auxiliary building wall ( $Y=133.0)$, a diesel generator building wall ( $Y$ = $238.0)$, and two sections in major north-south walls in the auxiliary bullding $(X=311.0$, and $X=340.0)$. Our data base for this study consisted of:

Three components of peak acceleration (two horizontal and the vertical) at seven node points and six cumponents of peak acceleration (three translational and three rotationaly on the foundation - a total of twenty-seven. 
- Response spectra ( 2 damping) at seven nodes (three components) and on the foundation (six components) - a total of twenty-seven.

- Axial load, in-plane shear, and overturning moment in eight walls - a total of thirty-five sections, and six foundation responses (three forces and three moments) a total of 111 responses. 
Table 2.1 Node Point Locations for Calculation of Peak Accelerations and Generation of In-Structure Response Spectra.

Node

Number

10

78

147

188

256

303

672

\begin{tabular}{ccc}
\multicolumn{3}{c}{ Coordinates } \\
$229.5 \mathrm{ft}$. & $0 . \mathrm{ft}$. & $592.0 \mathrm{ft}$ \\
462.0 & 0. & 617.0 \\
222.0 & 197.0 & 617.0 \\
462.0 & 0. & 642.0 \\
229.5 & 0. & 666.0 \\
222.0 & 197.0 & 666.0 \\
229.5 & 0. & 579.0
\end{tabular}


Table 2.2 Locations of Shear Wall Sections for Response Calculation.

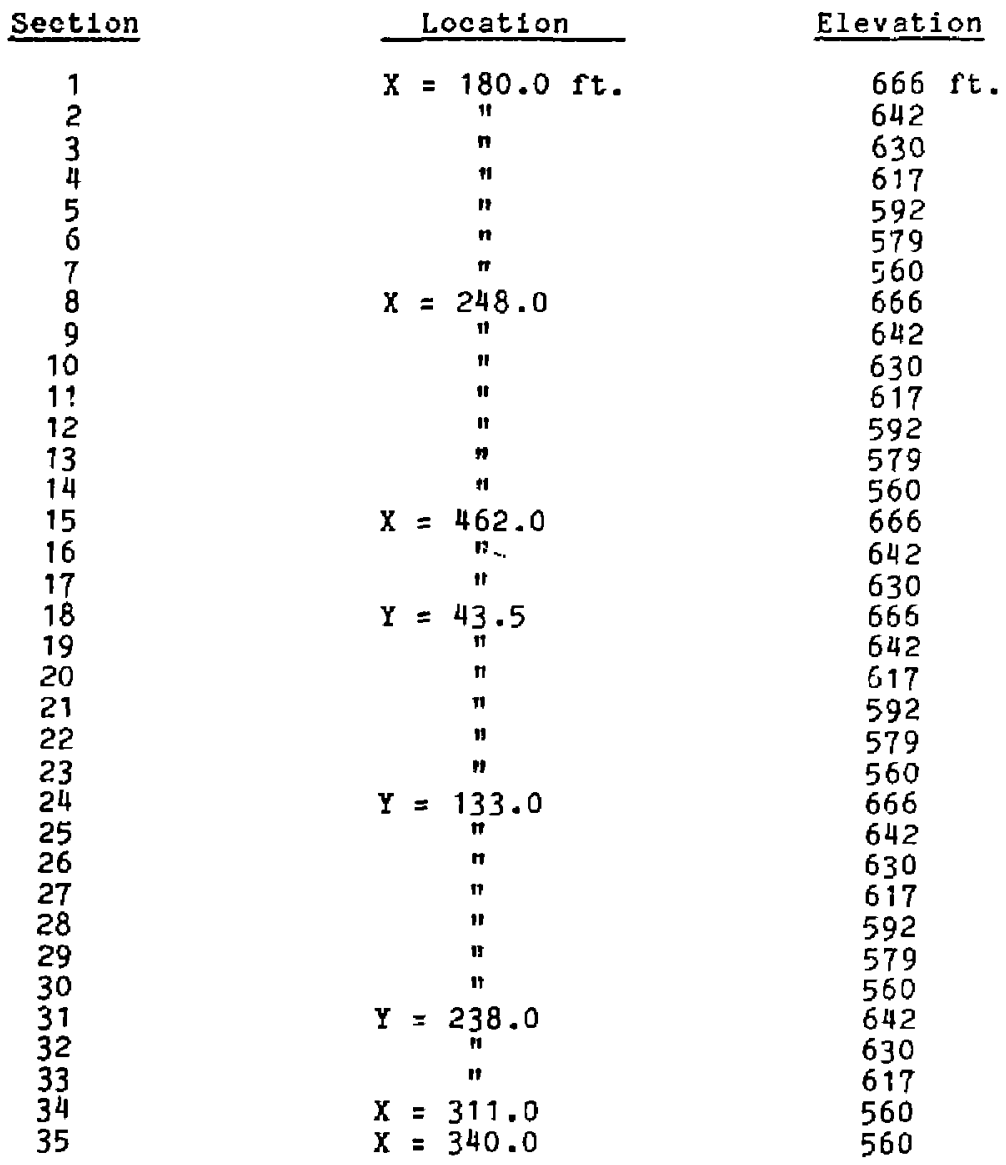




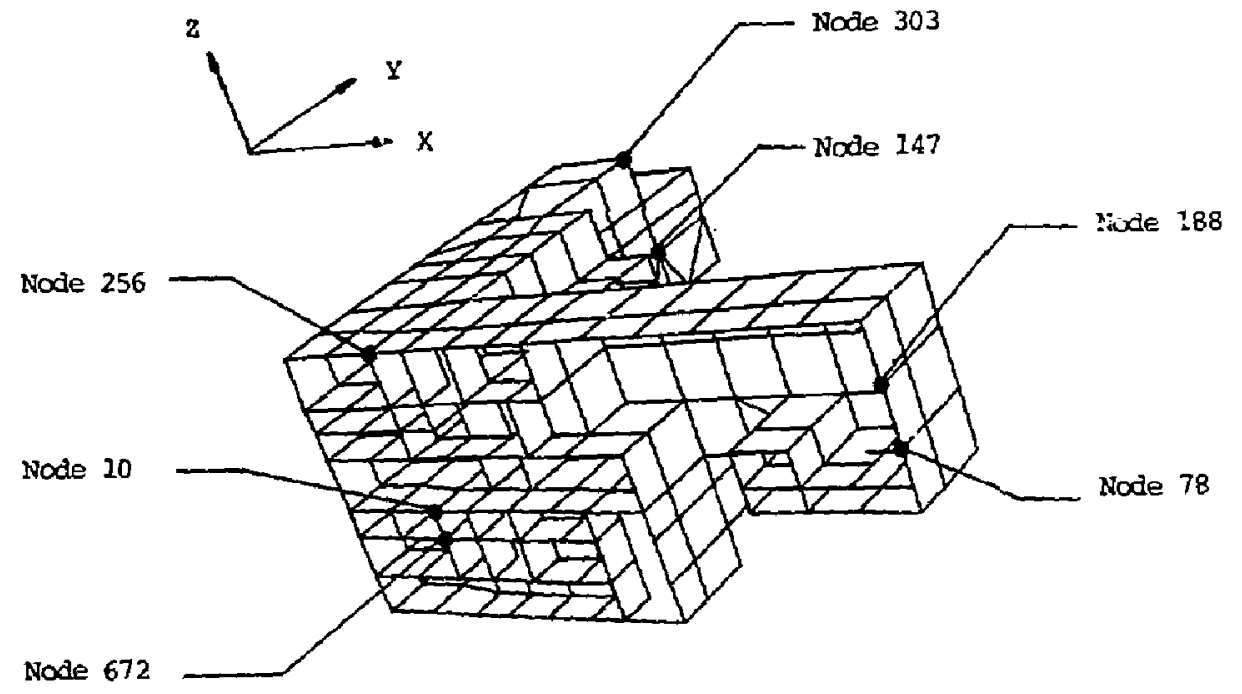

Fig. 2.6 Half Section of Model Illustrating Node Points at which Peak Accelerations and In-Structure Response Spectra are Generated. 


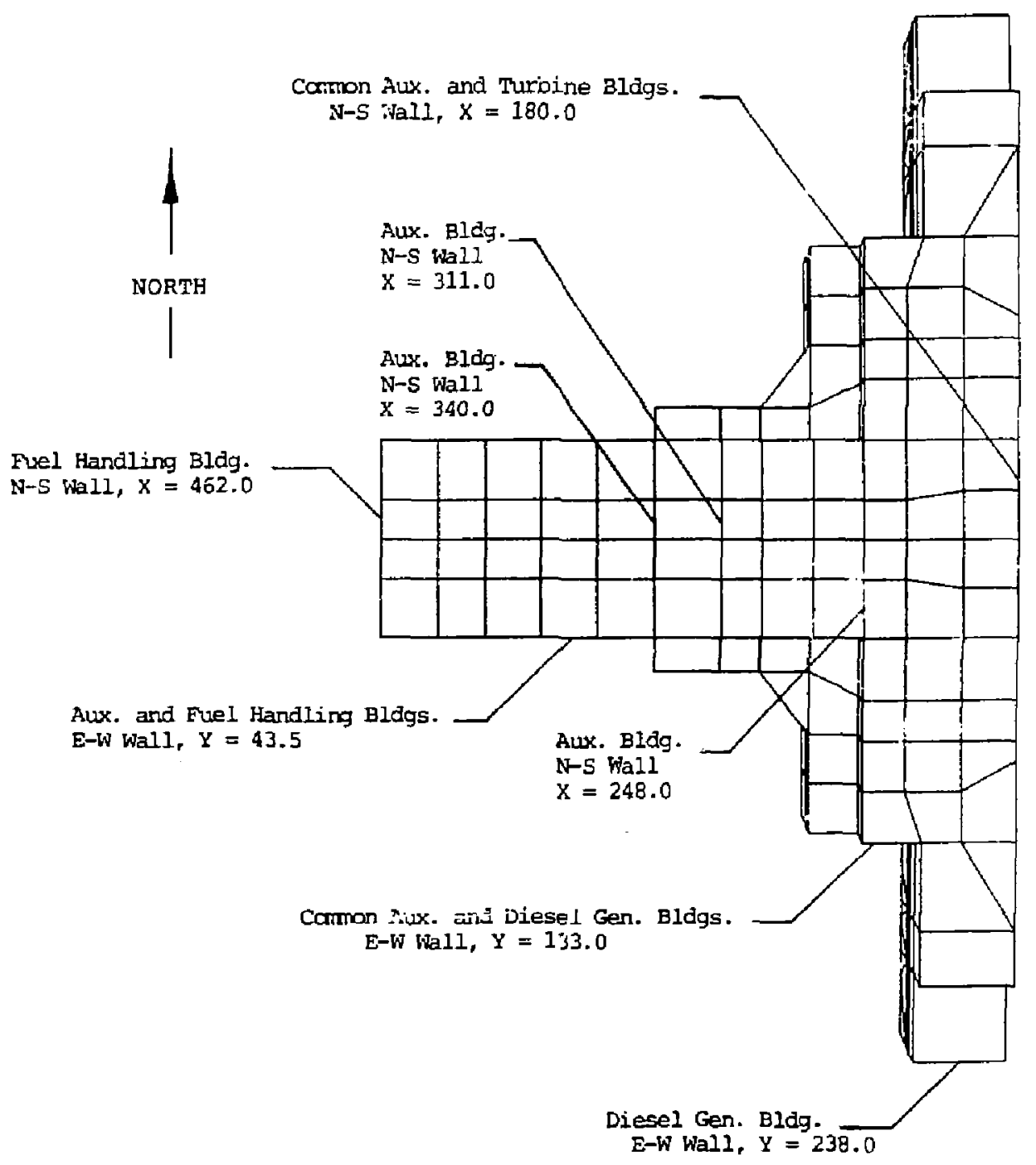

Fig. 2.7 Plan View of Model showing iralls for which Forces and Moments were Calculated. 
The basic elements of any SSI analysis (cast in the format of the substructure approachl are specifyjig the free-field ground motion, calculating the foundation input motion, calculating the foundation impedances, determining the dynamic characteristics of the structure, and performing the SSI anajyis, i.e. combining the previous steps to calculate the response of the coupled soil-structure system. Each aspect is described in general belok, followed by detajus of the present study. Our best estimate analysis included consideration of all aspects of SSI.

Free-field ground motion. Specification of the free-field ground motion entails specifying the control point, the frequency characteristics of the control motion (typica)ly, time histories or response spectra), and the spatial variation of the motion.

Foundation input motion. In general, the foundation input motion differs from the free-field ground motion in all cases, except for surface foundations subjected to vertically incident waves. First, the free-field motion varies with soil depth. Second, the soli-foundation interface scatters waves because points on the foundation are constrained to move according to its geometry and stiffness. The foundation input motion is related to the free-field ground motion by means of a transformation defined by a scattering matrix [S(w)], which is complex valued and frequency depentent:

$$
\left\{U^{*}(w)\right\}=[S(w)]\{f(w)\}
$$


The vector $\{f(\omega)\}$ is the complex Fourier transform of the free-field ground motion, which contains its complete description. For surface-founded structures subjected to vertically incident waves or for SSI analysis where embedment effects are ignored, the foundation input motion is assumed to be ilentical to the free-field ground motion. This latter instance is $;$ source of conservatism which was quantified here.

Foundation impedances. Foundation impedances $\left[K_{s}(\omega)\right]$ describe the force-displacement characteristics of the soil. They depend on the soil configuration and material behavior, the frequency of the excitation, and the geometry of the foundation. In general, for a linear elastic or viscoelastic material and a uniform or horizontally stratified soil deposit, each element of the impedance matrix is complex-valued and frequency dependent. For a rigid foundation, the impedance matrix is a $6 \times 6$ matrix whinh relates a resultant set of forces and moments to the six rigid-body degrees-of-freedom. Simplifications are many times invoked; in particular, ignoring frequency dependence of the impedances and the specific non-regular geometry of the foundation.

Structure model. The dynamle characteristics of the structure to be analyzed are frequently described by 1 ts fixed-base modes. In the present study, our best estimate analyses and simplifications thereof use this form.

SSI analysis. The final step in the substructure approach is the actual SSI analysis. The results of the previous steps -foundation input motion, foundation impedances, and structure model -- are combined to solve the equations of motion for the coupled soil-structure system. 
As ensemble of ten sets of three components of acceleration time histories (two horizonta) aligned in the north-south and east-west directions and the vertical) defined the frequency characteristics of the free-field ground motion. Each set was generated to match the design response spectra of the US NRC Regulatory Guide 1.60. The three components were distinct and verified to be statistically independent. Preliminary studies showed comparable results, i.e. comparisons as presented in Sec. 4, using this RG 1.60 data set or a set of more realistically defined acceleration time histories. Ten earthquakes were used to average out the effects of a single excitation and provide stable results. Figure 3.1 shovis mean and mean-plus (and minus)-one-standard-deviation response spectra for the data set.

In all of the analyses, the control point was defined on the surface of the soil and the wave propagation mechanism was assumed to be vertically propagatiag shear and dilatational haves - hence, defining the spatial variation of motion when included in the SSI analysis. Specification of the control point and the spatial variation of motion in conjunction with assumptions made in the SSI analyses themselves define the relationship between the free-field ground motion and the foundation input motion. For surface-founded structures and structures with embedded foundations for which embedment effects are ignored in the SSI analysis, the foundation input motion is identical to the free-field ground motion. For structures with embedded foundations and embedment is included in the SSI analyses, foundation input motion is calculated from the free-field ground motion by applying the scattering matrices. 


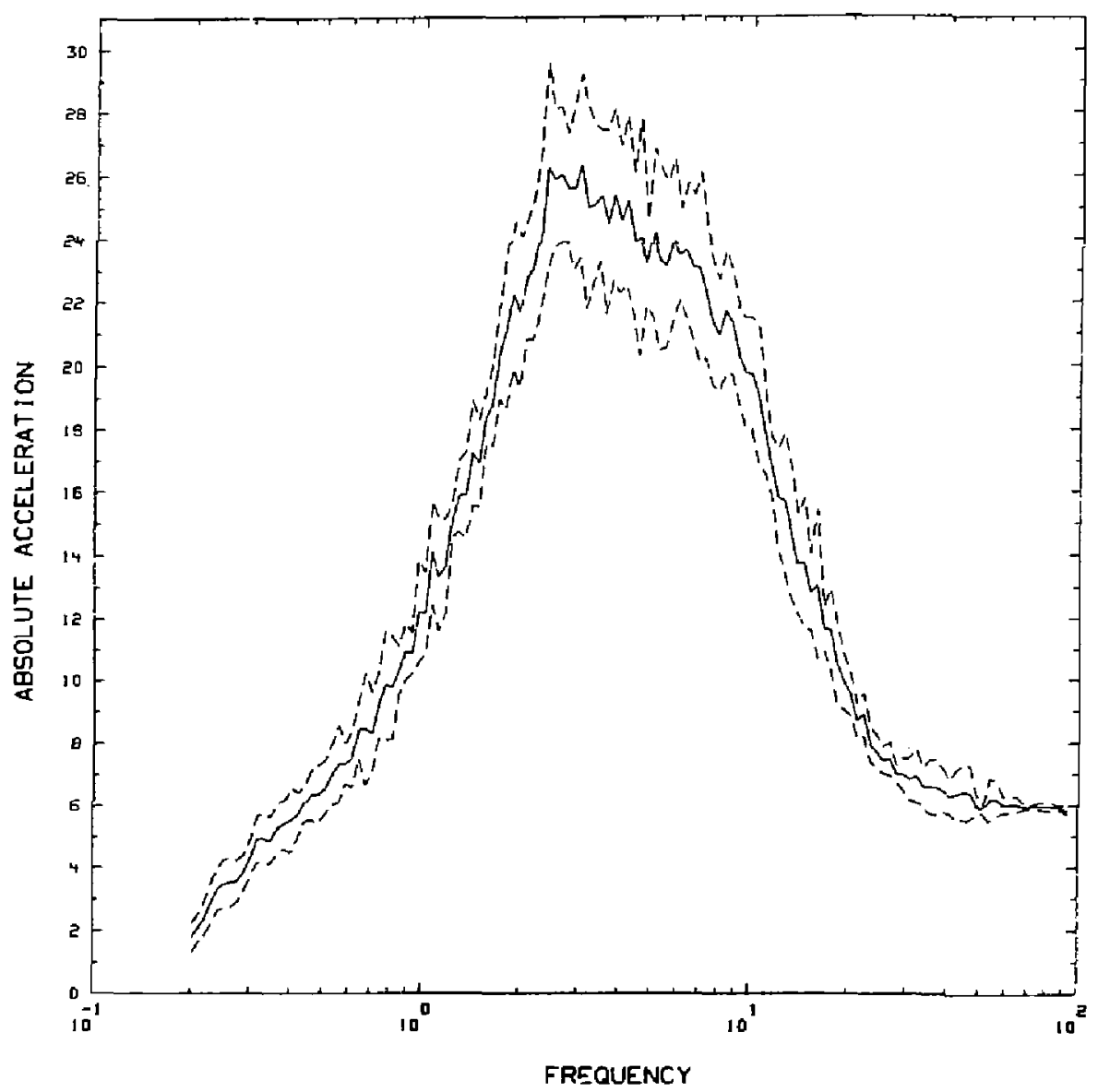

Fig. 3.1 Mean and Mean-Plus (and Minus)-One Standard Deviation Response Spectra for Ten Earthquakes Generated to Match RG 1.60 Design Spectra (58 Damping): (a) North-South ( $Y$ ) Direction, (b)

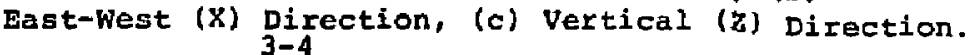




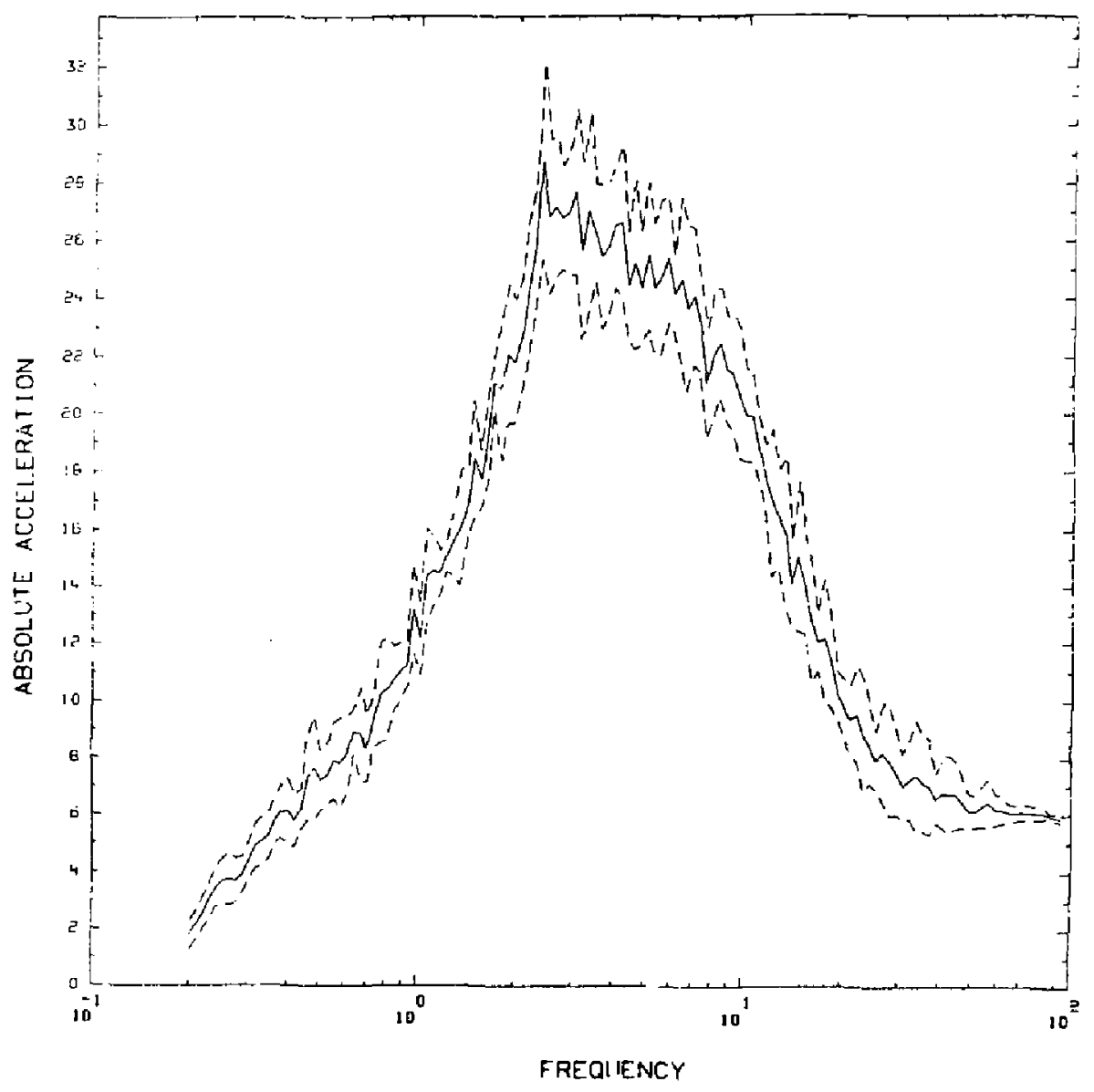

Fig. 3.1b (Continued). 


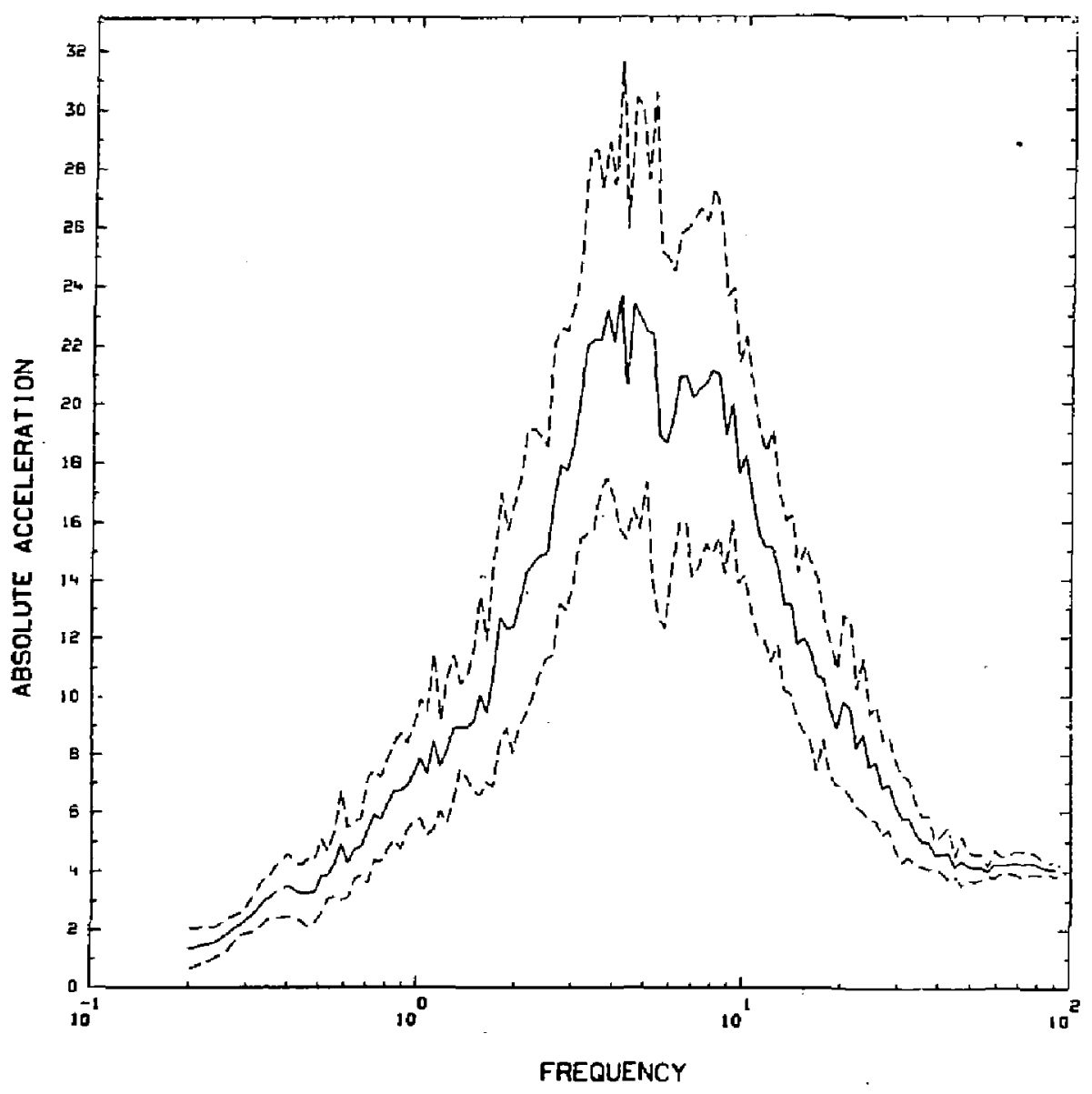

Fig. 3.1c (Continued).

$$
3-6
$$




\subsection{SOIL PROFILES}

Two basic soil profiles were considered. The first was a uniform half-space with varying stiffness characteristics defined by shear wave velocities $\left(V_{s}\right)$ of 500 fps, 1000 fps, 2000 fps, and $3500 \mathrm{fps}$. In all cases, the soil density was assumed to be 130 pef, Poisson's ratio was 0.4 , and material damping in the soil was 5 of critical.

The second basic soil profile was a single layer of soil overlying a stiff bedrock. Two layer thicknesses of $71 \mathrm{ft}$. and $110 \mathrm{ft}$. were considered. Two soil layer stiffnesses characterized by shear wave veiocities of $1000 \mathrm{fp}:$ and $2000 \mathrm{fps}$ were considered. other properties of the soil layer remained constant, i.e. density of 130 pef, Poisson's ratio of 0.4 and material damping of 5 of critical. The characteristics of the bedrock sere a shear wave velocity of $9000 \mathrm{fps}$, density of 130 pcf, Poisson's ratio of 0.27 , and material damping of 5 of critical.

One additional case was analyzed - a fixed-base condition. 
The present investigation centers on a series of analyses for various site conditions, embedment conditions, and assumptions in the SSI analysis. Modeling the soil is the key element in the studies. For our best estimate analyses, i.e. those cases which model the frequency-dependence of impedances and include scattering matrices for embedded foundations, the following general procedure was followed. For each distinct soil profile (uniform half-space, $71 \mathrm{ft}$. layer over bedrock, and $110 \mathrm{ft}$. layer over bedrock), impedances and scattering matrices were calculated explicitly for one set of material properties. The softest soil properties of interest were used in the expicit calculation to ensure adequate treatment of the frequency range of interest for stiffer soils. Using these impedances and scattering matrices as base cases, the scheme incorporated in SMACS and described in detail in Ref. 3 was used to derive the sSI parameters for differing soil material properties. For the uniform half-space case, impedances and scattering matrices were calculated for the shear wave velocity of $500 \mathrm{fps}$ and the $1000 \mathrm{fps}, 2000 \mathrm{fps}$, and $3500 \mathrm{fps}$ cases were derived from it. For the $71 \mathrm{ft}$. and the $110 \mathrm{ft}$. layer cases, impedances and scattering matrices were calculated for a layer with a shear wave velocity of 1000 fps and the 2000 fps cases were derived from them.

The following sections describe the development of the impedances and present their values.

\subsubsection{Surface Foundation Impedances}

The founcation is idealized as a flat, T-shaped surface foundation. Figure 3.2 shows a plan view of the modej's geometry, including the discretization used in computing the 
impedances. This idealization retains the basic characteristics of the foundation's dynamic behavior, such as different horizontal and rocking impedances for the two horizontal directions and appropriate coupling terms. The resulting impedances are a best estimate of the foundation's behavior. The reference point location, i.e. the point about which the impedances were calculated, is shown in Fig. 3.2, and was selected to minimize the coupling impedances between horizontal and torsional motion and vertical and rocking motion. It is approximately at the center of gravity for the foundation which is somewhat coincidental.

The surface foundation impedances for the three base cases are shown in Fig. 3.3 - 3.5: uniform half-space, $v_{s}=500$ fps, in Fig. 3.3; $71 \mathrm{ft}$, layer, $v_{s}=1000 \mathrm{fps}$, in Fig. 3.4; and $110 \mathrm{ft}$. layer, $V_{S}=1000 \mathrm{fps}$, in Fig. 3.5. 


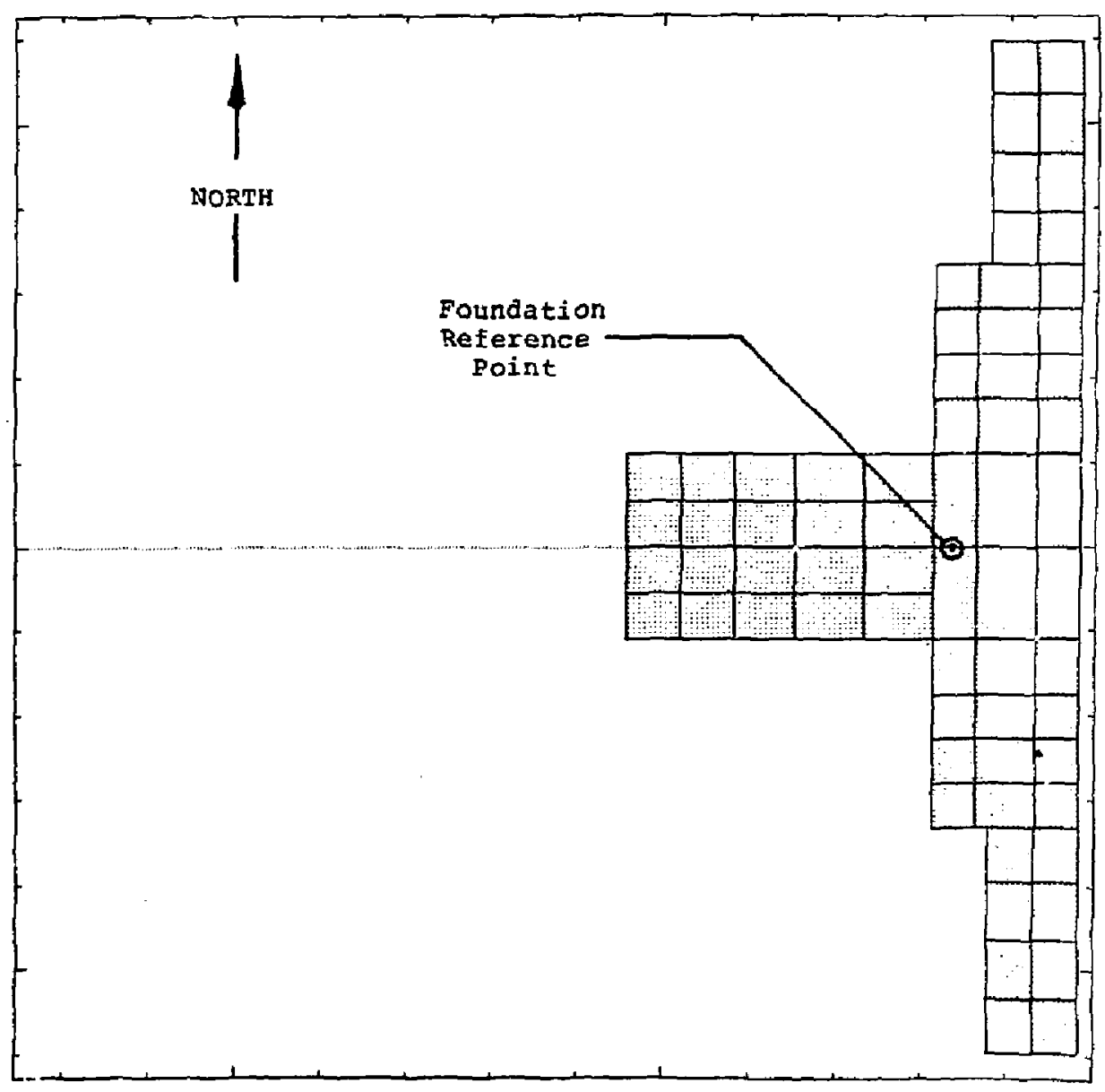

Fig. 3.2 Plan View of the Surface-Foundation Model Including the Discretization for Calculating Impedances. $3-10$ 

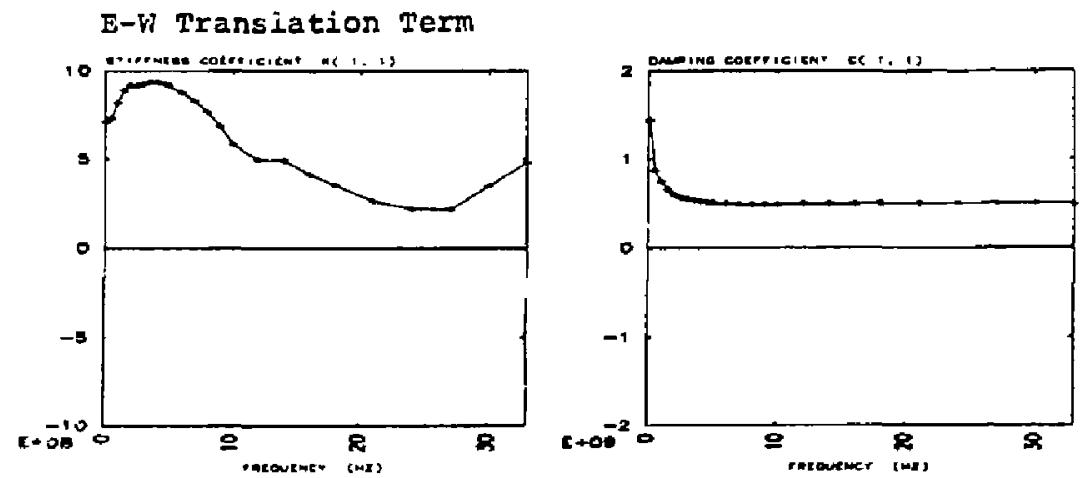

E-W Translation/Rocking Coupling Term
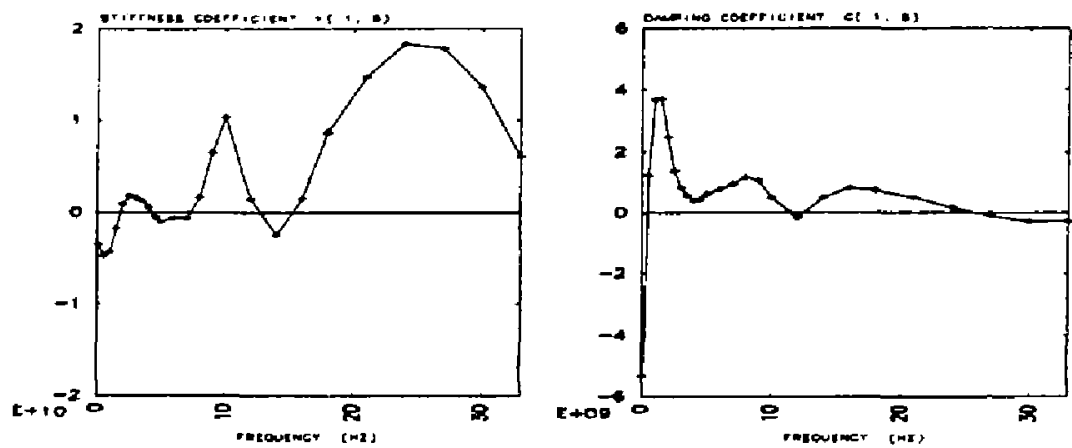

E-W Rocking Term
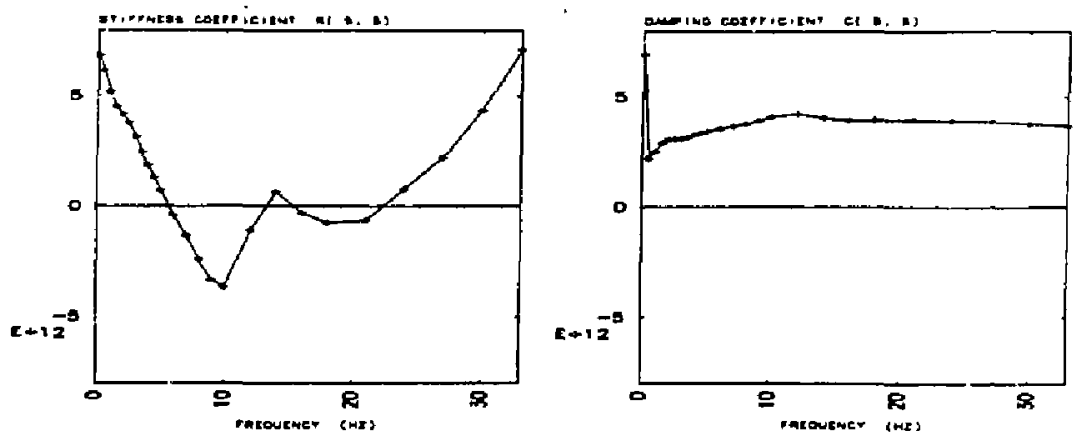

Fig. 3.3 Impedances for the iniform Half-Space; $v_{s}=500 \mathrm{fps}$; Surface Foundation. 

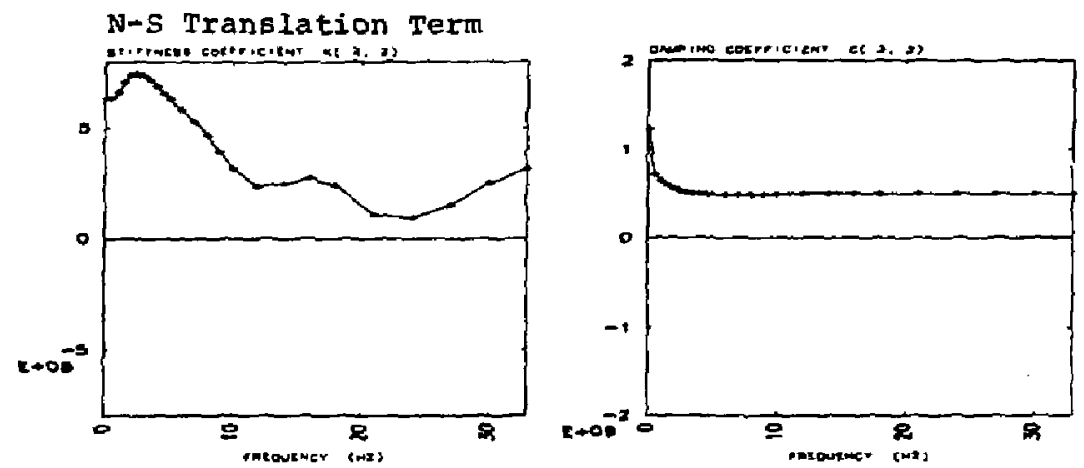

N-S Translation/Rocking Coupling Term
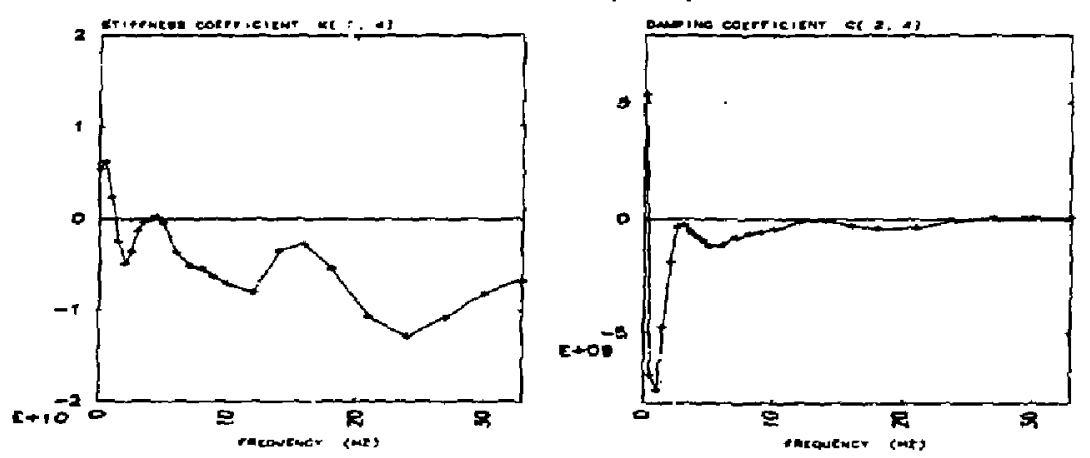

N-S Rocking Term
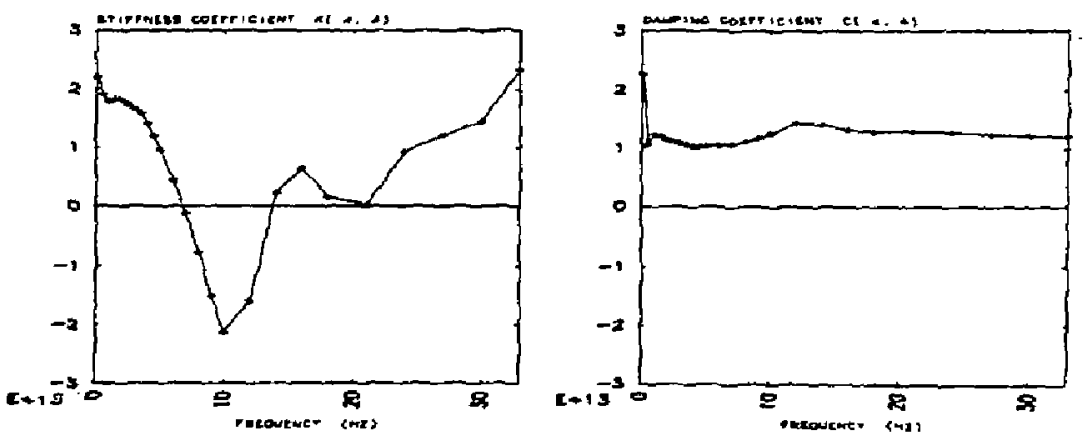

Eig. 3.3 (Continued). 

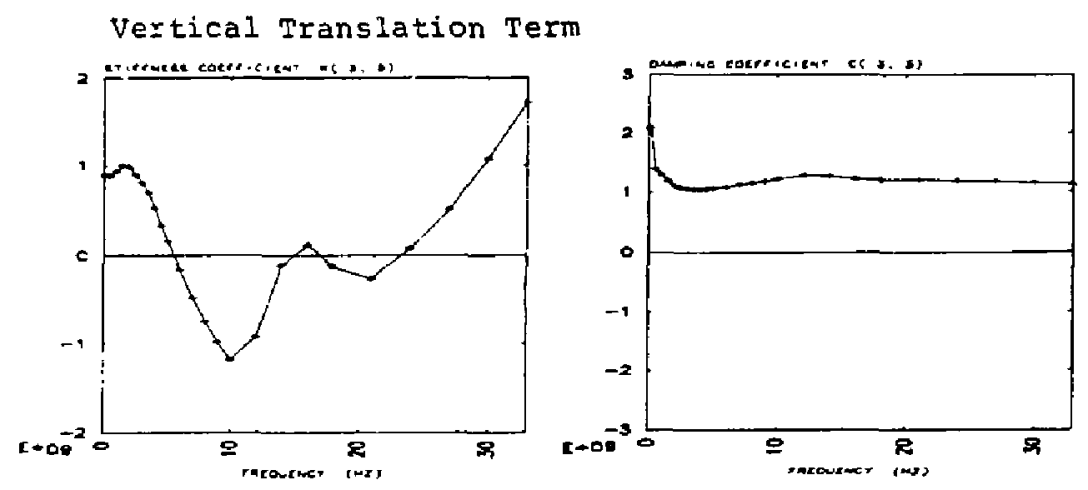

N-S Translation/Torsion Coupling Term
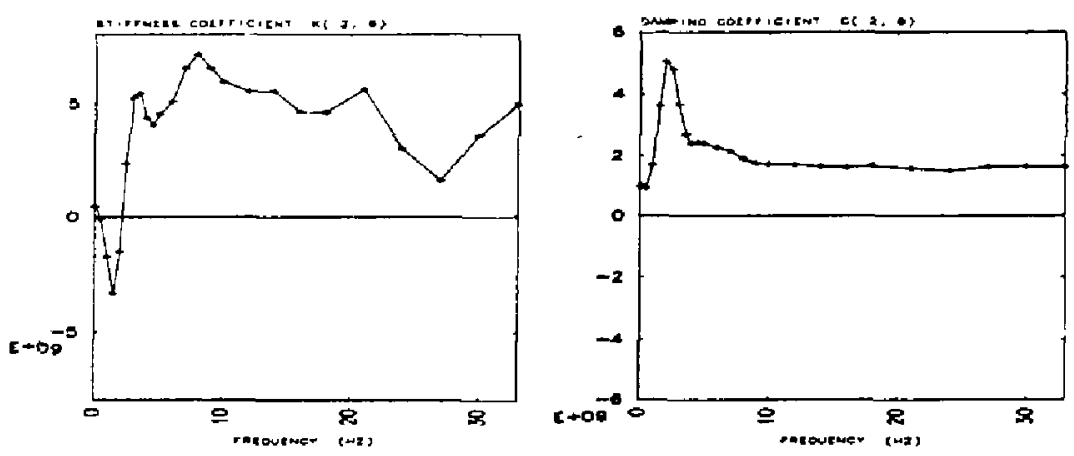

Torsional Rotation Term
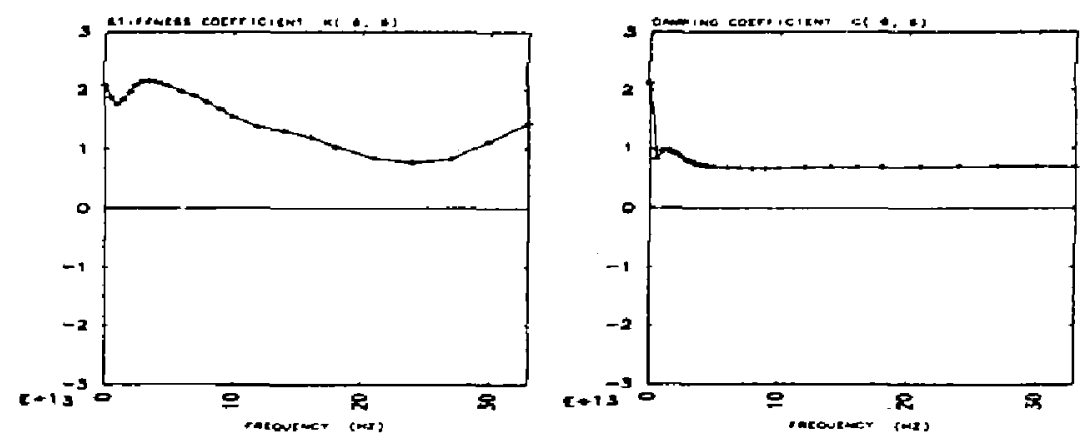

Fig. 3.3 (Continued). 

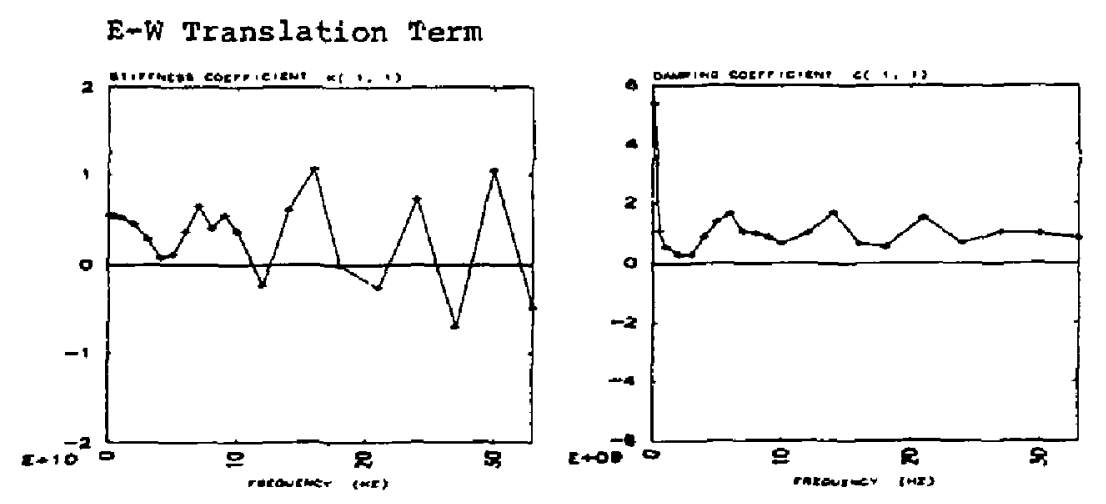

E-W Translation/Rocking Coupling Term
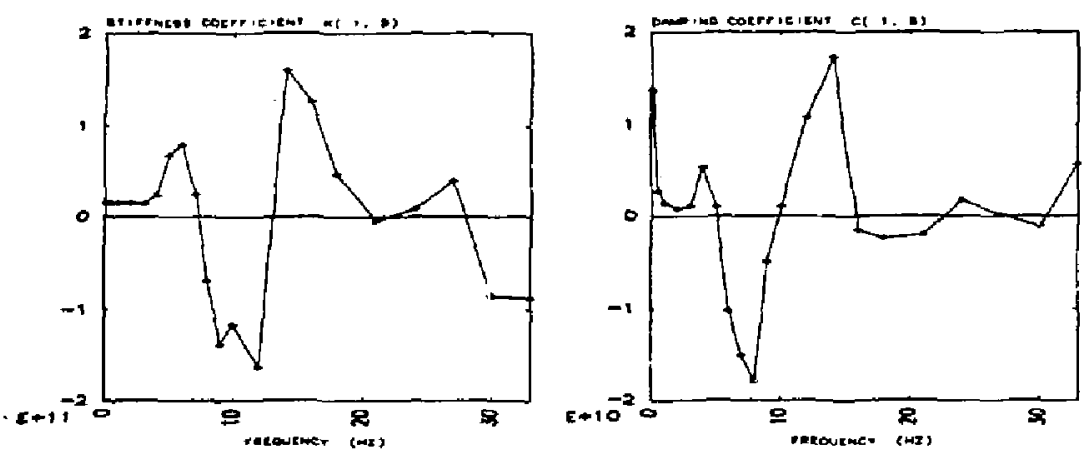

\section{E-W Rocking Term}
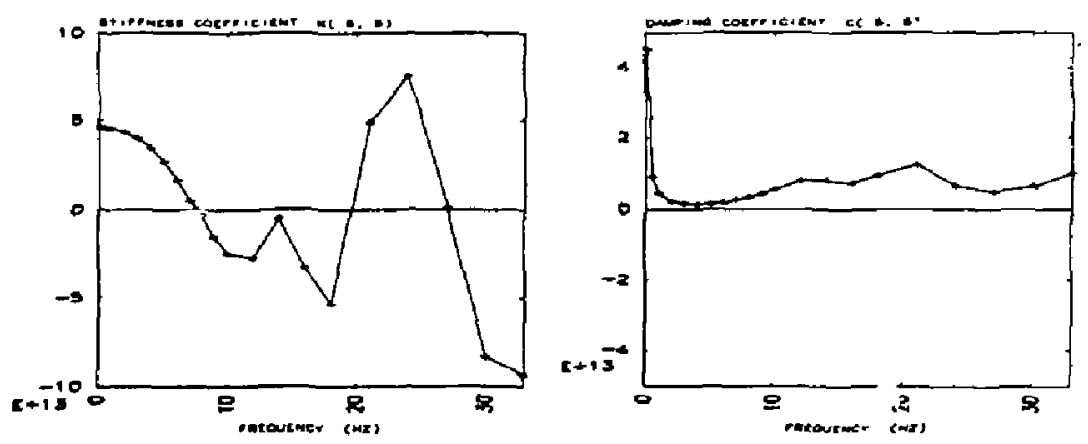

Fig. 3.4 Impedances for the $71 \mathrm{ft}$. Soil Layer over Bedrock; $V_{\mathrm{s}}=1000 \mathrm{fps}$ : Surface Foundation.

$$
\text { 3-14 }
$$



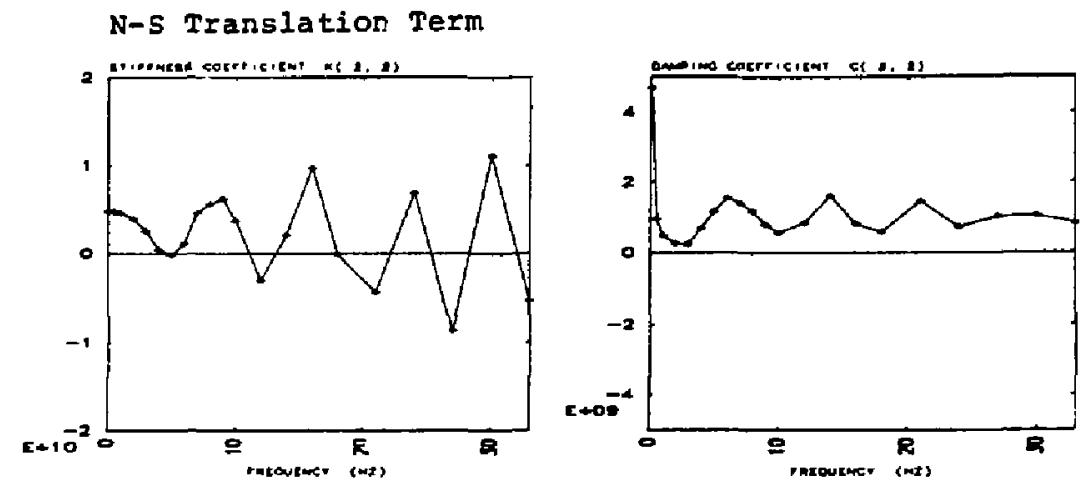

N-S Translation/Rocking Coupling Term
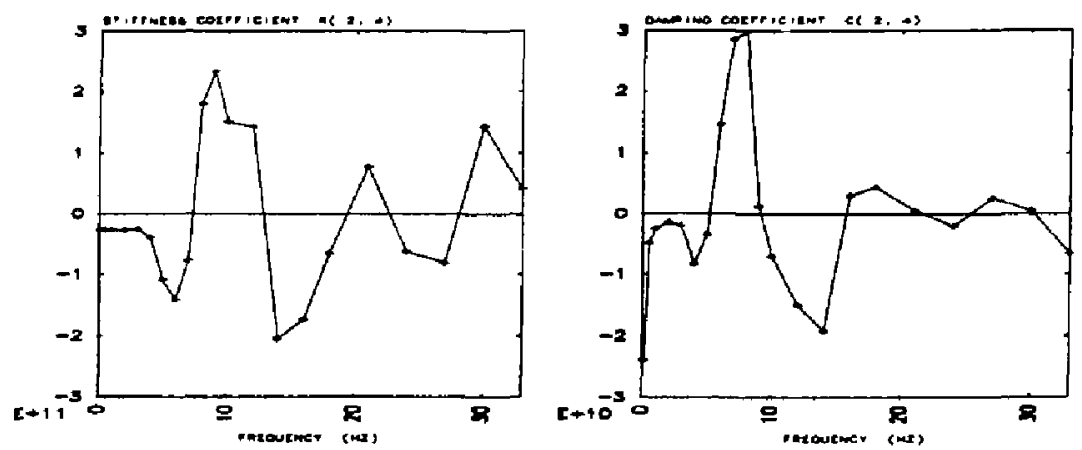

N-S Rocking Term
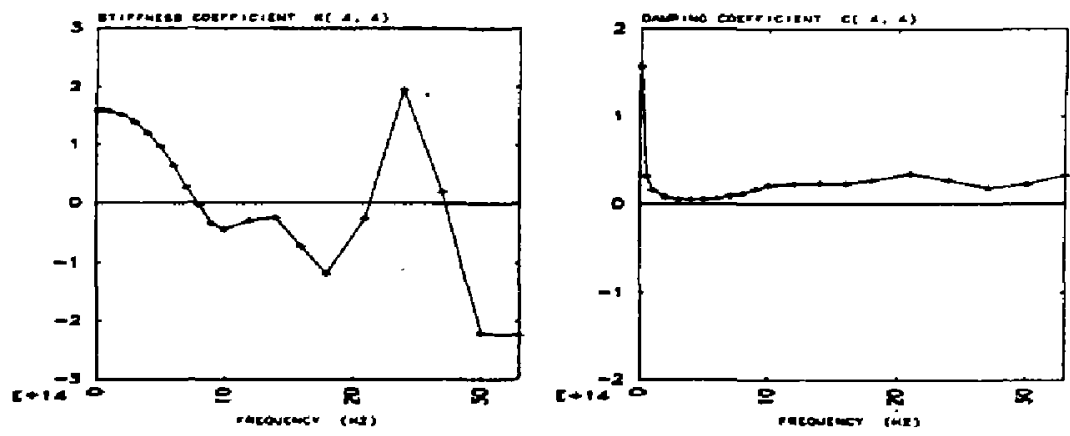

Fig. 3.4 (Continued). 

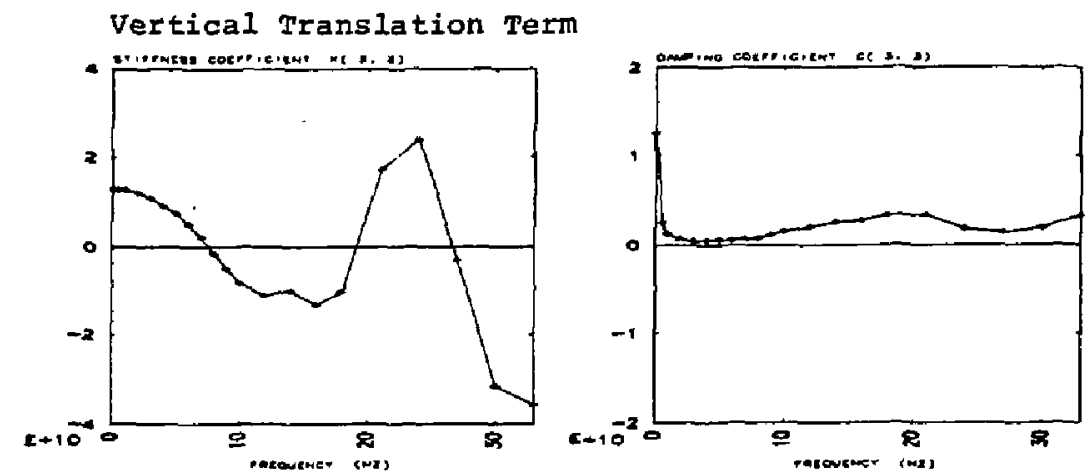

N-S Translation/Torsion Coupling Term
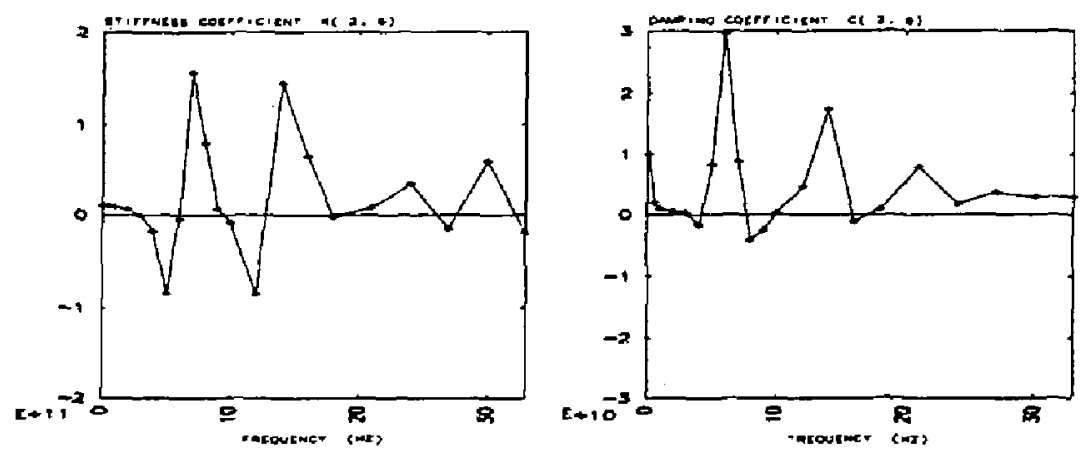

Torsional Rotation Term
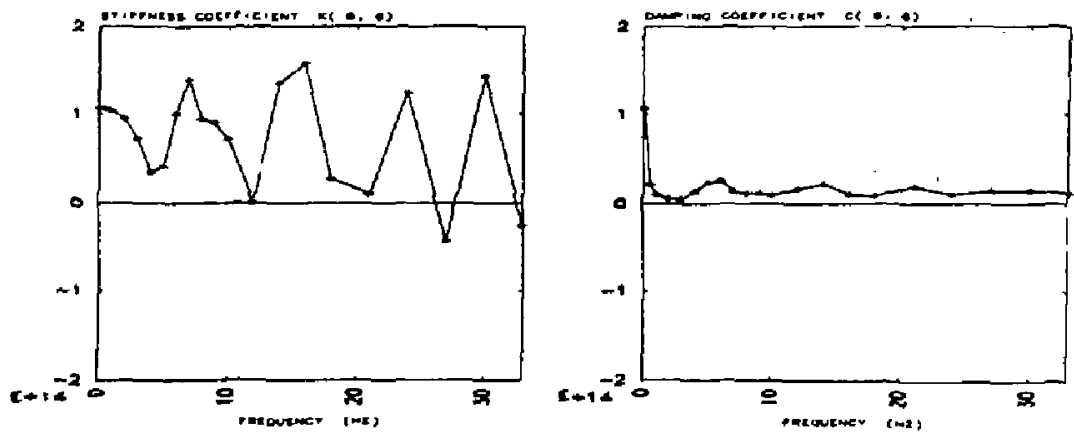

Fig. 3.4 (Continued). 
E-W Translation Term
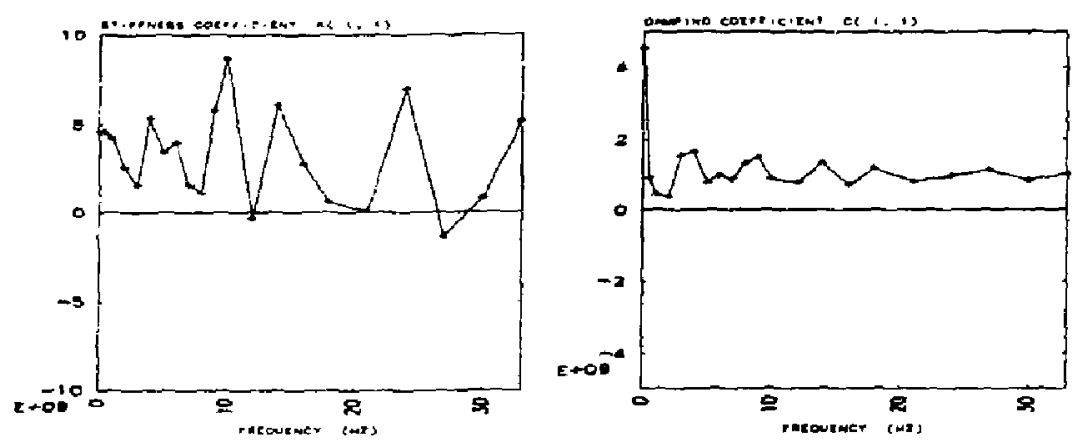

E-W Translation/Rocking Coupling Term
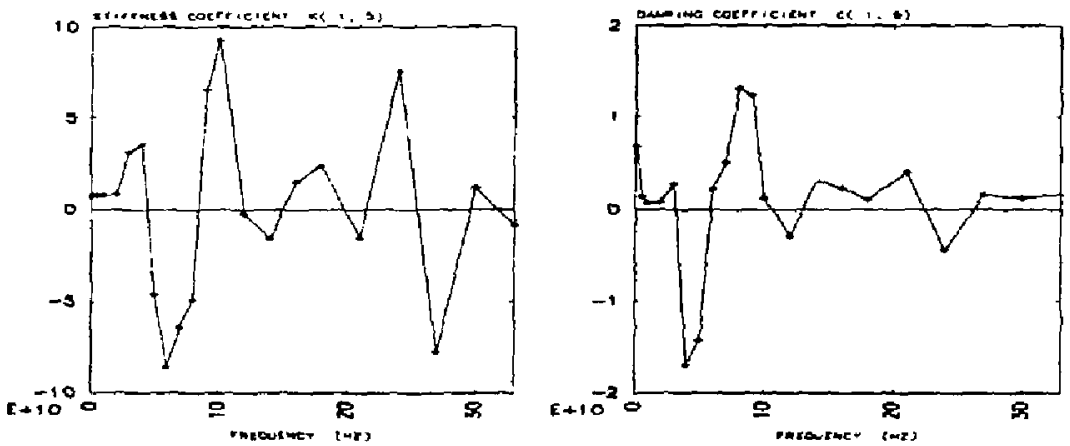

E-W Ronking Term
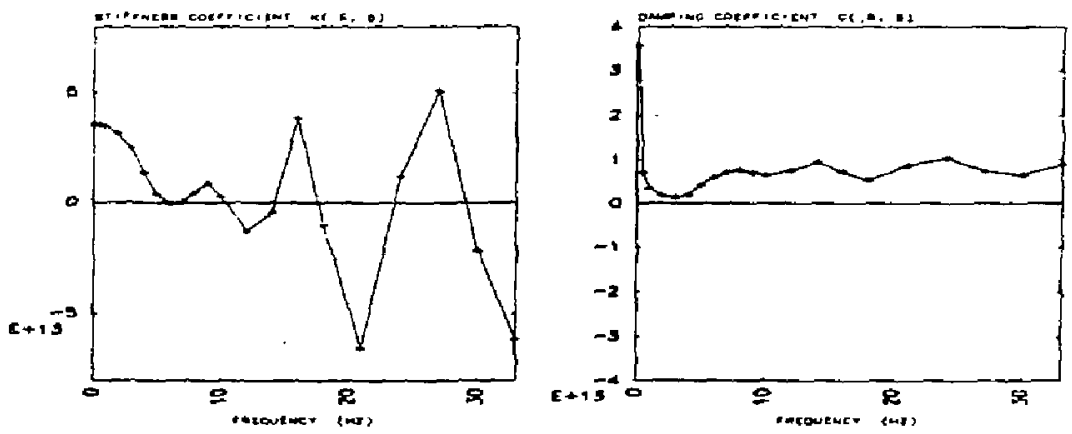

Fig. 3.5 Impedances for the $110 \mathrm{ft}$. Soil Layer over Bedrock; $v_{s}=1000 \mathrm{fps}$; Surface Foundation. 

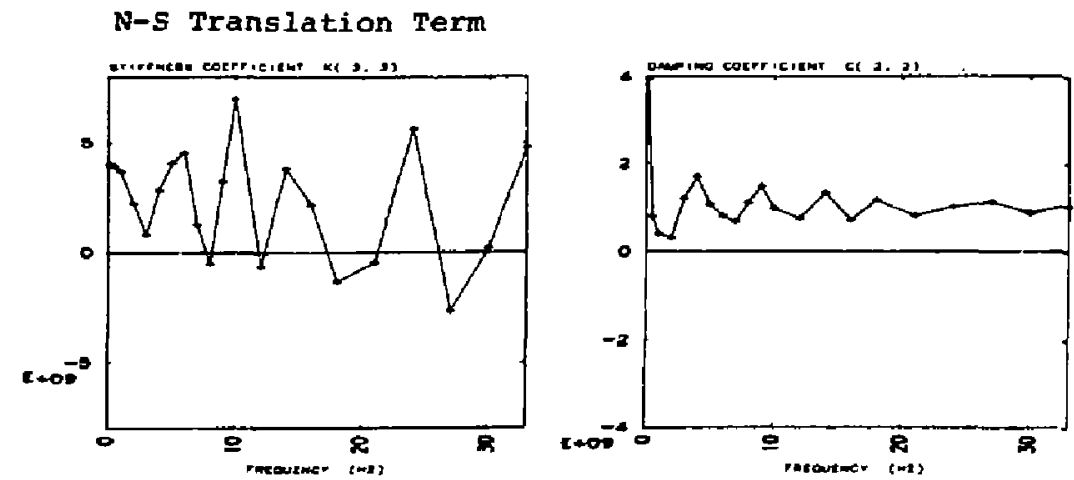

N-S Translatic ./Rocking Coupling Term
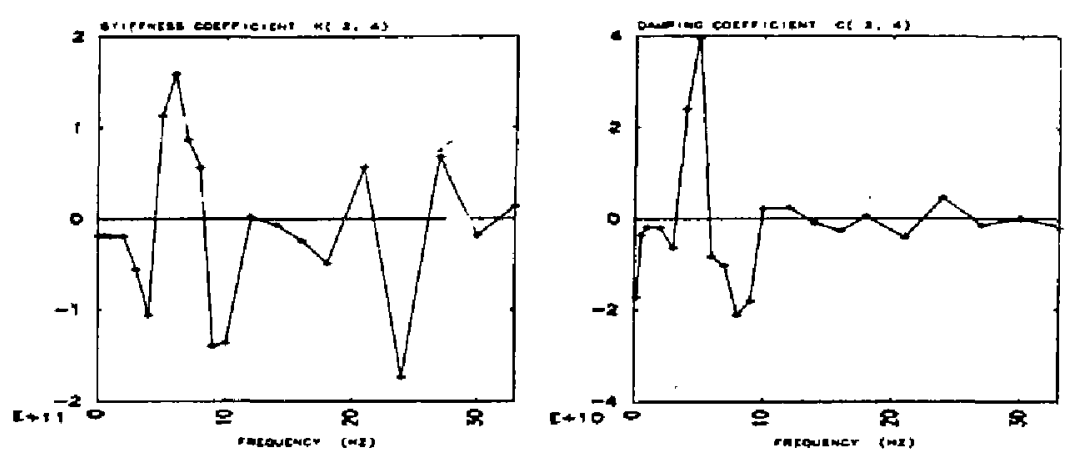

N-S Rocking Term
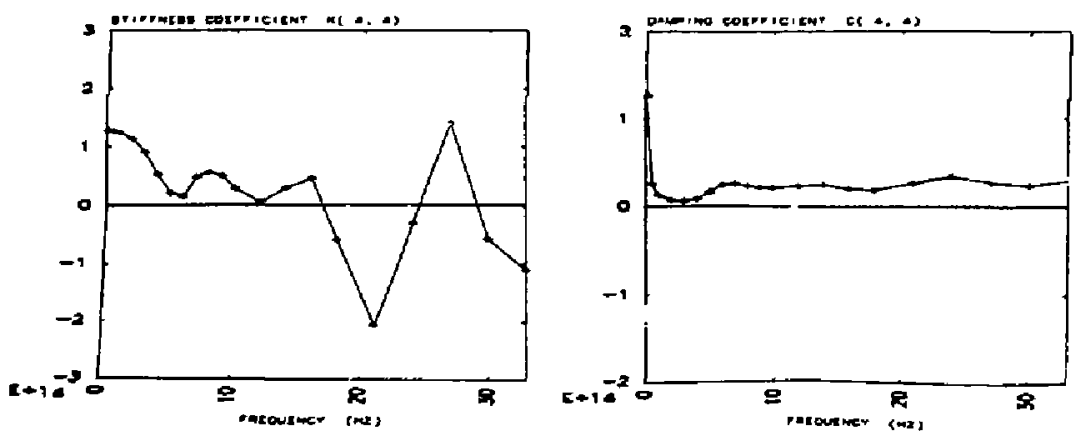

Fiq. 3.5 (Continued). 
Vertical Translation Term
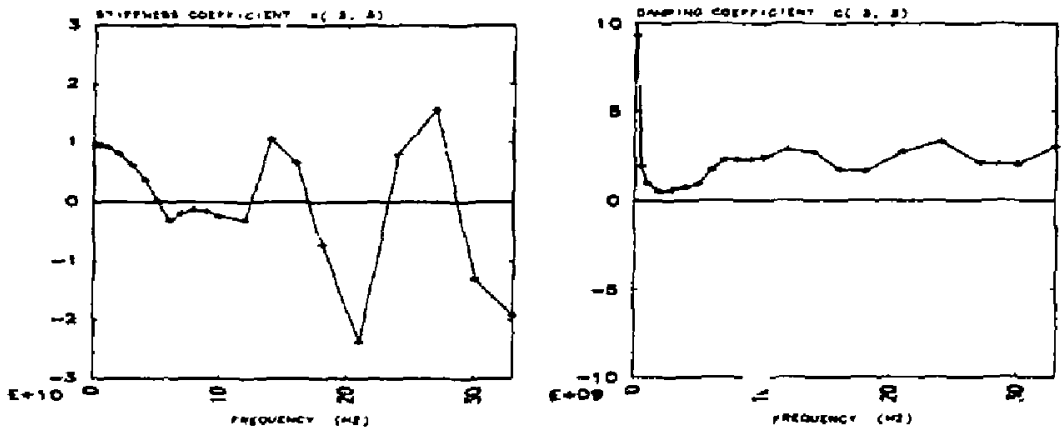

N-S Trasslation/Torsion Coupling Term
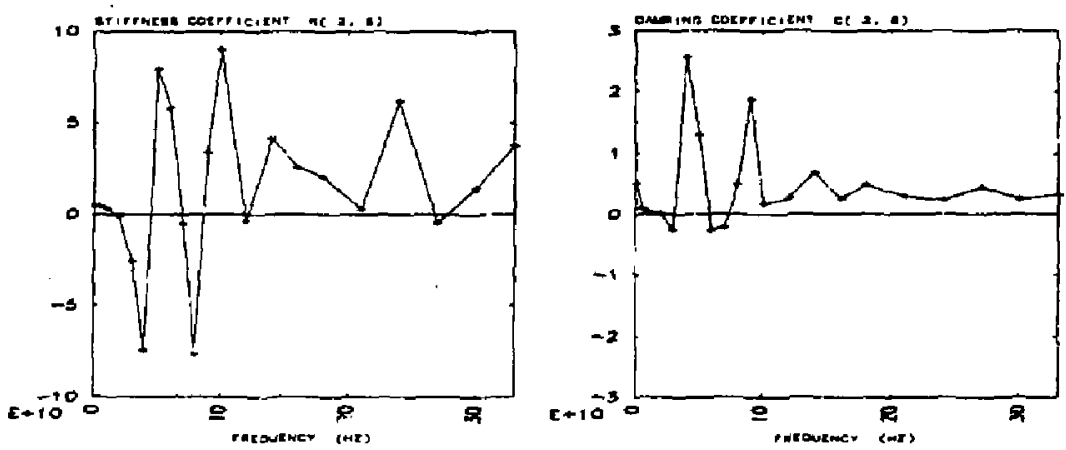

Torsional Rotation Term
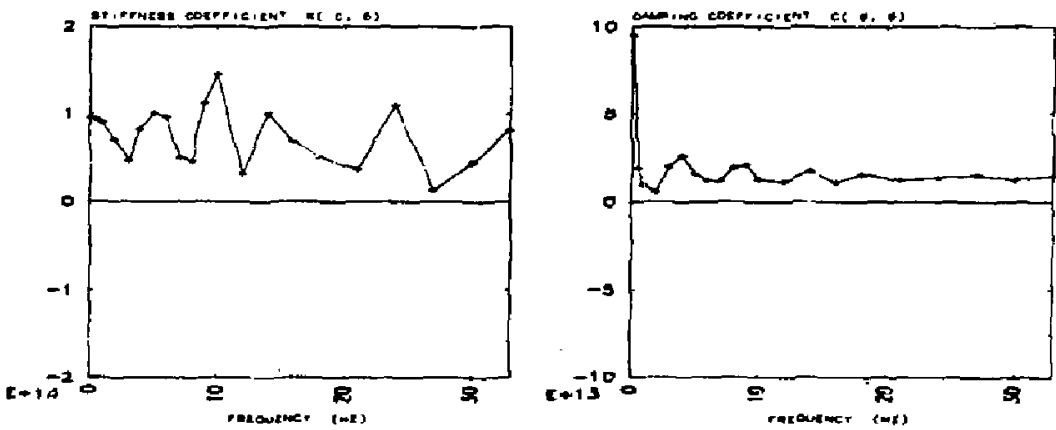

Fiq. 3.5 (Continued). 


\subsubsection{Embedded Foundation Impedances}

For those cases where the structure's foundation is assumed to be embedded, i.e. embedded in an identical manner to the Zion AFT complex, impedances and scattering matrices were developed. The surface-founded impedances form the basis for the embedded case, $i . e$. the surface-founded values were corrected for embedment. To do so, an equivalent cylinder was developed with dimensions obtained by matching the toral excavated volume and the surface area of the foundations. This results in a cyinder of equivalent radius of $112 \mathrm{ft}$. and an embedment depth of $39 \mathrm{ft}$. - and $e / \mathrm{c}^{-}$of 0.35 . Scattering matrices were generated for this equivalent cylinder and used in the analyses. The procedure to obtain corrections co the impedances for embedment was to calculate impedances for the embedded cylinder and a surface-founded circular disk of equal area founded at the same elevation as the subject structure. The correction consists of computing differences in these impedances frequency-by-frequency and adding these differences to the $T$-shaped surface impedances. This procedure corresponds to that used in the SSMRP response calculetions (Ref. 3).

Figures 3.6 and 3.7 display embedded impedances for the uniform half-space, $v_{s}=500 \mathrm{fps}$, and the $110 \mathrm{ft}$. layer, $v_{s}=$ 1000 fps, cases, respectively. 

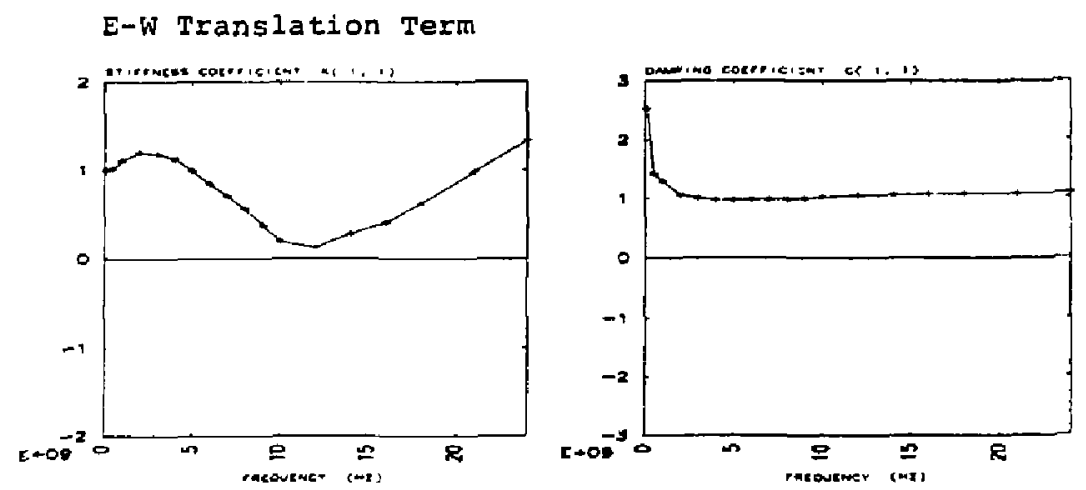

E-W Translation/Rocking Coupling Term
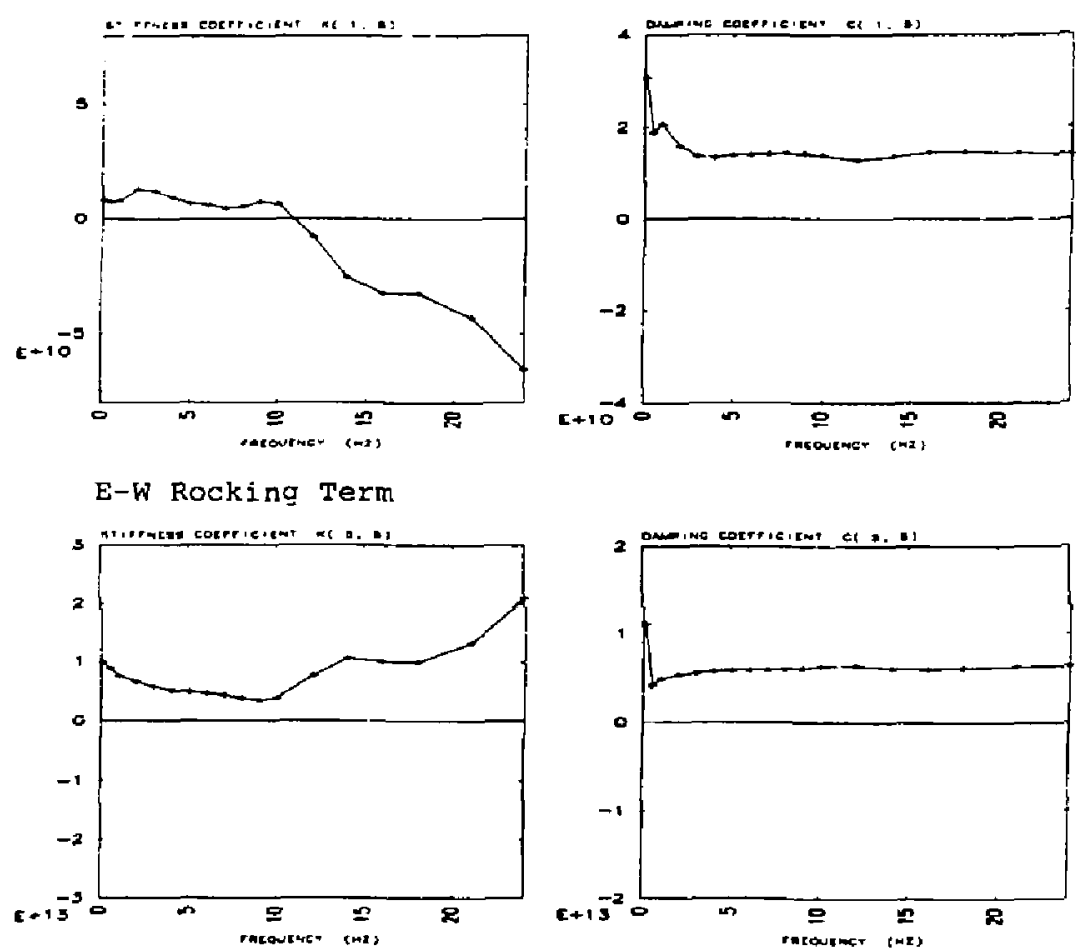

Fig. 3.6 Impedances for the Uniform Half-Space; $V_{s}=500 \mathrm{fps}_{\mathrm{p}}$; Embedded Foundation.

$$
3-21
$$



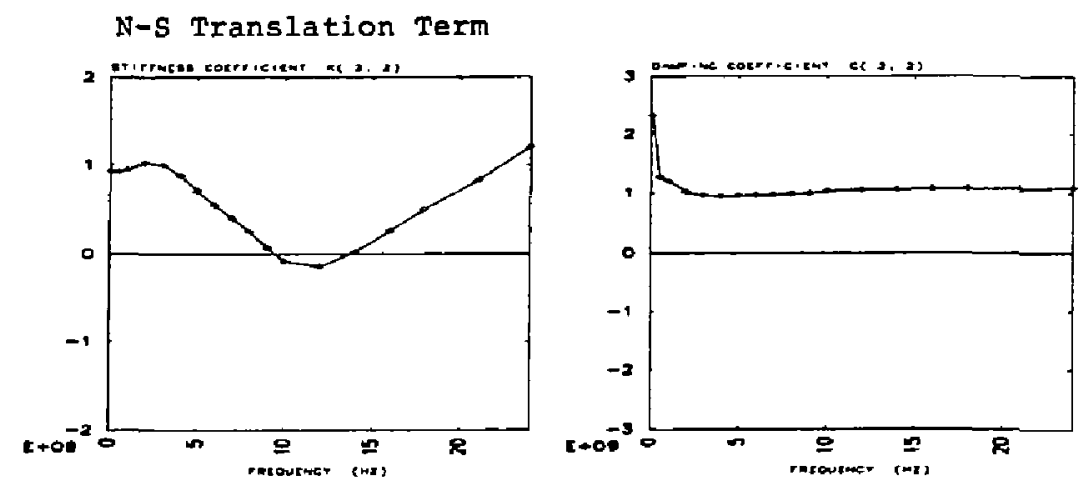

N-S Translation/Rocking Coupling Term
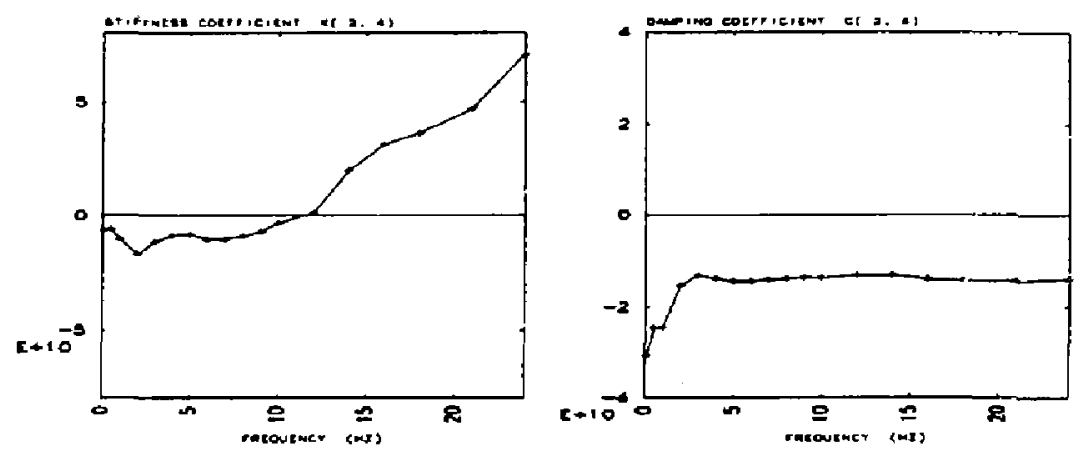

N-S Rocking Term
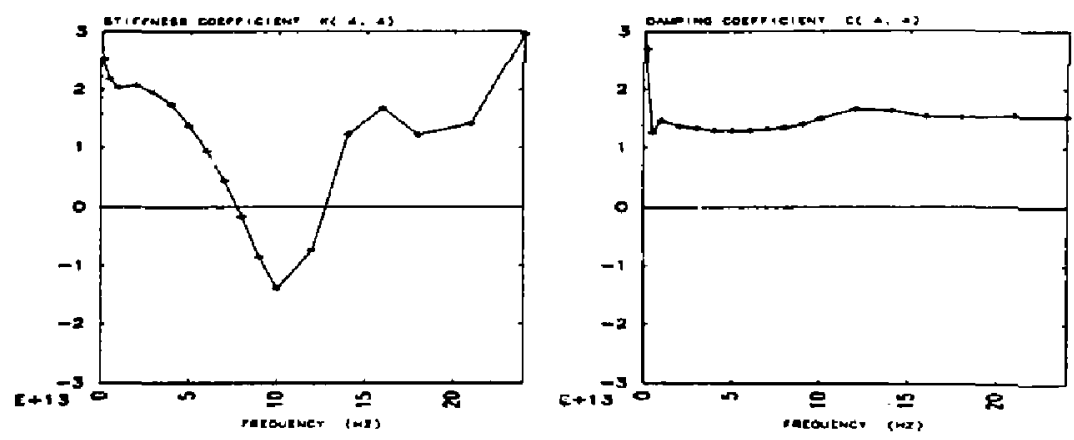

Fig. 3.6 (Continued). 

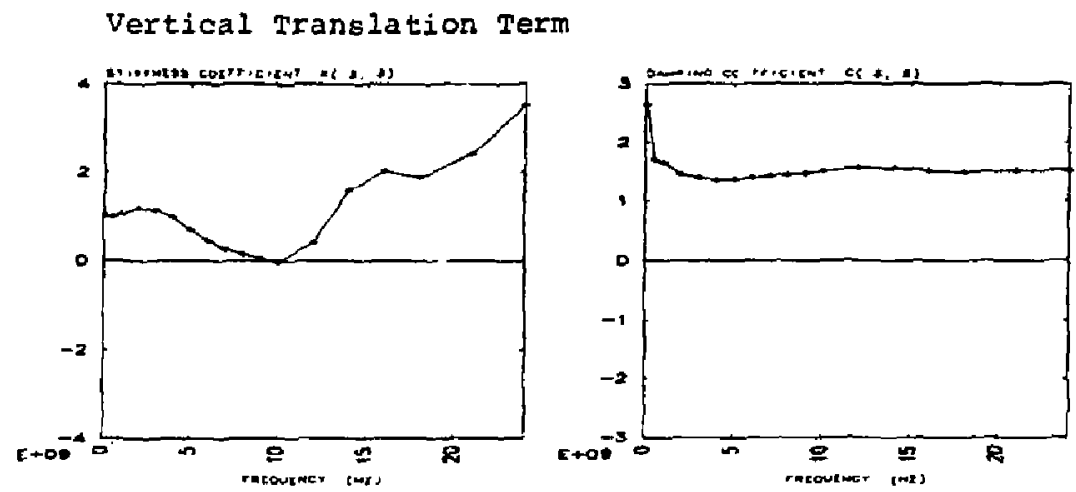

N-S Translation/Torsion Coupling Term
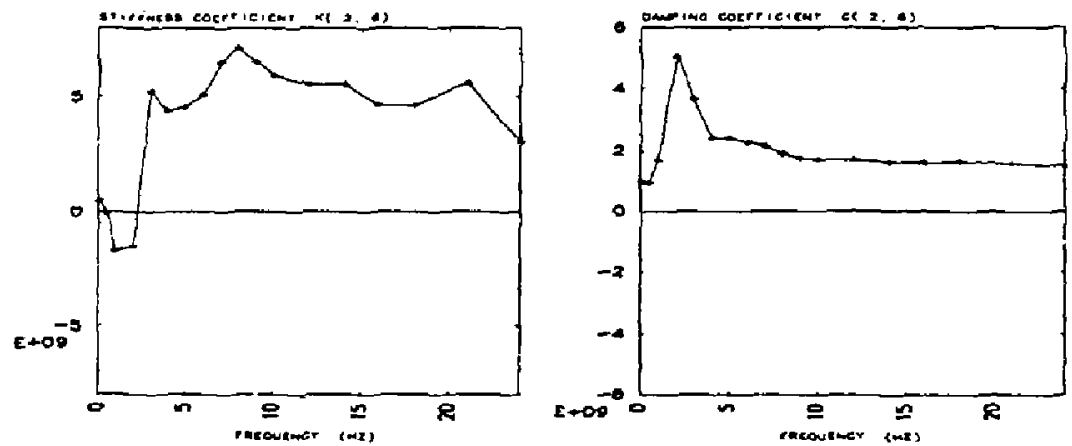

Torsional Rotation Term
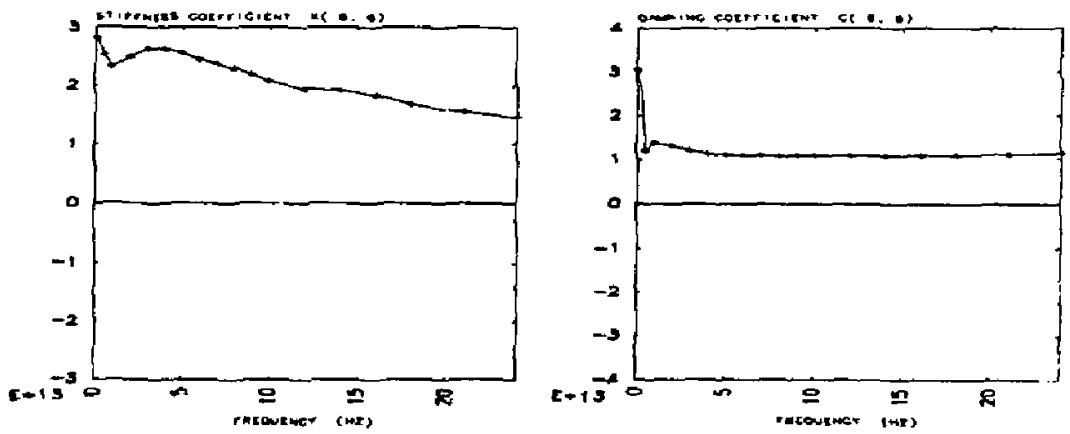

Fig. 3.6 (Continued). 
-W Translation Term
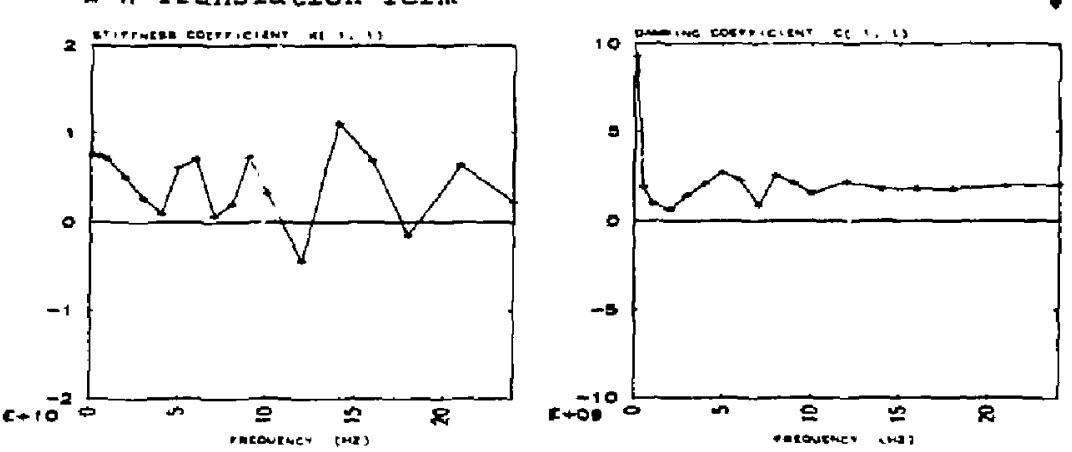

E-W Transletion/Rocking Coupling Term
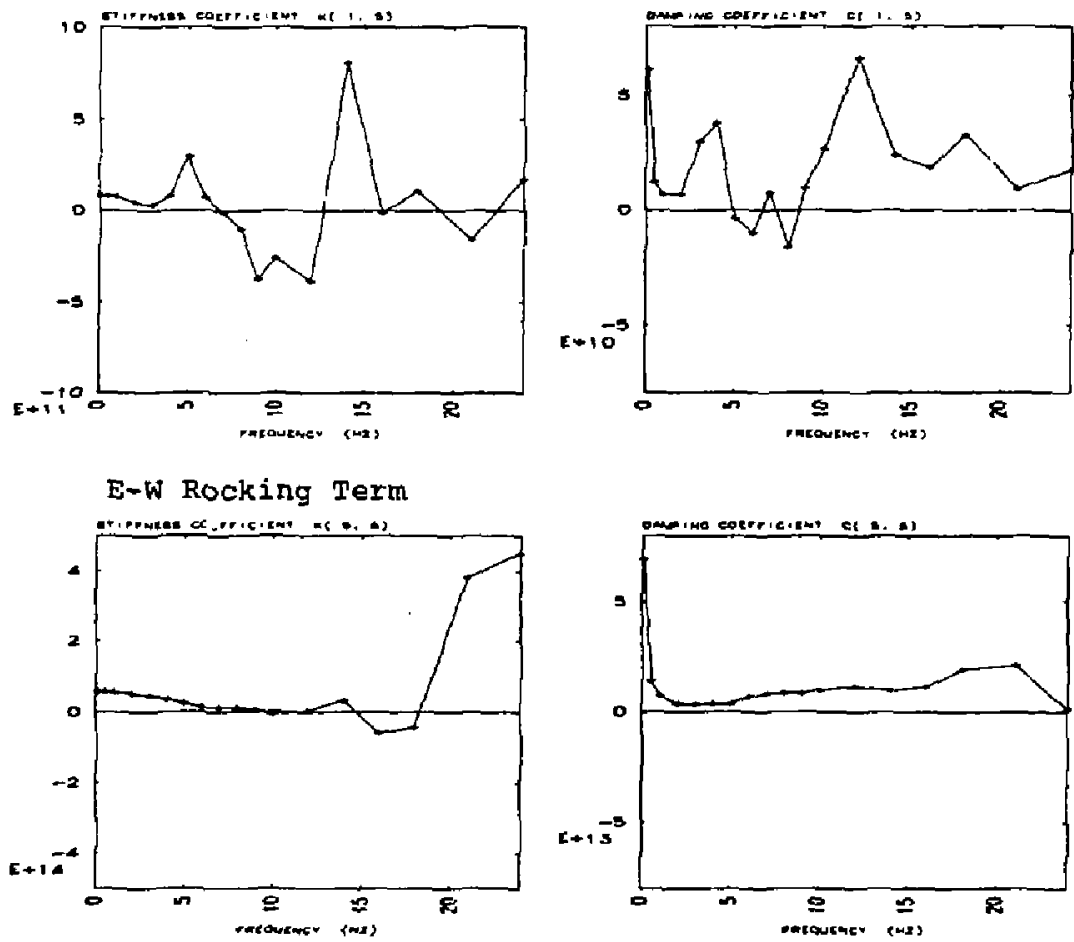

Fig. 3.7 Impedances for the $110 \mathrm{ft}$. Soil Layer over Bedrock; $v_{s}=1000$ fps; Embedded Foundation. 

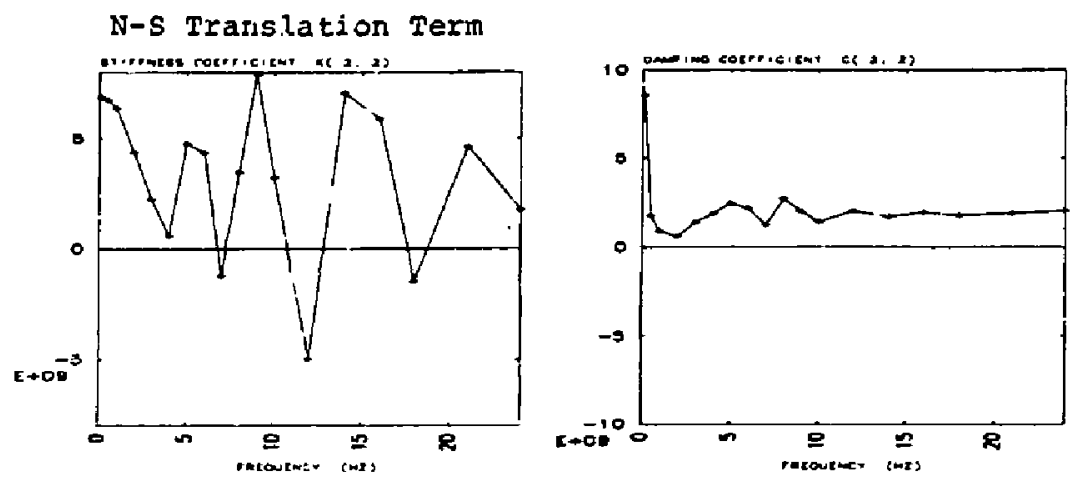

N-S Translation/Rocking Coupling Term
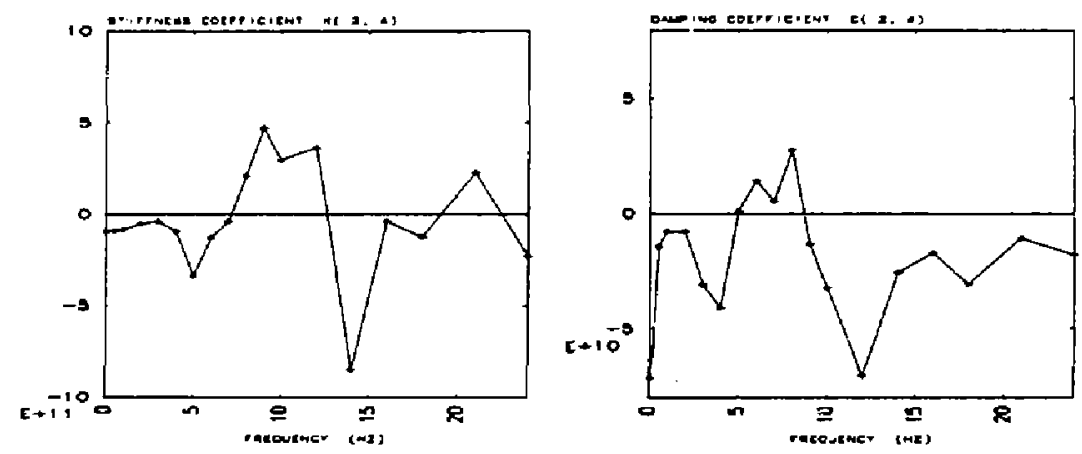

N-S Rocking Term
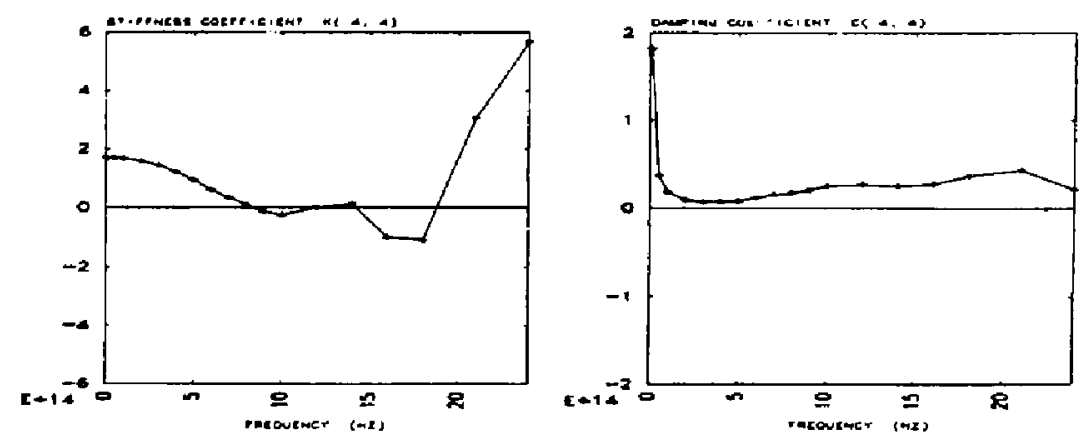

Fig. 3.7 (Continued). 

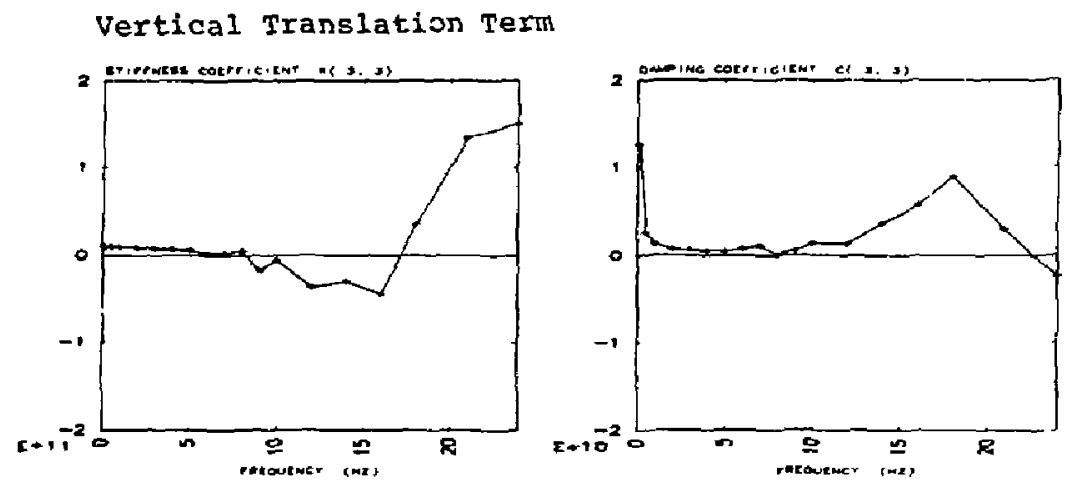

N-S Translation/Torsion Coupling Term
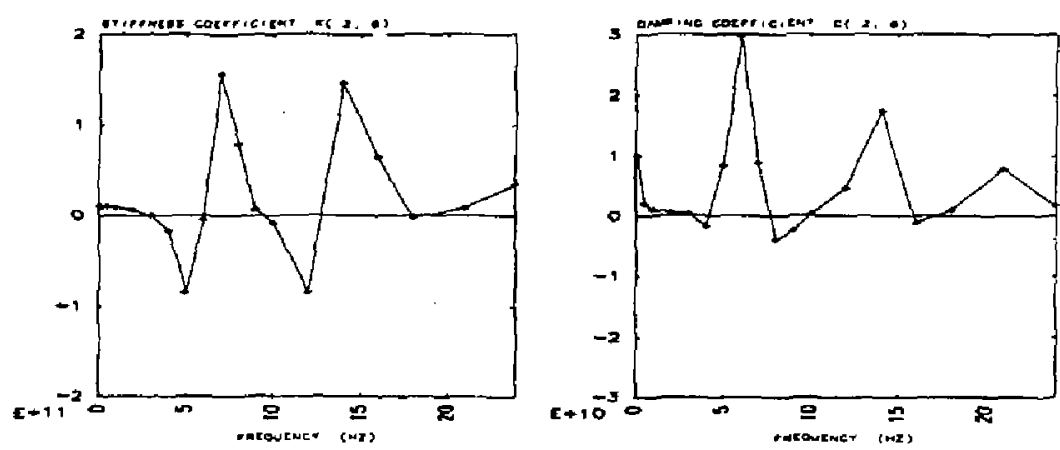

Torsional Rotation Term
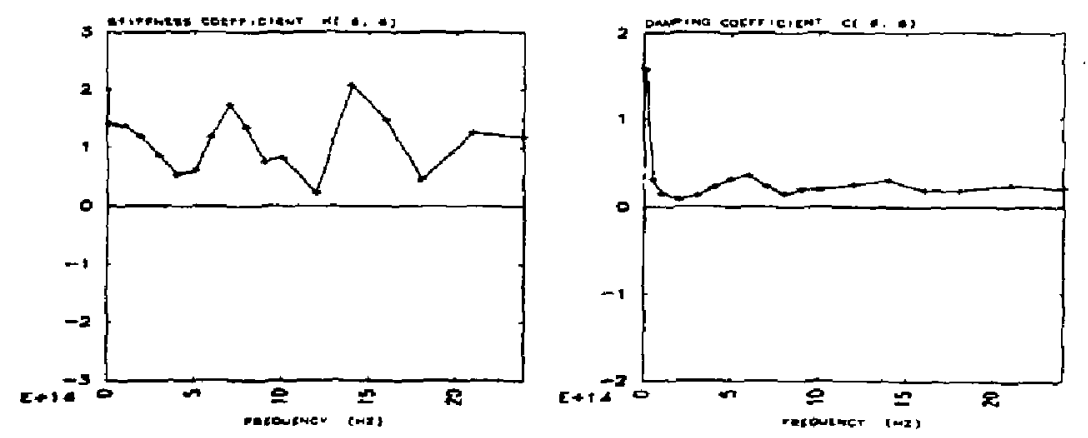

Fig. 3.7 (Continued). 


\subsubsection{Frequency Independent Impedances}

One simplification investigated in the present study was to develop constant frequency independent soil springs which represent force displacement characteristics of the soil. The soil stiffness was represented by six spring constants, thiee translational and three rotational, reprcsenting the diagonal terms of the impedance matrix. The spring constants are calculated for an equivalent, rigid circular footing resting on an elastic half-space, as described in Ref. 5. For the translational springs, the circular plan was selected to yield a surface area equal to that of the actual $\mathrm{T}$-shaped foundation. The circular footings for the rotational spring constants were chosen to preserve the rotational inertia of the $T$-shaped foundation for north-south and east-west rocking and torsion. Table 3.1 sumarizes the spring constants for the six foundation degrees-of-freedom. The same four uniform half-spaces discussed earlier were treated here. 
Table 3.1 Linear Frequency Independent Impedances for Uniform Half-Spaces.

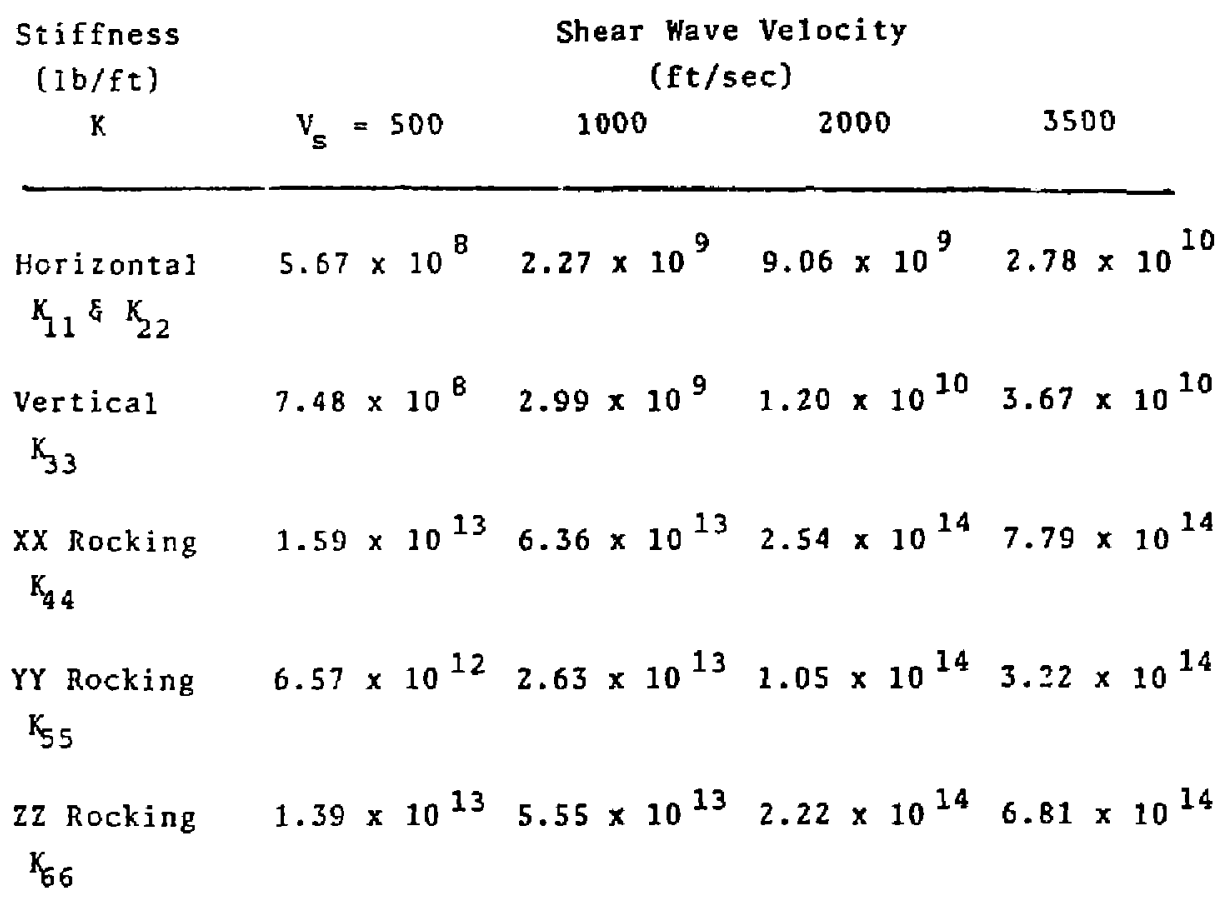


The dynamic characteristics of the structure were represented by its fixed-base eigensystem. In all, eighty modes were extracted and used. Table 3.2 shows the eighty modes -frequencies and percent modal masses. Table 3.3 further highlights significant modej. As noted from Table 3.2, the total mass farticipating in the eighty modes was 83.8 in the north-south firection, $B 3.8 \%$ in the east-west direction, and 71.9 in the vertical direction. To account for this non-participating mase, a "missing-mass" correction was applied.

The correction procedure involves performing a static analysis of the structure, apflying load vectors consisting of the portion of the nodal masses not included in the dynamic analysis. Six load vectors are applied; one for each of the six foundation degrees-of-freedom. The resulting element stresses become influence coefficients relating element stresses to fouzdation acceleration. Element stress influence coefficients are combined to determine influence coefficients for axial force, in-plane shear, and overturning moment. These influence coefficients are applied to the six acceleration time histories of the foundation and then added by direct superposition to the dynamic response. All results presented here include corrections for modal truncation or "missing mass." 
Table 3.2 Percent of Total Mass Participating in each Mode.

\begin{tabular}{|c|c|c|c|c|c|c|c|c|c|}
\hline MOOE & RAC ISEC & $H \bar{z}$ & DAMPINS & $x-\cos$ & $Y-\operatorname{COM} P$ & $Z$-COHF & $x x-7.04 p$ & $44-\cot ^{2}$ & $2 \%-\operatorname{COM}^{\circ}$ \\
\hline 1 & $1: .907$ & 1.895 & 0.0400 & 0.0 & 0.0 & 0.8 & 0.0 & 1.8 & $0 .=$ \\
\hline 2 & 17.456 & 2.790 & 0.0400 & 0.0 & 0.0 & D. 0 & D. C & o : & c. $c$ \\
\hline 3 & 30.301 & 4.775 & 0.0400 & 0.0 & 0.0 & 0,1 & 0.0 & 0.5 & 0.0 \\
\hline 4 & 33.819 & 5.302 & 0.0400 & 0.0 & 0.2 & 0.0 & 0.2 & 0.0 & 0. 3 \\
\hline 5 & 36.039 & 6.054 & 0.0400 & 0.0 & 0.0 & 0.0 & 0. 0 & 0.0 & ¿ 0 \\
\hline 6 & 40.538 & 6.452 & 0.0400 & 1.2 & 0.0 & 0.0 & 0.0 & 1.0 & 0.0 \\
\hline 7 & 43.240 & 5.882 & 0.0400 & 0.0 & 0.0 & 0.2 & 0.0 & 0.6 & 0.0 \\
\hline 日 & 49.017 & 7.801 & 0.0400 & 0.0 & 0.0 & 0.0 & 0.0 & 0.0 & 0.0 \\
\hline 9 & 59.113 & 9.408 & 0.0400 & 1.9 & 0.0 & 0.0 & o. 0 & 1.3 & 0.0 \\
\hline 10 & 59.649 & 9.493 & 0.0400 & 50.6 & 0.0 & 0.8 & c. 0 & 42.9 & D. 0 \\
\hline 11 & 61.364 & 9.766 & 0.0400 & 0.2 & 8.0 & 0.0 & 0.0 & 0.2 & D. \\
\hline 12 & 63.262 & 10.068 & 0.0400 & 0.0 & 13.1 & 0.0 & 11.6 & 0.0 & ह1: \\
\hline 13 & 67.423 & 10.731 & 0.0400 & 0.1 & $0 . c$ & 0.0 & 0.0 & 0.3 & $0=$ \\
\hline 14 & 72.570 & $1: .550$ & 0.0400 & 0.0 & 0.3 & 0.0 & 0.0 & 0.0 & $5 e$ \\
\hline 15 & 73.062 & $11.6 \geqslant 0$ & L. 0400 & 0.0 & 2.3 & 0.0 & 1.1 & 0.5 & $13 E$ \\
\hline 16 & 74.117 & 11.795 & $0.040 \mathrm{~L}$ & 0.0 & 9.3 & 0.0 & 5.0 & 0.0 & 92 \\
\hline 17 & 74.973 & $11.93 z$ & 0.0402 & 0.0 & 0.0 & 0.0 & 0.0 & 0.0 & C.c \\
\hline 18 & 75.085 & 11.950 & 0.0400 & 0.0 & 0.0 & 0.0 & 0.0 & 0.0 & ec \\
\hline 19 & 90.136 & 12.754 & 0.0400 & 0.0 & 0.0 & 0.0 & 0.0 & 0.1 & 00 \\
\hline 20 & 80.616 & 12.830 & 0.0400 & 0.0 & 29.5 & 0.0 & 17.1 & 0.0 & D. C \\
\hline 21 & 81.227 & 12.920 & 0.0400 & 1.7 & 0.0 & 0.1 & 0.0 & 3.2 & $0=$ \\
\hline 22 & 82.174 & 13.078 & 0.0400 & 0.0 & 1.4 & 0.0 & 0.9 & 0.0 & G. \\
\hline 23 & 86.031 & 13.692 & 0.0400 & 0.0 & 0.6 & 0.0 & 0.3 & 0.0 & $0:$ \\
\hline 34 & 93.373 & 14.851 & 0.0400 & 0.0 & 0.1 & 0.0 & 0.0 & 0.0 & 03 \\
\hline 25 & 97.823 & 35.569 & 0.0400 & 0.0 & 1.1 & 0.0 & 0.9 & 0.0 & $0 . z$ \\
\hline 26 & 98.674 & 15.705 & 0.0400 & 5.8 & 0.0 & 19.5 & 0.0 & 0.6 & 0.3 \\
\hline $2^{7}$ & 99.818 & 15.986 & 0.0400 & 0.0 & 0.6 & 0.0 & 0.0 & 0.0 & E. \\
\hline 28 & 102.412 & 16.299 & 0.0400 & 0.0 & 0.0 & 0.0 & 0.1 & C. C & $\therefore . c$ \\
\hline 29 & 105.369 & 16.730 & 0.0400 & 0.8 & 0.0 & E. 1 & 0.0 & c. 6 & $c c$ \\
\hline 30 & 110.426 & 17.575 & 0.0400 & 2.7 & 0.0 & 7.6 & o.. & 2.2 & $0 . t$ \\
\hline 31 & 110.664 & 17.613 & 0.0400 & 0.0 & 0.0 & 0.0 & 0.4 & 0.0 & 1.5 \\
\hline $3 \hat{2}$ & 112 E6E & 17.035 & 0.0400 & 0.2 & 0.0 & D.9 & 0.0 & $0 . i$ & ce \\
\hline 33 & 112.300 & 17.873 & $0.040 D$ & 0.0 & 0.2 & 0.0 & 6.4 & 0.0 & {$[\equiv$} \\
\hline 34 & 114.614 & $18.2+i$ & 0.0400 & 1.9 & 0.0 & $1 . \vec{z}$ & 0.0 & 01 & $c c$ \\
\hline 35 & 116.282 & 10.507 & 0.0400 & 0.7 & 0.0 & 0.4 & 0.0 & 0.0 & f. $:$ \\
\hline 36 & 117.548 & 18.700 & 0.0400 & 0.1 & 0.0 & 1.4 & 0.0 & 0.6 & $c=$ \\
\hline 37 & 120.393 & 19.161 & 0.0400 & a.o & 4.2 & 0.0 & 3.0 & 0.0 & ह 9 \\
\hline 36 & 121.041 & 19254 & 0.0400 & 0.0 & 0.0 & 0.0 & 0.0 & 0.0 & is \\
\hline 39 & 125.339 & 19.948 & 0.0400 & 0.8 & 0.0 & a. 1 & D.D & 5.5 & $0 \mathrm{i}$ \\
\hline 40 & 125,980 & 20.052 & 0.0400 & 0.0 & 0.0 & o. 0 & 2.5 & 0.0 & $0=$ \\
\hline 41 & 125.559 & 20. 15日 & 0.0400 & 1.2 & 0.0 & 3.3 & 0.0 & 0.3 & G : \\
\hline $4 \overrightarrow{2}$ & 127.349 & 20.258 & D 0400 & 0.0 & 0.7 & 0.0 & 17 & D. $\Gamma$ & 25 \\
\hline 43 & 130.247 & 20.729 & 0.0400 & 4.1 & 0.0 & 0.1 & $0 . c$ & $0 . \overline{2}$ & $2:$ \\
\hline 44 & 135.754 & 21.606 & 0.0400 & 0.0 & 0.0 & 0.0 & 0.0 & 0.0 & Co \\
\hline 45 & 135.577 & 21.737 & 0.0400 & 0.0 & 0.1 & 0.0 & 0.0 & $\mathfrak{c}, 0$ & $\equiv 6$ \\
\hline 45 & 137.125 & 2]. Bet4 & 0.0400 & 1,4 & 0.0 & 0.3 & 0.0 & 0.2 & $=c$ \\
\hline 47 & 139.252 & 22.163 & 0.0400 & 0.0 & 0.5 & 00 & 1.0 & c 0 & $\bar{E}=$ \\
\hline 48 & 141.849 & 22.576 & 0.0400 & 1.6 & D. D & 0.0 & 0.0 & 1.7 & $0:$ \\
\hline 49 & 143.052 & 2.2 .759 & 0.0400 & 0.0 & 0.0 & 0.0 & 0.3 & 0.0 & $c=$ \\
\hline 50 & 145.504 & c3.158 & 0.0400 & 0.0 & 0.5 & 0.0 & 0.1 & a. 0 & 0.3 \\
\hline 51 & 146.913 & 23.362 & 0.0400 & 0.5 & 0.0 & 5.5 & 0.0 & 0.2 & 0.0 \\
\hline 52 & 148.083 & $23 \leq 6 B$ & 0.0400 & 0.0 & 0.1 & 0.0 & 5.7 & 00 & OE \\
\hline 53 & 148.433 & 23.624 & 0.0400 & 1.3 & 0.0 & 0.6 & $0 . D$ & 0.0 & 0.0 \\
\hline 54 & 148.943 & 23. 705 & 0.0400 & 0.0 & 0.3 & 0.0 & i.e & 0.0 & 06 \\
\hline 55 & $151-167$ & 24.059 & 0.0400 & 0.1 & 0.0 & 40 & 0.0 & I. & 0.0 \\
\hline
\end{tabular}




\begin{tabular}{|c|c|c|c|}
\hline 56 & 153.106 & 24.380 & 0 ОчОО \\
\hline 57 & 154.716 & 24.624 & 0.0405 \\
\hline 58 & ר. ב55. & 24.712 & 0.0400 \\
\hline 59 & 155.515 & 24.751 & 0.0400 \\
\hline 50 & 156.899 & 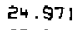 & 0.0400 \\
\hline 51 & 150.451 & ट5.21日 & 0.0400 \\
\hline 52 & 155.658 & 25,410 & 0.0400 \\
\hline 53 & 160,702 & 25.575 & 2.0400 \\
\hline 54 & 166.194 & 25.655 & 0.0400 \\
\hline 65 & 161.432 & 25.693 & 0.0400 \\
\hline$E E$ & IES. 6ET & Z5. 052 & 0.000 \\
\hline$E 7$ & 165.239 & 26. 299 & D. \\
\hline E日 & 165.399 & 26.324 & 0.0400 \\
\hline 69 & $165 \cdot 380$ & 26.480 & $0 . J=0$ \\
\hline 70 & 168.178 & 26.755 & 0.0400 \\
\hline 71 & $168.72^{4}$ & 25. 953 & 0.0400 \\
\hline 72 & $169.27+$ & 25.941 & 0.0408 \\
\hline 73 & 170.337 & 27.110 & 0.0400 \\
\hline 74 & 170.823 & 27.187 & 0.0400 \\
\hline 75 & $17 ! .906$ & 27. 352 & 0.0400 \\
\hline 76 & 173.263 & 23.576 & D D४DD \\
\hline 77 & 176.602 & 28.107 & D. 0400 \\
\hline 78 & 177.502 & 2日.250 & 0.5400 \\
\hline 79 & רדס. & $2 \theta .34$ 己 & 0.0400 \\
\hline 8D & 179.209 & 2日.52ᄅ & 0.0400 \\
\hline
\end{tabular}

$\begin{array}{lll}0.7 & 0.0 & 0.6 \\ 0.0 & 1.1 & 0.0 \\ 0.0 & 0.2 & 0.0 \\ 0.0 & 0.0 & 3.5 \\ 1.4 & 0.0 & 0.0 \\ 0.0 & 9.2 & 0.0 \\ 0.0 & 0.5 & 0.0 \\ 1.2 & 0.0 & 6.3 \\ 0.0 & 2.6 & 0.1 \\ 0.1 & 0.0 & 4.0 \\ 0.0 & 0.3 & 0.0 \\ 0.0 & 0.0 & 0.5 \\ 0.0 & 0.1 & 0.0 \\ 0.4 & 0.0 & 0.1 \\ 0.0 & 0.5 & 0.0 \\ 0.0 & 0.0 & 0.1 \\ 0.0 & 0.5 & 0.0 \\ 0.6 & 0.0 & 0.3 \\ 0.0 & 1.5 & 0.0 \\ 0.0 & 0.5 & 0.0 \\ 0.2 & 0.0 & 0.4 \\ 0.0 & 0.0 & 3.1 \\ 0.0 & 0.0 & 0.0 \\ 0.0 & 0.0 & 2.2 \\ 0.0 & 1.1 & 0.0 \\ & & \end{array}$

0.0
1.9
0.2
0.0
0.0
2.2
0.0
0.0
5.4
0.0
0.2
0.0
0.5
0.0
0.9
0.0
1.3
0.0
0.1
0.1
0.0
0.0
0.9
0.0
1.4

$\begin{array}{ll}0.0 & 0.0 \\ 0.0 & 0.3 \\ 0.0 & 0.7 \\ 0.0 & 0.0 \\ 0.1 & 0.0 \\ 0.0 & 1.1 \\ 0.0 & 0.0 \\ 0.0 & 0.0 \\ 0.0 & 0.1 \\ 0.1 & 0.0 \\ 0.0 & 0.0 \\ 0.0 & 0.0 \\ 0.0 & 1.5 \\ 1.0 & 0.0 \\ 0.0 & 0.0 \\ 0.0 & 0.0 \\ 0.0 & 0.2 \\ 0.6 & 0.0 \\ 0.0 & 0.4 \\ 0.0 & 0.0 \\ 0.0 & 0.0 \\ 4.7 & 0.0 \\ 0.0 & 0.9 \\ 0.0 & 0.0 \\ 0.0 & 0.1\end{array}$


Tabie 3.3 Description of Signjficant Fixed-Base Structure Modes

\begin{tabular}{|c|c|c|}
\hline Mode & Frequency (Hz) & Mode Description \\
\hline 10 & 9.49 & $\begin{array}{l}\text { E-W Lateral - Aux . and Fuel } \\
\text { Handling Bldgs. }\end{array}$ \\
\hline 12 & 10.07 & $\begin{array}{l}\text { Torsion - Aux. and Fuel } \\
\text { Handling Bldgs. }\end{array}$ \\
\hline 14 & 11.55 & Torsion - Fuel Handling Bldg. \\
\hline 15 & 11.63 & Torsion - Fuel Handling Bldg. \\
\hline 16 & 11.80 & Torsion - Fuel Handling Bldg. \\
\hline 20 & 12.83 & $\begin{array}{l}\text { N-S Late: } 11 \text { - Aux. and } \\
\text { Fuel Handling Bldgs. }\end{array}$ \\
\hline 21 & 12.93 & $\begin{array}{c}\text { N-S Rotation - Aux, and } \\
\text { Diesel Gen. Bldgs. }\end{array}$ \\
\hline 26 & 15.71 & Vertical - Aux. Bldg. \\
\hline 30 & 17.58 & Vertical - Aux. Bldg. \\
\hline 33 & 17.87 & E-W Rotation - Aux. Bldg. \\
\hline 37 & 19.16 & $\begin{array}{l}\text { N-S Lateral - Aux., Diesel } \\
\text { Generator and Fuel } \\
\text { Handling Bldgs. }\end{array}$ \\
\hline 45 & 21.74 & Torsion - Aux. Bldg. \\
\hline
\end{tabular}




\subsection{NUMERICAL RESULTS}

4. 1

GENERAL

As discussed in Sec. 1, the objectives of this study can be vjewed in the context of two questions:

- How much conservatism is introduced by ignoring SSI or by apProximating SSI effects by a simplified procedure?

- What effect does placing an identicaj structure on different sites and with tifferent foundation condjitions have on structure response?

To address these questions, a number of physical and aralysis scenarios were considered. Table 4.1 itemizes 19 scenarios which form the basis for the results presented here. Cases 1-15 represent best estimate scenarios provided the analysis scerario matches the physical characteristics of the soil, structure, and foujdation. Cases 1 b-19 represent scenarios iith simplifications in the S:I enalysis procedure. These latter cases ai z denoted half-spaces, however, the procedure is typically applied as an approximation to numerous soil profiles other than a unjform half-space, i.e. assuming equivalent soj] properties. Hence, cases $16-19$ represent a broader class of sites. In cases $16-19$, on $y$ structure damping was applied - no attempt to include radiation damping was made.

The responses which formed our data set were specified in Sec. 2.3 and are summarized here:

- Three camponents of peak asceleration (two horizontal and the vertical) at seven node points and six componests of peak accejeration (three 
translational and three rotational) on tlie foundation -. a total of twenty-seven.

- Axial load, in-plane shear, and overturning moment in eight walls, a total of thirty-five sections, and six foundation responses (three forces and three moments) - a total of 111 responses.

- Resporse spectra (2) damping) at seven nodes (three components) and on the foundation (six components) - - a total of twenty-seven.

The numerical comparisons presented here are in the form of mean ratios of response: and coefficients of variation (Cove) for peak accelerations, peak forces, and in-structure response spectra values. The basic procedure to generate the ratios of response was to analyze the soil-structure system for each earthquake (ten earthquakes composed the data set) and calculate the ratios of response for the scenarios to be compared. A mean ratio would then be computed for each response of interest - - the mear. is over the ten earthquakes. Preliminary evajuations of this data grouping like components, like directions, like locations, etc. ware evaluated vs. more global groups such as al] peak accelerations, al1 peak forces, etc. No discernible difference. in the means and covs were observed between the broader and narrower groupings. Hence, data presented here for peak accelerations and peak forces is for these two broad groups.

Peak accelerations and peak forces are scalar quantities which are amenable to comparison. In-structure response spectra are significantly more difficult to compare and interpret in the context of calibration factors. For example, consider Fig. 4.1 which shows a comparison of in-strurture 
response spectra at node 256 (Fig. 2.6) for surface vs. embedded sundation conditions. The effect is one of slight frequency su- * and reductions in amplitude which may be conducive to an average meduction factor. However, Fig. $4 . ?$ shows fixed-uase results vs. surface and embedded foundation conditions which demonstrate large frequency shifts and reductions in amplitude which are not well described by average ratios. Despite these problems, an attempt to summarize the data in the form of calibration factors was made by separating the frequency range of the spectra into three ranges -- 0 to $6 \mathrm{~Hz}$., 6 to $12 \mathrm{~Hz}$, and 12 to $20 \mathrm{~Hz}$. -- and calculating mean ratios and covs for each range. The utility of these factors is limited as discussed above. A more appropriate procedure is to estimate or calculate median spectra based on a design procedure and a hest estimate calculationel procedure. To aid in quantifying the effects of various soil and foundation conditions and SSI analysis assumptions, selected spectra at node 256 , the top of the shear wall structure, are presented here. Additional data at all node points of interest are presented in Reference 6 . 
Table 4.1 Identification of Physical and Analysis Scenarios

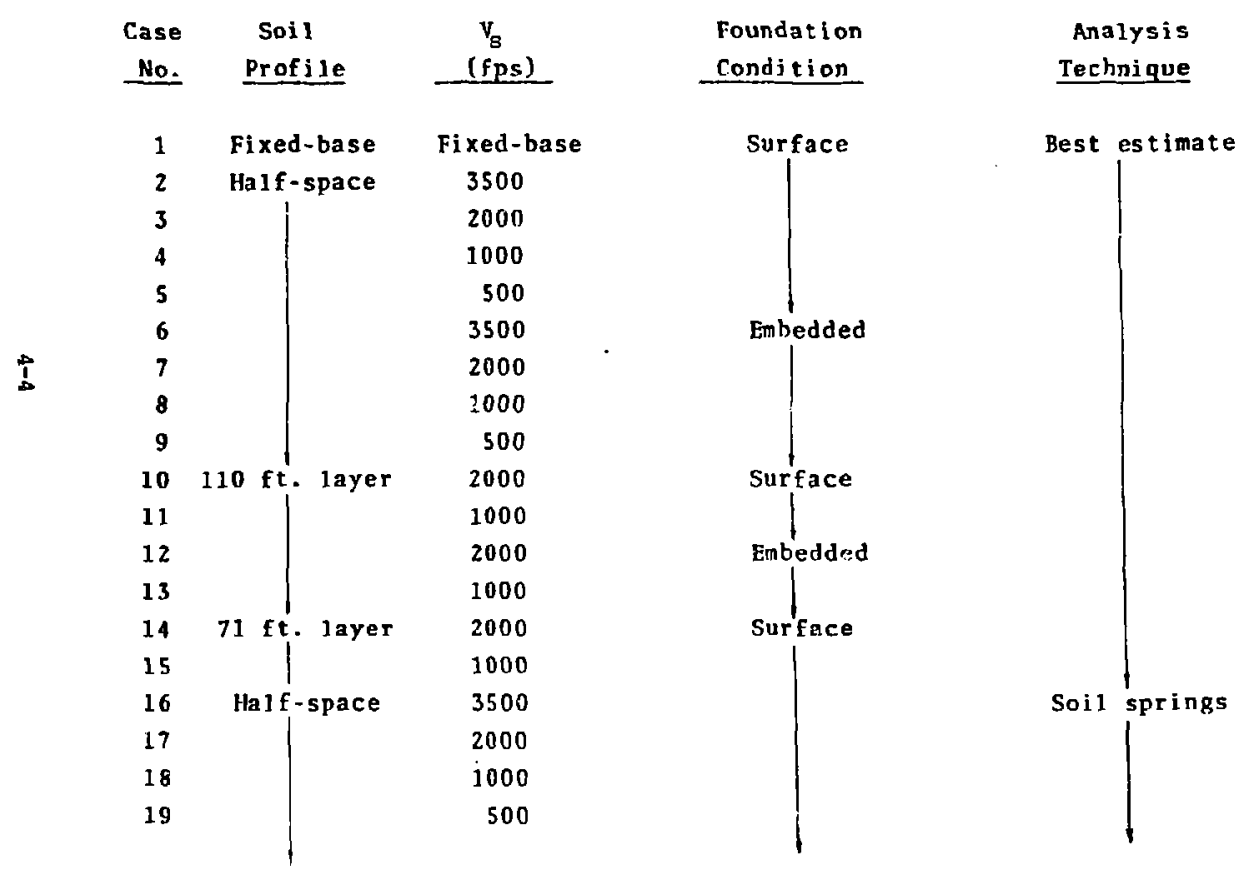


A comparison of in-structure responses for the shear wall structure founded on the soil surface vs. enbedded $39 \mathrm{ft}$. $(\mathrm{e} / \mathrm{r}=0.35)$ pertains to both questions above. First, if one proceeds with a besc estimate analysis procedure for all aspects of SSI but the treatnent of embedment, where the physical structure is embedded to the depth considered here, what is the effect on structure response? Second, in a preliminary design. context, what are the effects on structure response of ambeding the foundation vs. founding it on the surface.

Table 4.2 addresses these questions fot peak accelerations and peak forces. The first set of data is for unifolm half-spaces of varying shear wave velocities. The effect of embedment ranges from 1.17 to 1.31. Here, and for al] other ratios in Table 4.2, the surface-founded structure produced higher response. The second set of data is for a 110 ft. layer of soil overlying a stiff bedrock and for two soil layer stiffnesses. The effect of embedment ranges from 1.3] to 1.38 for this case. The third set of data is a comparison of a su:face-founded structure on a $71 \mathrm{ft}$. soil layer to a structure with an embedded foundation in a $110 \mathrm{ft}$. soil layer. This case corresponds to ignoring embedment in the analysis process anc artificially treating thc structure as being surface - foujdec ai the $71 \mathrm{ft}$. level. For this last case, mean ratios of peak accelerations and peak forces range from 1.57 to 1.75

Table 4.3 contains comparable data for in-structure response spectra. A more informative examination of ir-structure spectra is contained in Fig. 4.1 where the identical comparisons of Table 4.2 are made for node 256 at the top of the structure. The effect of embedment is, in general, to increase the predominant frequency and Ioker the amplitude of response as can be seen from Fig. 4.1 . 
Table 4.2 Mean Ratios of Fcrces and Peak Accejerations for Surface -vs. Embedded Foundation Conditions (Half-Space and Layered Sites)

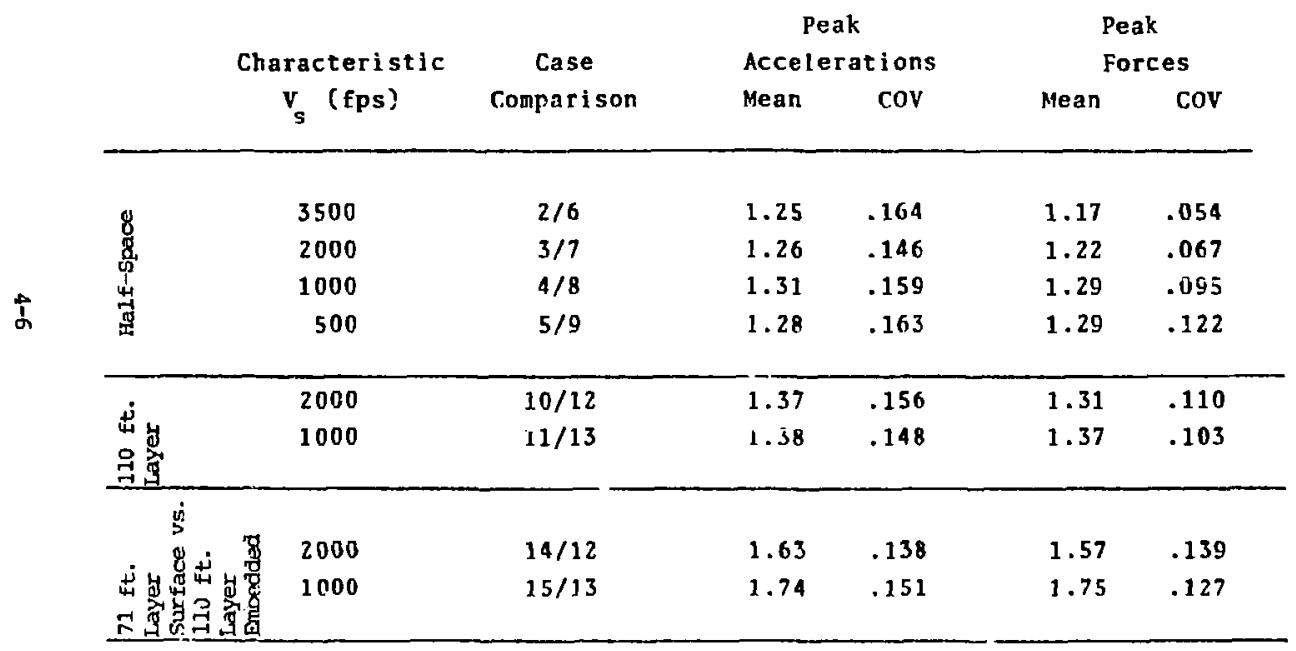




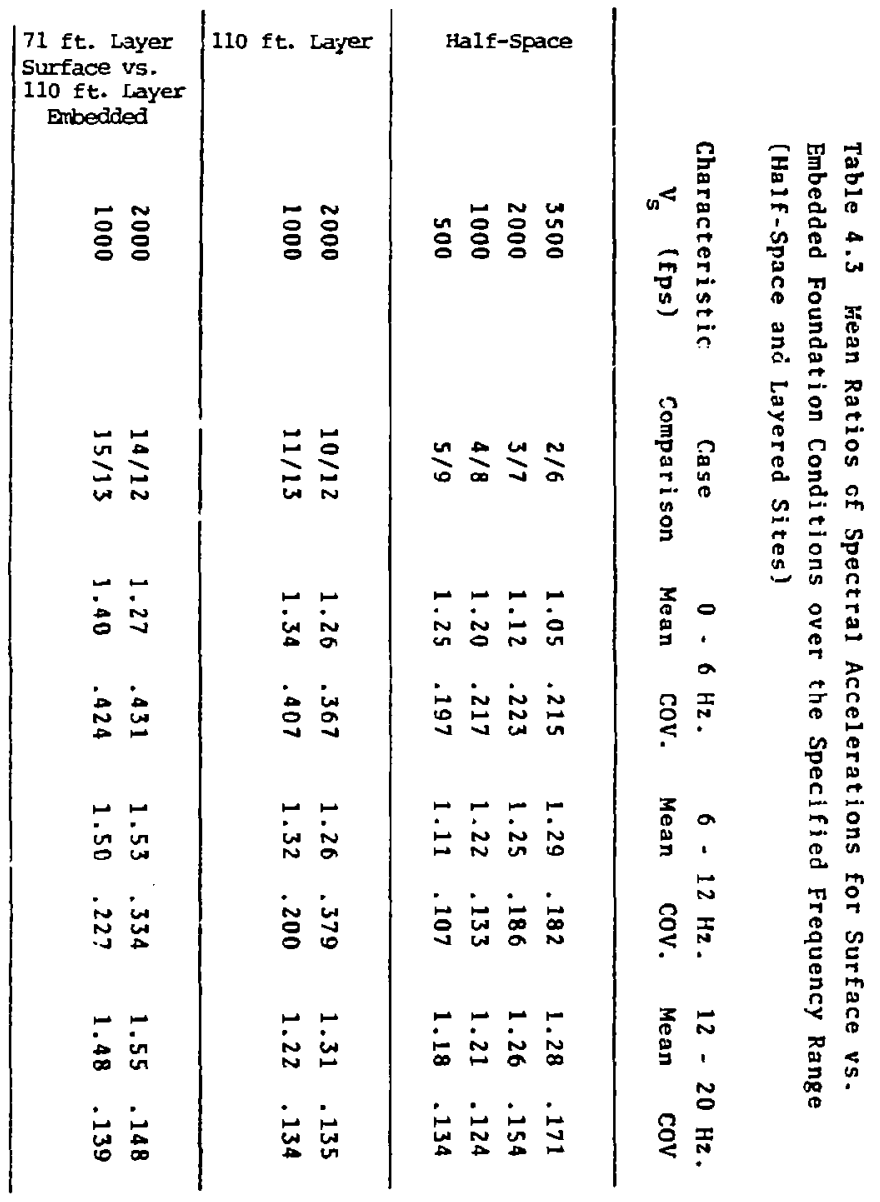


E-W Translation

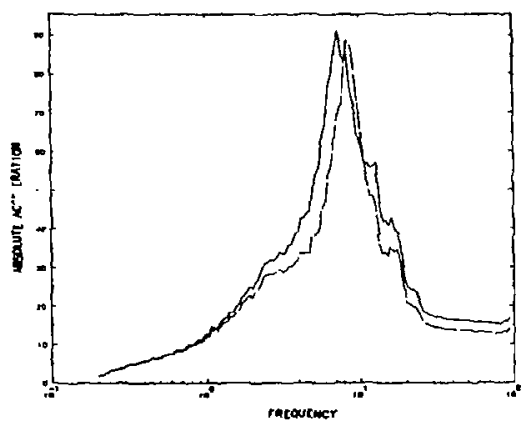

$\stackrel{\infty}{i}$
N-S Translation

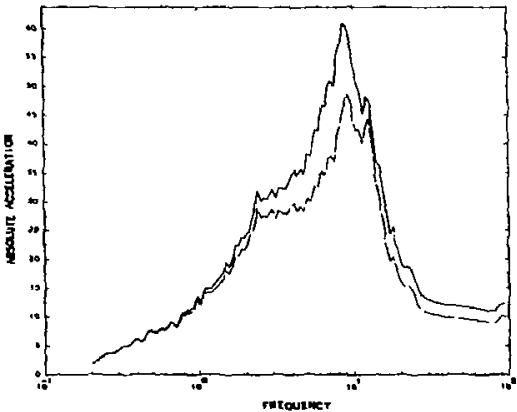

Legend

Surface

Enbedded

Notes

All spectra at 28 damping

Frequencies in $\mathrm{Hz}$

Translations in $\mathrm{ft} / \mathrm{sec}^{2}$

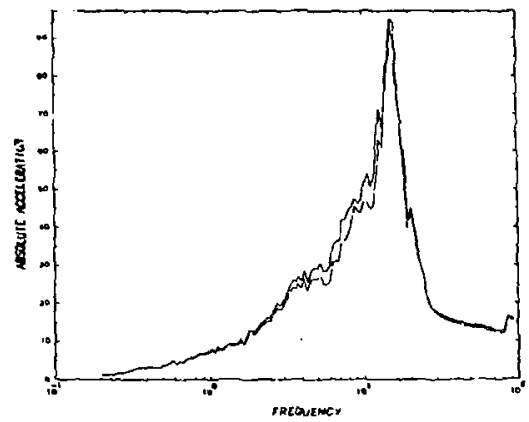

Fig. 4.1 Comparison of In-Structure Response Spectra at Node 256; Surface vs. Embedded Foundation: (a) Uniform Half-space, $v_{s}=3500$ fps, Case 2/Case 6: 
E-W Translation

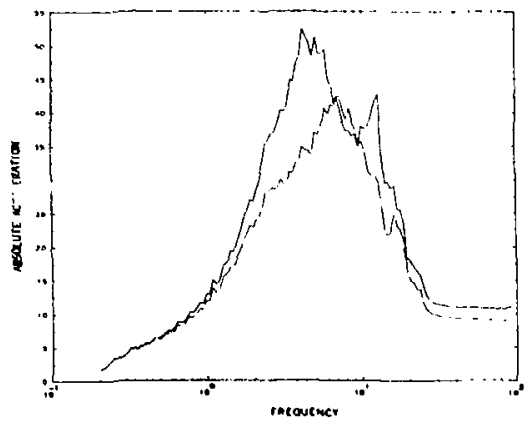

$\stackrel{t}{b}$

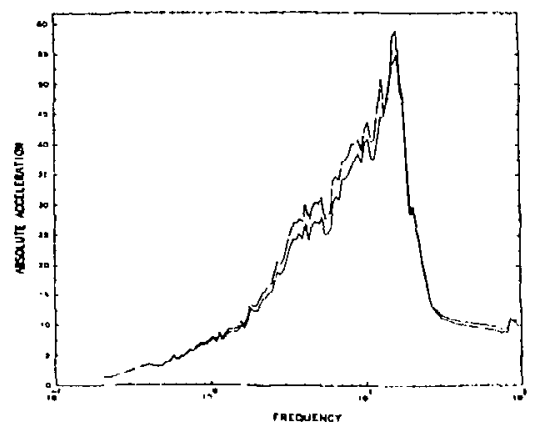

Fig. 4.1(b) Uniform Half-space, $v_{s}=2000 \mathrm{fps}$, Case 3/Case 7;

\section{Lagend}

Surface

Embedded

\section{Notes}

All spectra at 28 damping

Frequencies in $\mathrm{Hz}$

Translations in $\mathrm{ft} / \mathrm{sec}$ 
E-w Translation

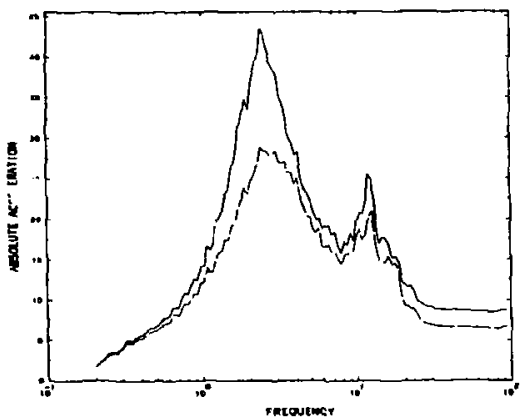

占
N-S Translation

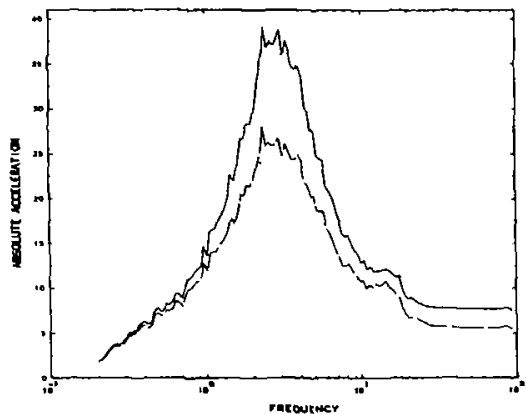

Legend

Surface

Enbedide

Notes

All spectra at 28 damping

Frequencies in $\mathrm{Hz}$

Translations in $\mathrm{ft} / \mathrm{sec}^{2}$

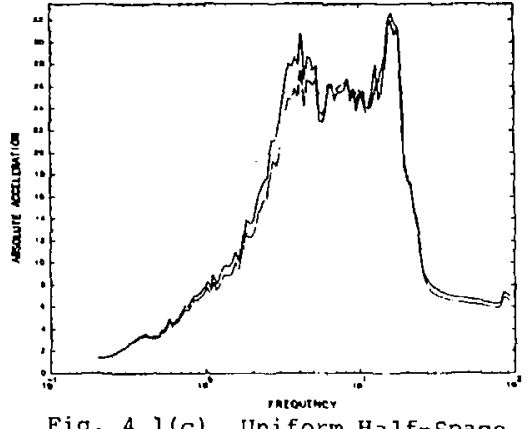

Fig. 4.1(c) Uniform Half-Space, $V_{s}=1000$ [ps, Case 4/Case 8: 
E-W Translation

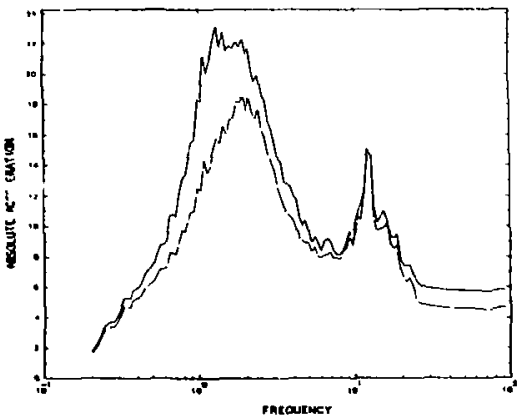

$\stackrel{\leftrightarrow}{1}$

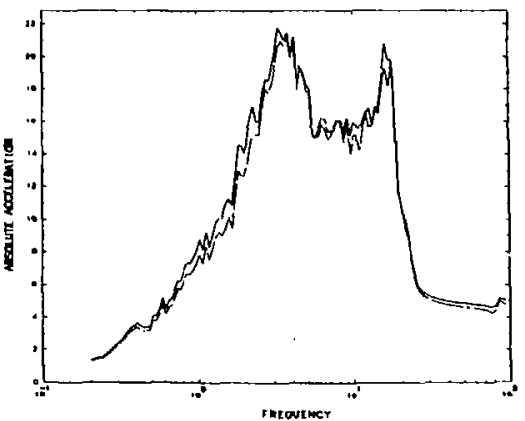

Fig. 4.1(d) Uniform HalE-space, $v_{s}=500$ Eps, Case 5/Case 9;
N-S Translation

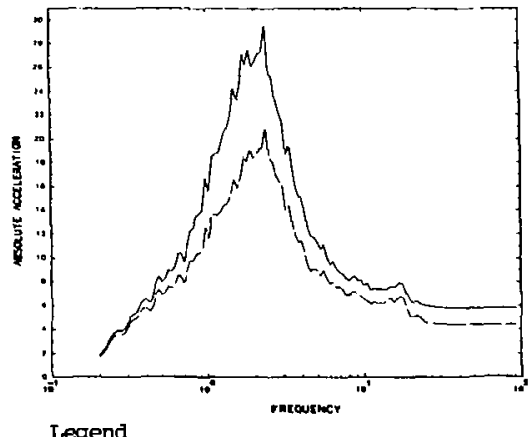

Surface

Embedded

\section{Notes}

All spectra at 28 damping

Frequencies in $\mathrm{Hz}$

Translations in $\mathrm{ft} / \mathrm{sec}^{2}$ 
E-W Translation

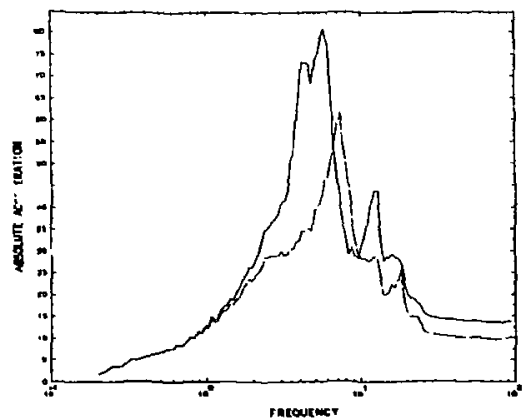

$\stackrel{\vec{n}}{\mathrm{~N}}$
N-S Translation

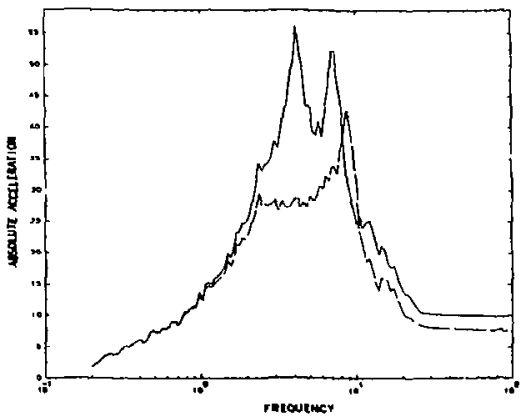

\section{Legend}

Surface

Embedded

\section{Notes}

All spectra at 28 carping

Frequencies in $\mathrm{Hz}$.

Translations in $\mathrm{ft} / \mathrm{sec}^{2}$

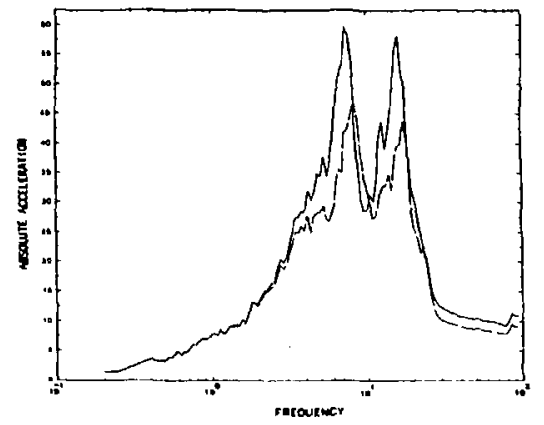

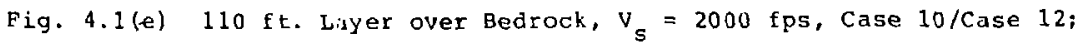


E-W Translation

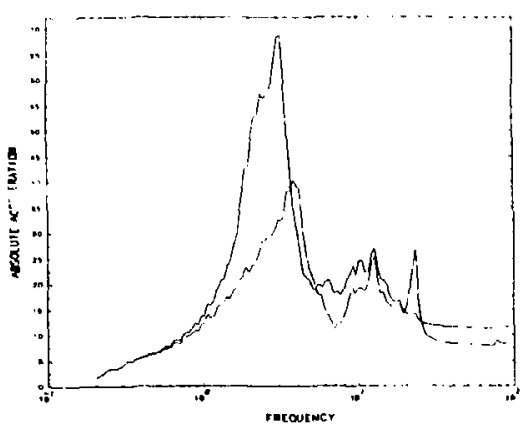

$\stackrel{1}{1}$

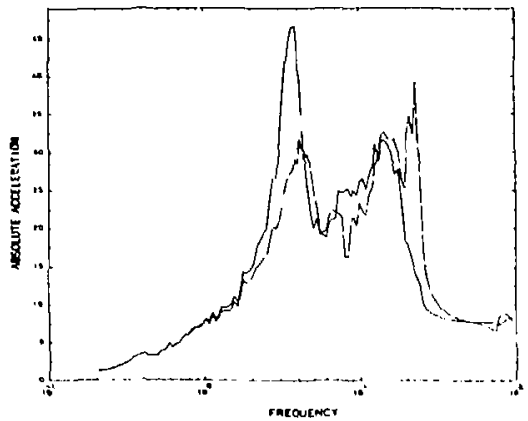

N-S Mranslation

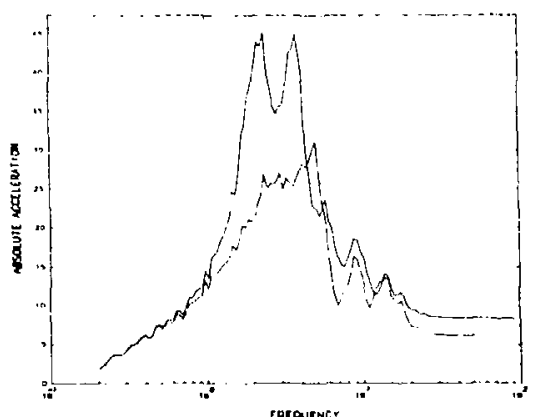

Legend

Surface

Enberded

Notes

Al1 spectra at 2 z darmping

Frequencies in $\mathrm{Hz}$

Translations in $\mathrm{ft} / \mathrm{sec}^{2}$

Fig. 4.1(f) $110 \mathrm{ft}$. Wyycr ovor Bedrock, $v_{s}$ : $1000 \mathrm{fps}$, case 11/Case 13; 
E-W Translation

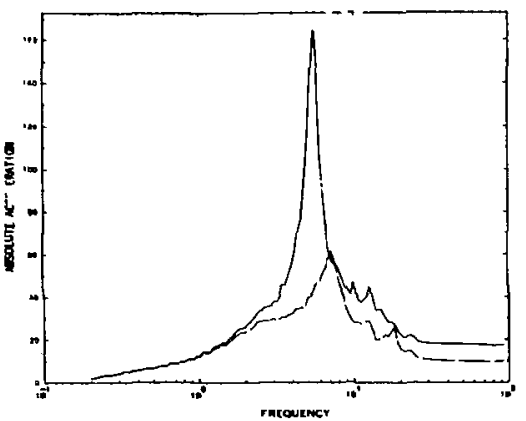

$\stackrel{+}{1}$

\section{Vertical Translation}

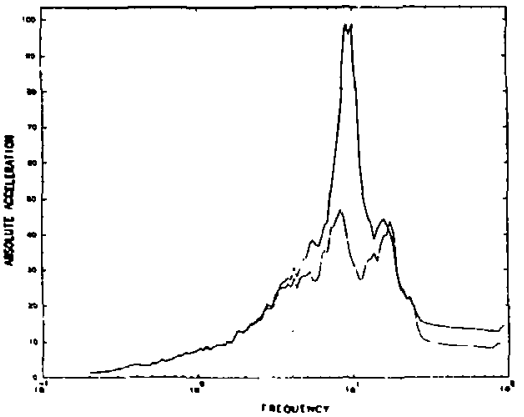

N-S Translation

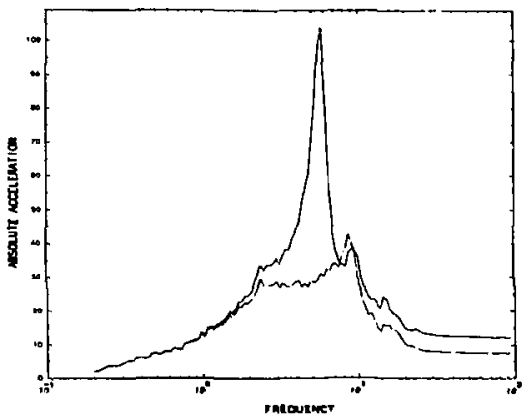

Legend

Surface

Embedded

Notes

All spectra at azz darming

Frequencies in $\mathrm{Hz}$.

Translation in $\mathrm{ft} / \mathrm{sec}^{2}$

Fi7. 4.I (g) $71 \mathrm{ft}$. Layer Surfacr vs. Ilu Ft. Layer Embedded, $V_{s}=2000 \mathrm{fps}$, Case 14/Case 12; 


\section{E-W Translation}

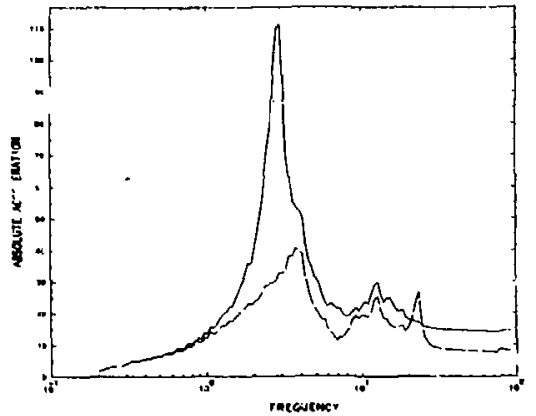

$\underset{⿱ ⺌}{\vdots}$

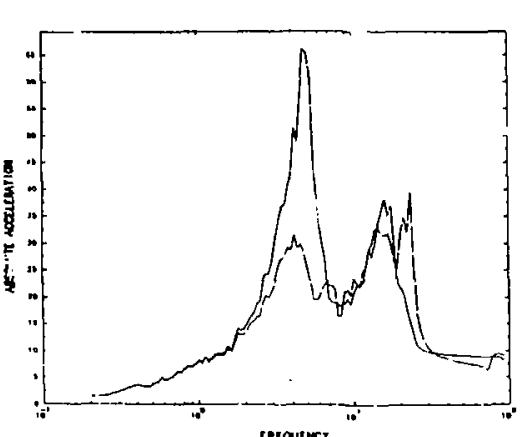

N-S Th unslation

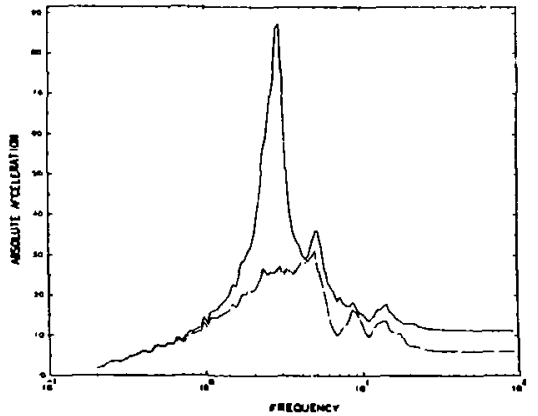

Legend

\section{Surface}

Enbedded

\section{Notes}

A]1 spectra at 28 danping

Frequencies in $\mathrm{Hz}$.

Translations in $\mathrm{ft} / \mathrm{sec}^{2}$

Fig. 4.1(h) $71 \mathrm{ft}$. Layer Surface vs. $110 \mathrm{ft}$. Layer ímbedded, $v_{s}=1000$ fps. 
For many older nuclear power plants, no SSI analysis was performed; a fixed-base analysis yielded accelerations and forcas for design. In general, this simplification introduces significant conservatism in the calculated values of peak accelerations and forces. Table 4.4 quanisites this conservatism for cases 2-15. The first set of dat in Table 4.4 is for surface-founded structures on a uniform half-space of varying stiffness characteristics. Mean ratios vary from 1.07 to 2.14. One site of interest is the uniform half-space of $v_{s}=$ 3500 fps which is typically considered to be a rock site and in many design codes, a fixed-base analysis is permitted to be performed. Note, even in this case, accounting for the supporting medja reduces design laads by a mean of $0.81=$ $(1 / 1,23)$. Peak accelerations are reduced less. The second data set presents comparable data for the structure with an embedded foundation on a uniform half-space of varying stiffness. Mean ratios range from 1.27 to 2.73 . The third data set compares fixed-hase response to that of a structure founded on the surface of a $110 \mathrm{ft}$. soil layer over bedrock. Two soil layer stiffnesses were considered. Mean ratios range from 1.07 to 1.39. The fourth data set compares fixed-base response to that of a structure embedded $39 \mathrm{ft}$. in the $110 \mathrm{ft}$. layer of soj]. Tho soil layer stiffnesses were considered. Mean ratios range from 1.39 to 1.90 . Note, this case for a shear wave velucity of 1000 fps corresponds to the ratios of response likely to exist for the zion AFT complex since the design analysis assumed a fixed-base condition. The final set of data compares the fixed-base case with the surface-founded structure on a $71 \mathrm{ft}$. soil layer. In this case, the mean ratios are near one or slightly greater and slightly less. These cases where the fixed-base rasults are less than the $71 \mathrm{ft}$. layer responses, the soil Jayer and structure are in resonance jeading to higher 
response at some locations especjally at lover elevations. Yide scatter in ajl the ratios is observed.

Table 4.5 contains comparable data for in-structure response spectra. Again, however, these ratios can he misleading. A more informative approach is to exarine in-structure spectra themselves for the cases of interest. Fjgure 4.2 displays response spectra comparisons for node $25 \mathrm{C}$ at the top of the structure. The general trend is a frequency shift to lower values and a reduction in amplitude. 


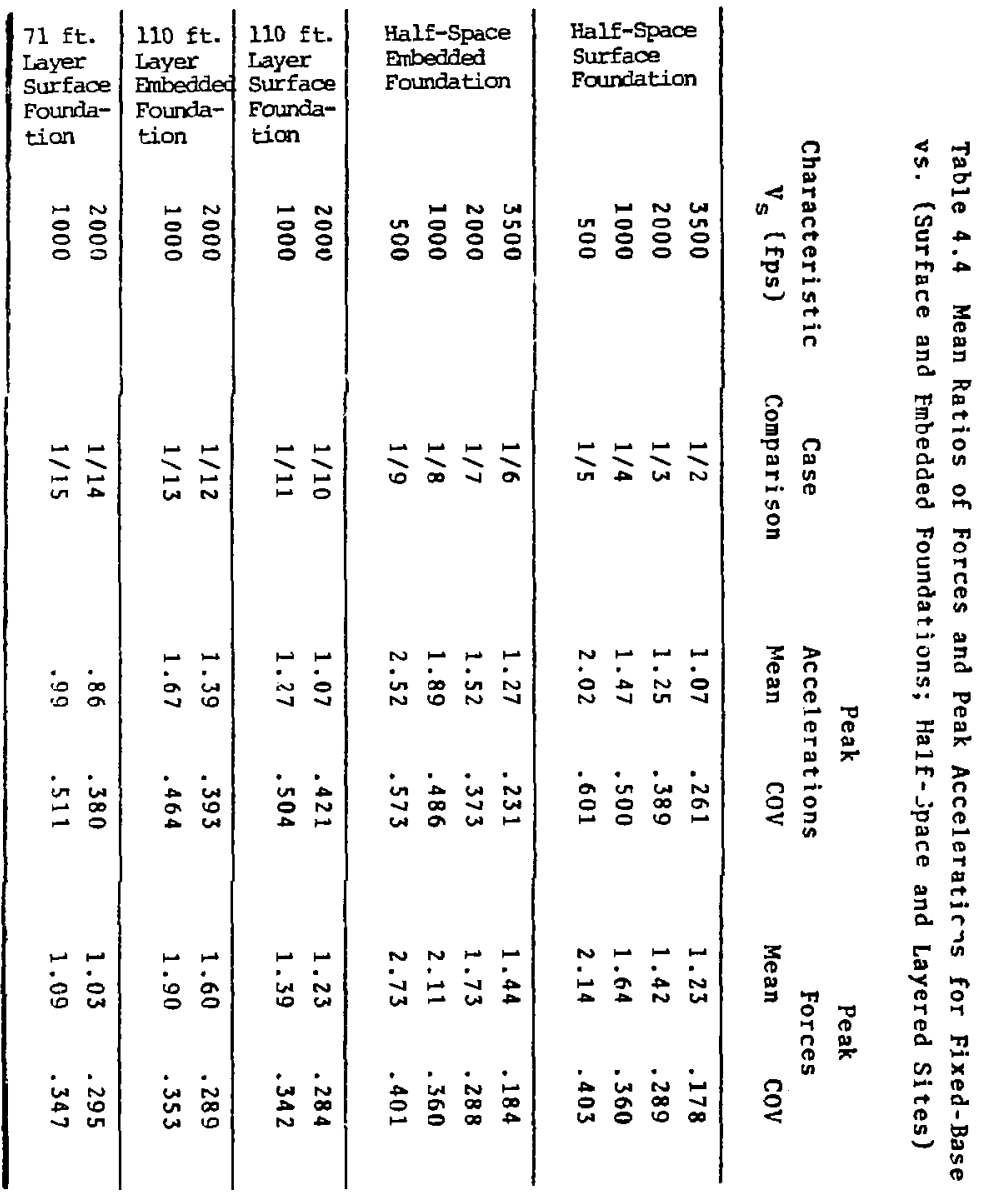


Table 4.5 Mean Ratios of Spectral Accelerations for Fixed-Base vs. (Surface and Embedded Foundations; Half-Space and Layered Sitos) over the Specified Frequency Range

\begin{tabular}{|c|c|c|c|c|c|c|c|c|}
\hline & $\begin{array}{c}\text { Characteristic } \\
V_{s} \text { (frs) }\end{array}$ & $\begin{array}{c}\text { Case } \\
\text { Comparison }\end{array}$ & $\begin{array}{c}0-6 \\
\text { Mean }\end{array}$ & $\begin{array}{l}\mathrm{Hz} \\
\mathrm{COV}\end{array}$ & $\begin{array}{l}6-12 \\
\text { Mean }\end{array}$ & $\begin{array}{l}\mathrm{H} 2 \\
\mathrm{COV}\end{array}$ & $\begin{array}{l}12= \\
\text { Mean }\end{array}$ & $\begin{array}{c}20 \mathrm{~Hz} \text {. } \\
\text { Cov }\end{array}$ \\
\hline \multirow{4}{*}{ 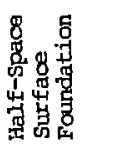 } & 3500 & $1 / 2$ & .97 & .056 & 1.08 & .456 & 1.35 & .292 \\
\hline & 2000 & $1 / 3$ & .94 & .091 & 1.55 & .624 & 1.87 & .404 \\
\hline & 1000 & $1 / 4$ & .94 & .188 & 2.70 & .738 & 2.77 & .532 \\
\hline & 500 & $1 / 5$ & 1.12 & .510 & 4.67 & .790 & 4.10 & .598 \\
\hline \multirow{4}{*}{ 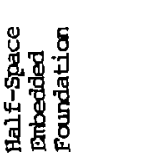 } & 3500 & $1 / 6$ & 1.03 & .025 & 1.30 & .349 & 1.64 & .264 \\
\hline & 2000 & $1 / 7$ & 1.04 & .053 & 1.83 & .571 & 2.29 & .407 \\
\hline & 1000 & $1 / 8$ & 1.11 & .206 & 3.31 & .710 & 3.32 & .523 \\
\hline & 500 & $1 / 9$ & 1.37 & .52 .3 & 5.29 & .759 & 4.78 & .596 \\
\hline \multirow{2}{*}{ 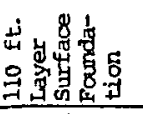 } & 2000 & $1 / 10$ & .92 & .142 & 1.55 & .747 & I. 77 & .445 \\
\hline & 1000 & $1 / 11$ & .92 & .271 & 2.50 & .643 & 2.57 & .578 \\
\hline \multirow{2}{*}{ 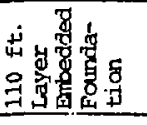 } & 2000 & $1 / 12$ & 1.01 & .038 & 1.69 & .675 & 2.29 & .483 \\
\hline & 1000 & $1 / 13$ & 1.05 & .204 & 3.30 & .642 & 2.96 & .501 \\
\hline \multirow{2}{*}{ 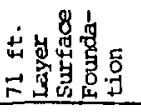 } & 2000 & $1 / 14$ & .91 & .172 & 1.22 & .713 & 1.56 & .544 \\
\hline & 1000 & $1 / 15$ & .88 & .262 & 2.30 & .704 & 2.07 & .553 \\
\hline
\end{tabular}




\section{E-w Translation}

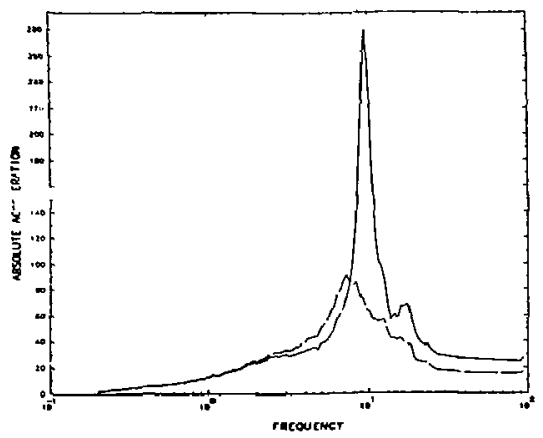

$\stackrel{r}{i}$
N-S Translation

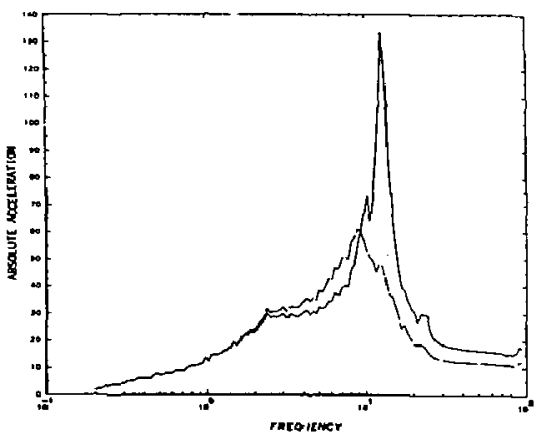

Legend

Fixed-Base Surface

\section{Notes}

All spectra at 28 darping Frequencies in $\mathrm{Hz}$.

Translations in $\mathrm{ft} / \mathrm{sec}^{2}$

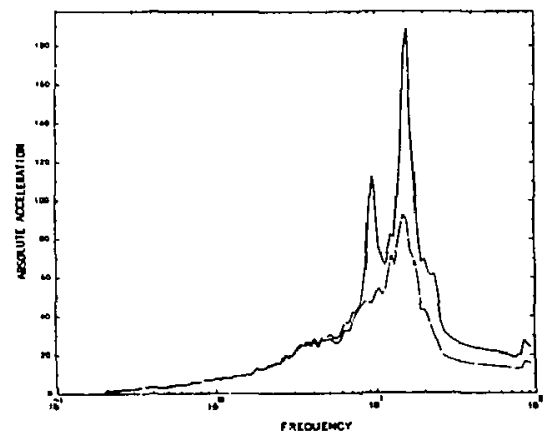

Fig. 4.2 Comparison of In-Structure Response Spectra at Node 256: (a) Fixed-base vs. Uniform Half-space, Surface Foundation, $v_{s}=3500$ Eps, Case 1/Case $2 ;$ 
E-W Translation

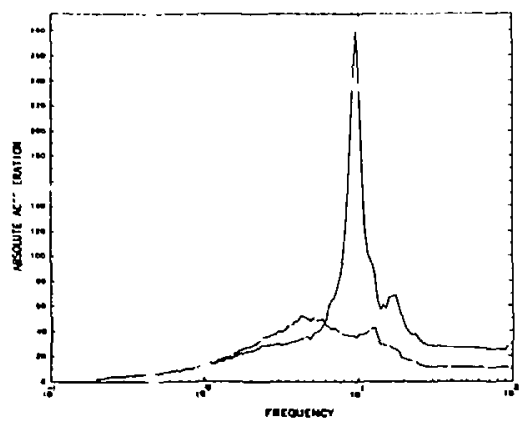

Vertical Translation

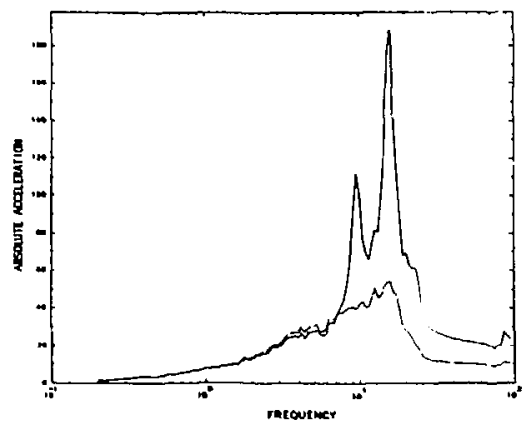

N-S Translation

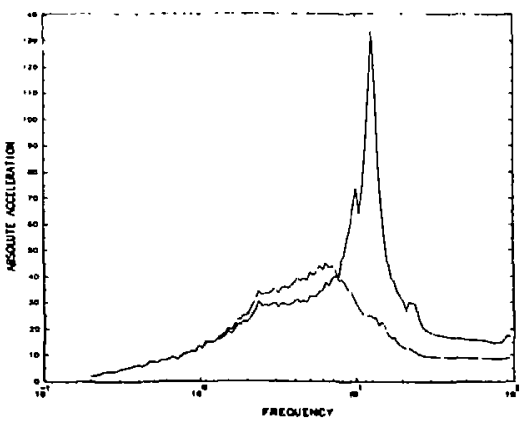

\section{Legend}

Fixed-Base

Surface

Notes

All spectra at 28 samping

Prequencies in $\mathrm{Hz}$.

Translations in $\mathrm{ft} / \mathrm{sec}^{2}$

Fig. 4.2(b) Fixed-base vs. Uniform Half-space, surface Foundation, $v_{5}=2000$ fps. Case 1/Case 3; 
E-W Translation

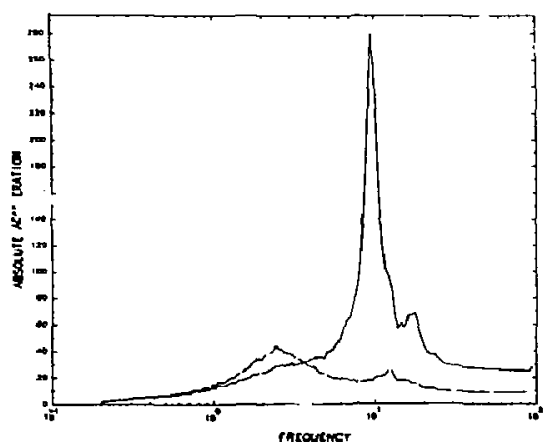

Vertical Translation

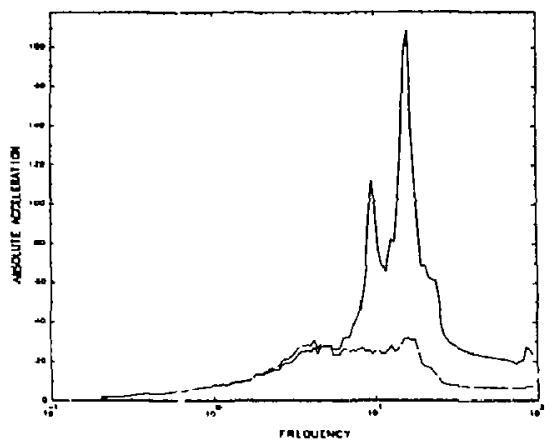

N-S Translation

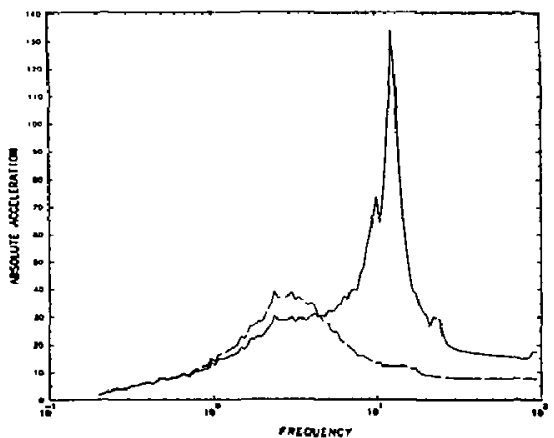

Legend

Fixed-Base

Surface

\section{Notes}

A]l spectra at 28 damping

Frequencies in $\mathrm{Hz}$.

Translations in $\mathrm{ft} / \mathrm{sec}^{2}$

Fig. 4.2(c) Fixed-base vs. Uniform Half-space, Surface Foundation, $v_{s}=1000$ fps. Case 1/Case 4; 
E-W Translation

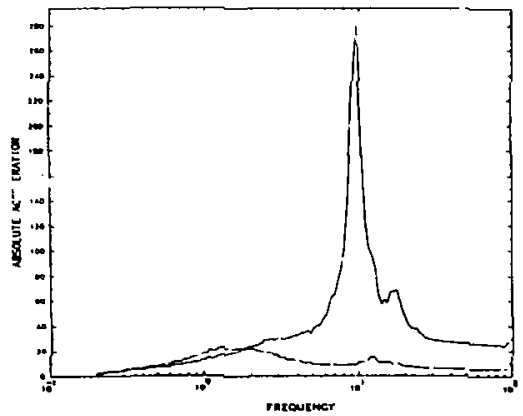

$\stackrel{+}{1}$
Vertical Translation

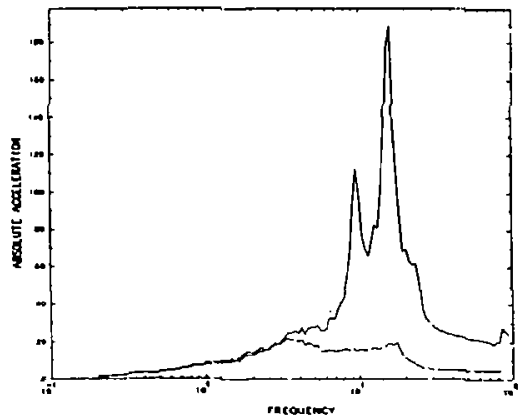

N-S Translation

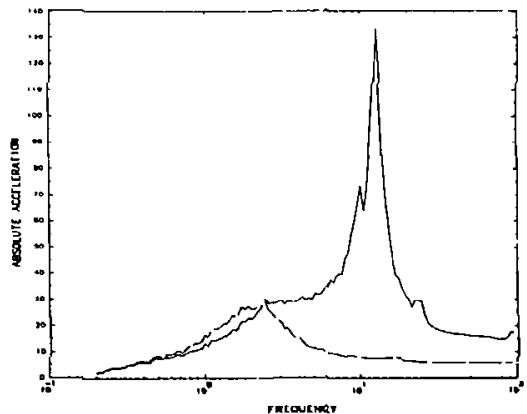

Legenà

Fixed-Base

Surface

Notes

All spectra at 28 damping

Frequencies in $\mathrm{Hz}$.

Translations in $\mathrm{ft} / \mathrm{sec}^{2}$

Fig. 4.2(d) Fixed-base vs. Uniform Half-space, Surface Foundation, $v_{5}=500$ fps, Case I/Case 5; 
E-W Iranslation

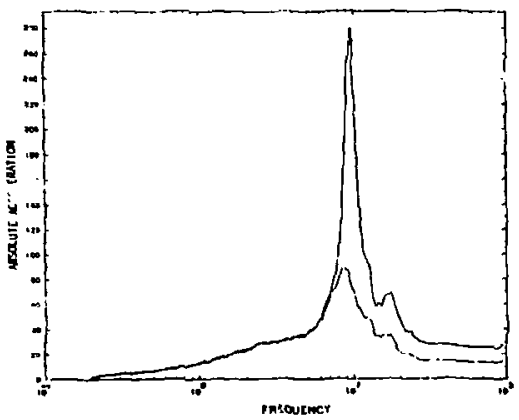

$\vec{i}$

Vertica: Translation

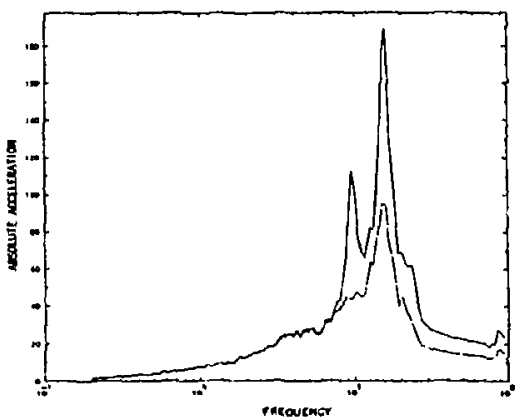

N-S Translation

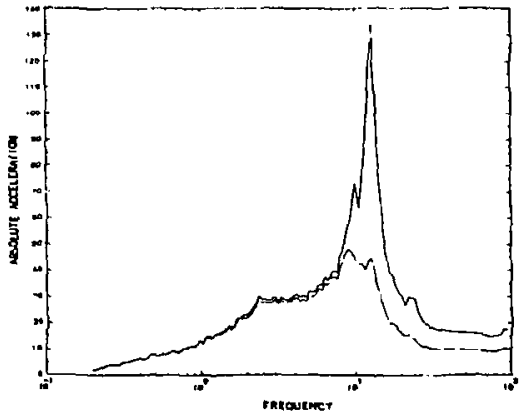

Legend

Fixea-Base

Embedded

Hotes

All spectra at 28 damping

Frequencies in $\mathrm{Hz}$.

Translations in $\mathrm{ft} / \mathrm{sec}^{2}$

Fig. 4.2(e) Fixed-base vs. Uniform Half-space, Embedded Foundation, $s_{s}=3500$ fps, Case 1/Case 6; 
E-W Translation

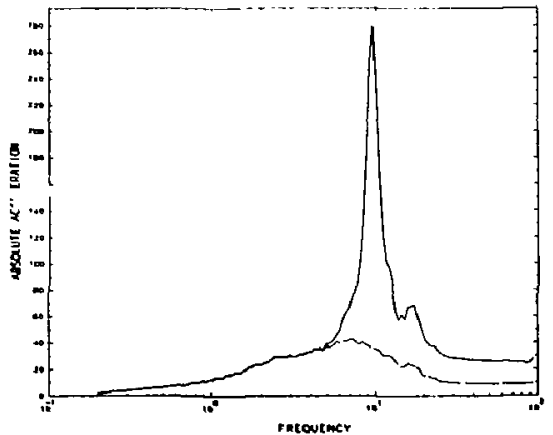

i
Vertical Translation

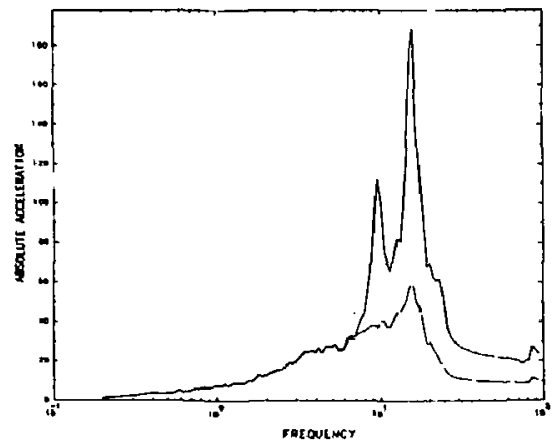

N-S Translation

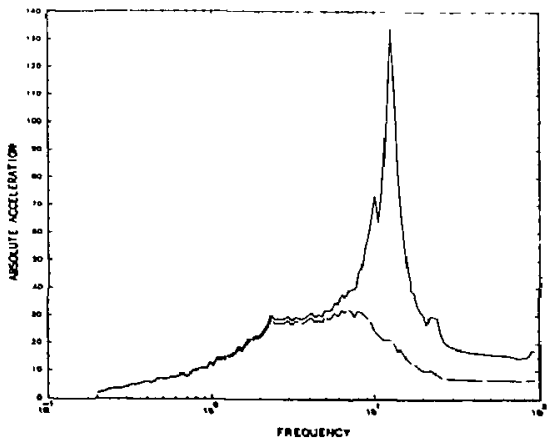

\section{Legend}

\section{Fixed-Base}

Enhedded

INones

All spectra at 28 damping

Frequencies in $\mathrm{Hz}$.

Translations in $\mathrm{ft} / \mathrm{sec}^{2}$

Fig. 4.2(f) Fixed-base vs. Uniform Half-space, Embedded Foundation, $V_{s}=2000 \mathrm{Eps}$, Case I/Case 7; 
E-W Translation

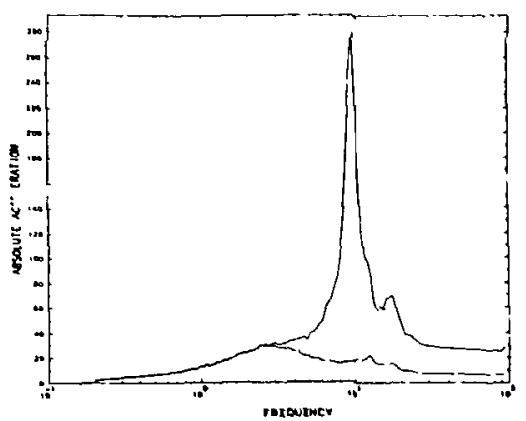

$i_{0}^{\infty}$
Verical Translation

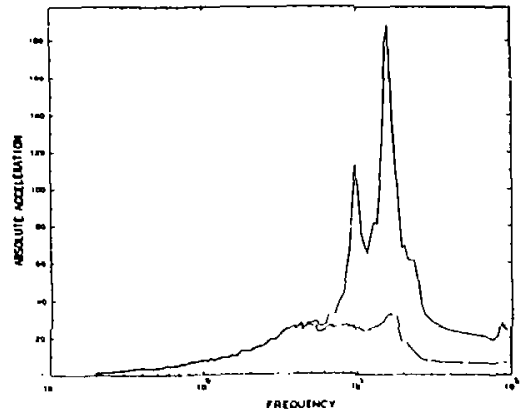

N-S Translation

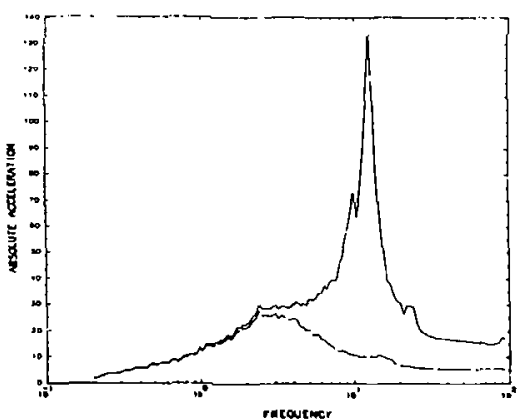

Legend

Fixed-Base

Embeddac

Notes

All spectra at 28 damping

Frequencies in $\mathrm{Hz}$.

Translations in $\mathrm{ft} / \mathrm{sec}^{2}$ 

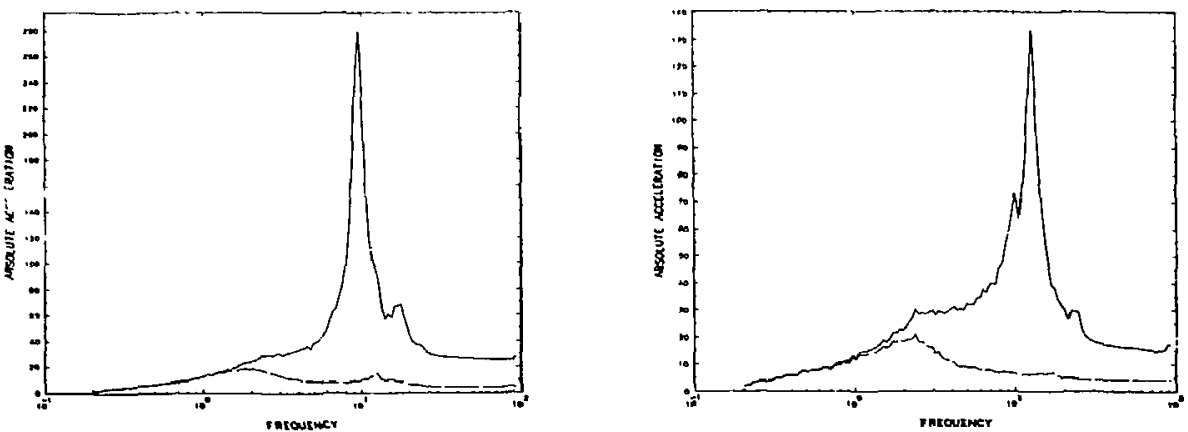

Vertical Translation

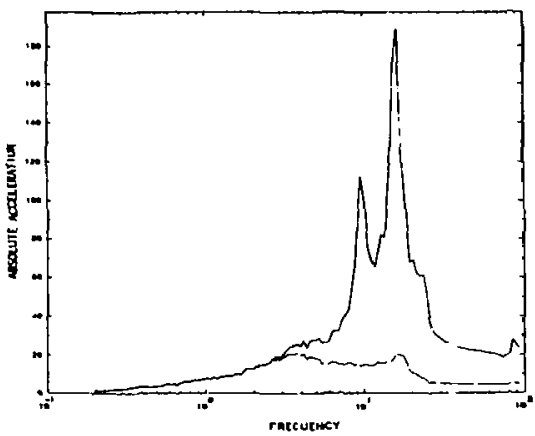

\section{Iegend}

Fixed-Base

Embedded

\section{Notes}

All spectra at 28 damping

Frequencies in $\mathrm{Hz}$.

Translations in $\mathrm{ft} / \mathrm{sec}^{2}$

Fig. 4.2(h) Fixed-base vs. Cniform Half-Space, Embedded Foundation, $v_{s}=500 \mathrm{fps}$, Case 1/Case 9; 
E-W Translation

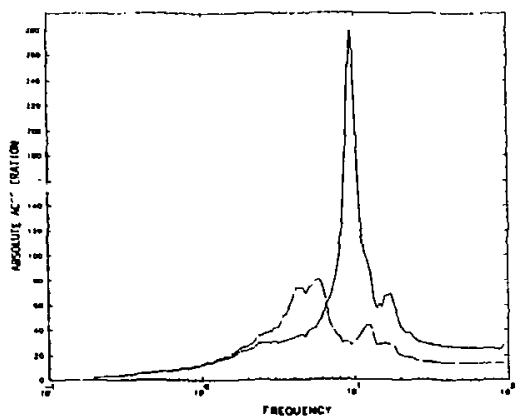

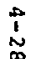

N-S Translation

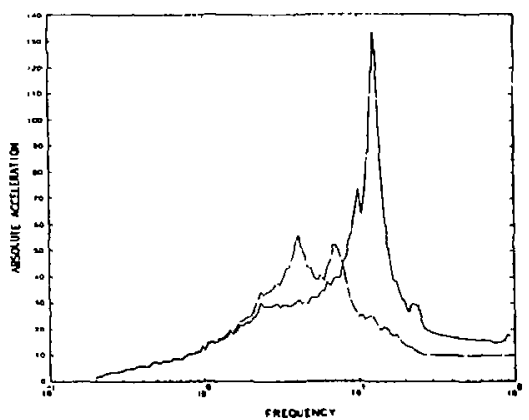

\section{Legena}

Fixed-Base

Surface

\section{Notes}

All spectra at 28 dam

Frequencies in $\mathrm{Hz}$.

Translations in $\mathrm{ft} / \mathrm{sec}^{2}$

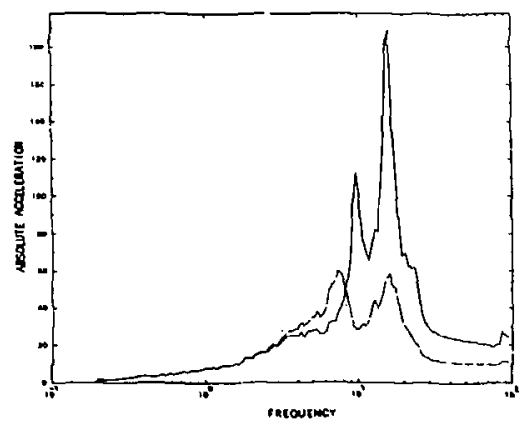

Fig. A.2(i) vixed-base vs. $110 \mathrm{ft}$. Laver over Bedrock, Surfäce Foundation, 
N-W Translation

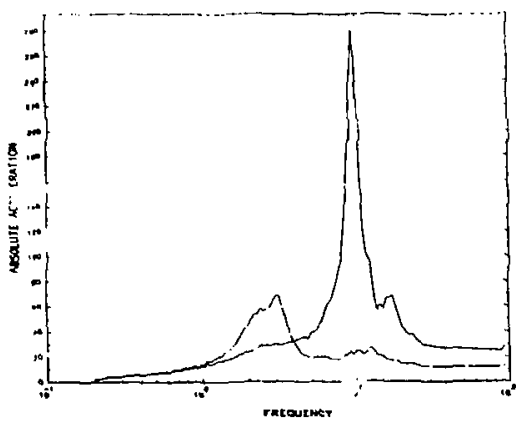

N
N-S 't'rancilation

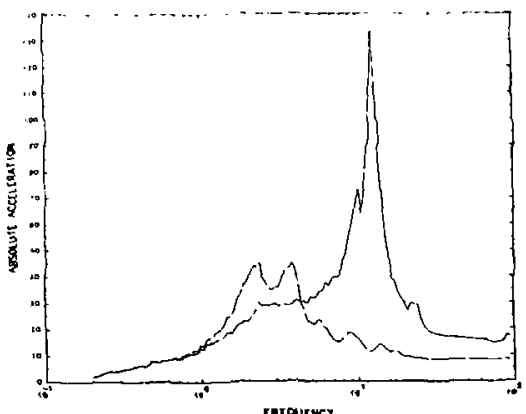

Legend

Fixed-Base _ـ_..._-

Surface

Notes

All spectra at 28 darping

Frequercies in $\mathrm{Hz}$.

Translations in $\mathrm{ft} / \mathrm{sec}^{2}$

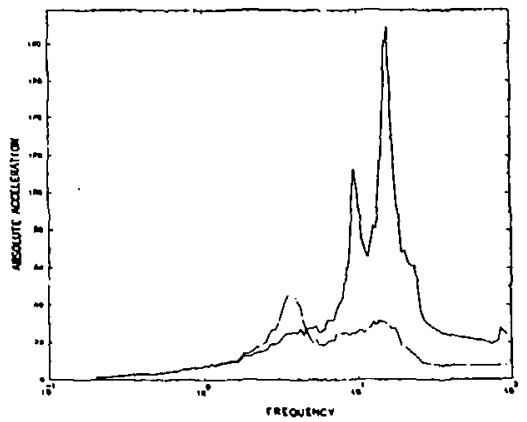

Fig. $4.2(j)$ Fixed-base vs. $110 \mathrm{ft}$. Layer over Bedrcsk, Surface Foundation, $v_{s}=1000 \mathrm{fps}$, Case 1/Case 11; 
E-W Translation

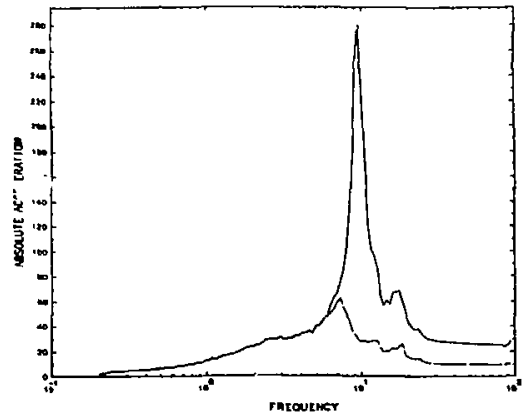

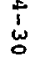

Vertical Translation

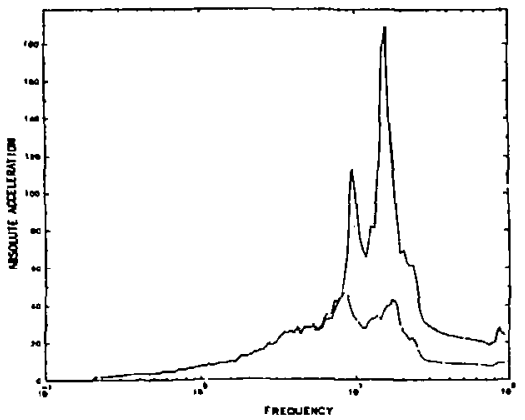

N-5 Translation

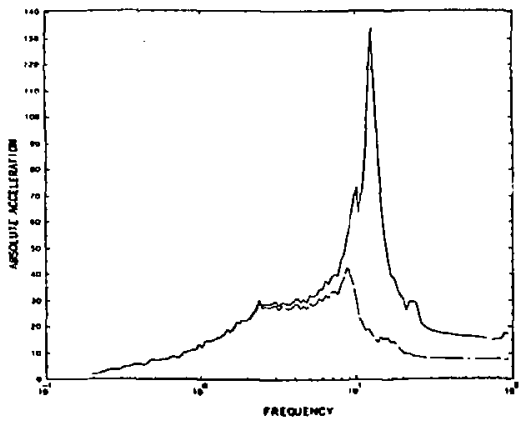

\section{Legend}

Fixed-Base

Enbedded

Notes

AII spectra at 28 damping

Freouencies in $\mathrm{Hz}$.

Traislations in $\mathrm{ft} / \mathrm{sec}^{2}$ 
E-W Translation

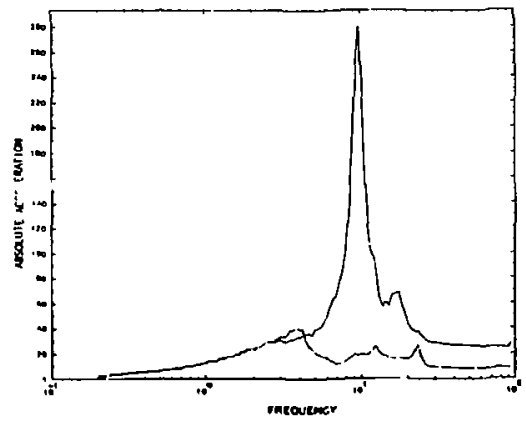

$\stackrel{\overrightarrow{1}}{\omega}$

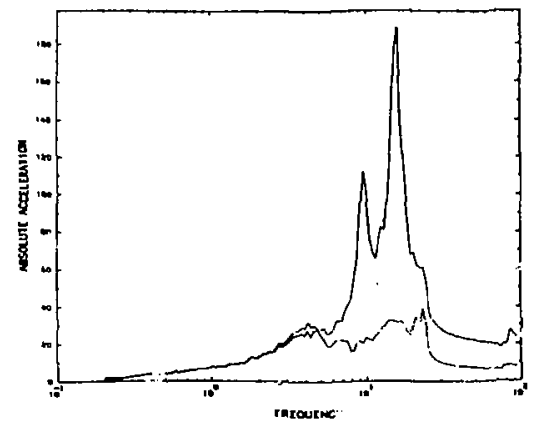

N-S Translation

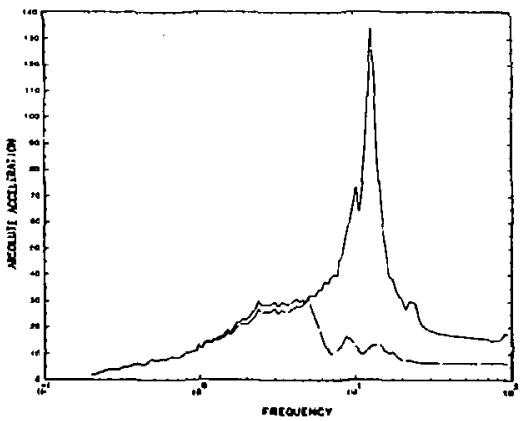

Iegend

Fixed-Base

Embedded

Notes

AlI spectra at 28 damping

Frequencies in $\mathrm{Hz}$.

Translations in $\mathrm{ft} / \mathrm{sec}^{2}$

Fig. 4.2(1) Fixed-base vs. $110 \mathrm{tt}$. Layer over Bedrock, Embedded Foundation, $\mathrm{V}=1000$ fos. Case $1 /$ Case $13:$ 
E-W Translation

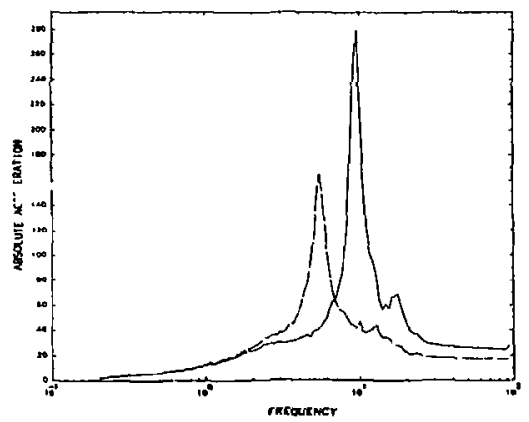

Vertical Translation

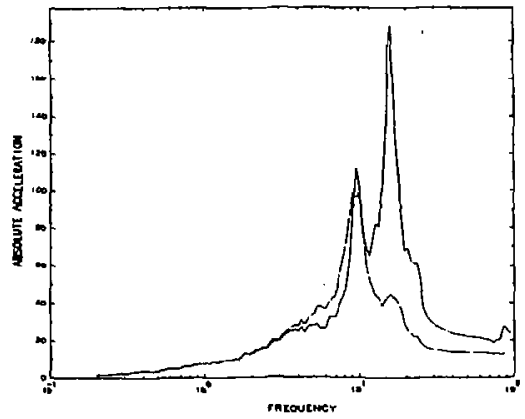

N-S Translation

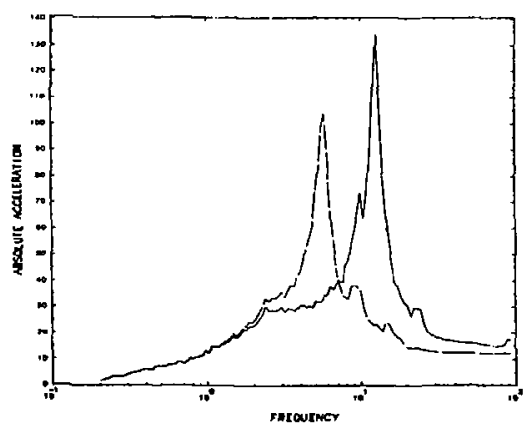

Isgend

Fixed-Base

Surface

Notes

All spectra at 28 damping

Frequencies in $\mathrm{Hz}$.

Translations in $\mathrm{ft} / \mathrm{sec}^{2}$

Fig. 4.2(m) Fixed-base vs. 71 ft. Layer over Bedrock, Surface Foundation, 
E-W Translation

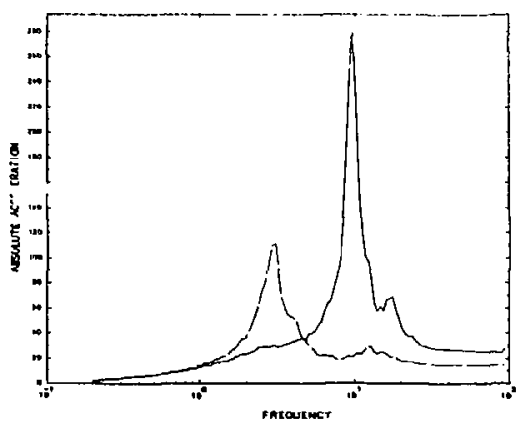

w

\section{Vertical Translation}

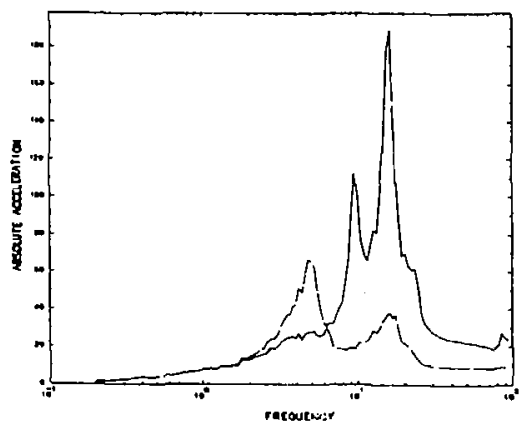

N-S Translation

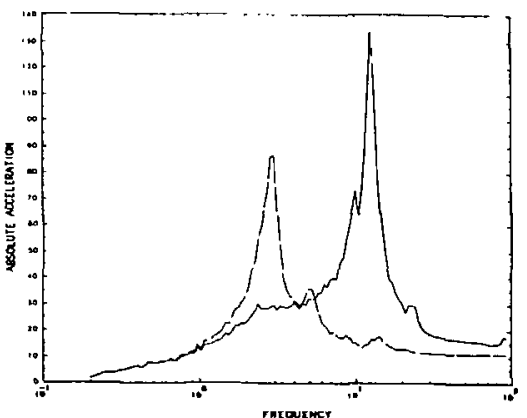

Legend

Fixed-Base

Surface

Jotes

All spectra at 28 darming

Frequercies in $\mathbf{H z}$.

Translations in $\mathrm{ft} / \mathrm{sec}^{2}$

Fig. 4.2(n) Fixed-base vs. $71 \mathrm{ft}$. Layer over Bedzock, Surface Foundation, $V_{\mathbf{s}}=1000 \mathrm{fps}$, Case 1/Case 10 ; 
4.4 SOIL SPRINGS VS. (SURFACF AND EMBEDNEN FOUNDATIONS)

Simplified SSI analyses were performed for the shear wal structurc and for four sets of soil springs as described in Sec. 3.4.3. These simplified analyses assumed only structure damping to act as an energy dissipation mechanism, i.e. ignoring radiation damping. These cases simulate a surface-founder structure whose SSI characteristics are treated in a simplifiec fashion. The first data set of Table 4.5 quantifjes thjs effect. Mean ratios of response vary from 2.53 to 2.44. The secone data set of Tabje 4.6 compares the simplified SSI results with responses calculated assuring the structure to be emhedier $39 \mathrm{ft} .(\mathrm{e} / \mathrm{r}=0.35)$. Mear. ratios of response vary from $1.84 \mathrm{tc}$ 3.12. Uriform haj-spaces were assumed for alj best estinats cases. Significant conservatisms are observed.

Table 4.7 compares comparable data for jn-structure spectra. Agajn, a better evaluation of the effect of this simplified SSI procedure on in-structure spectra can be madc by directly comparing the response spectra. Figure 4.3 compajes response spectra at node 256 as before. Significant reductions are observed. 
Table 4.6 Mean Ratios of Peak Accelerations for Soil Springs vs. (Surface and Embedded Foundations; Half-Space Site)

$\begin{array}{ccc}\text { Characteristic } & \text { rase } & \text { Psak } \\ v_{s} \text { (fps) } & \text { Comparison } & \text { Accelerations } \\ & & \text { Hean } \text { cov }\end{array}$

\begin{tabular}{|c|c|c|c|c|}
\hline \multirow{4}{*}{ 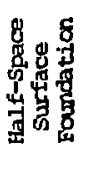 } & 3500 & $16 / 2$ & 1.53 & .290 \\
\hline & 2000 & $17 / 3$ & 1.86 & .354 \\
\hline & 1000 & $18 / 4$ & 2.44 & .432 \\
\hline & 500 & $19 / 5$ & 2.11 & .382 \\
\hline \multirow{4}{*}{ 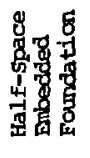 } & 3500 & $16 / 6$ & 1.84 & .244 \\
\hline & 2000 & J/7 & 2.26 & .348 \\
\hline & 1000 & $18 / 8$ & 3.12 & .429 \\
\hline & 500 & $19 / 9$ & 2.65 & .400 \\
\hline
\end{tabular}


Tabje 4.7 Mean Ratios of Spectra] Accelerations for Soij Springs vs. (Surface and Embedded Foundations; Ha]f-Space Site) over the Specified Frequency Range

\begin{tabular}{|c|c|c|c|c|c|c|c|c|}
\hline & & & & & $\mathrm{ral} A \mathrm{C}$ & ccelerat & ns & \\
\hline & $\begin{array}{c}\text { Characteristic } \\
V_{s} \text { (fps) }\end{array}$ & $\begin{array}{c}\text { Case } \\
\text { Comparison }\end{array}$ & $\begin{array}{c}0- \\
\text { Mesn }\end{array}$ & $\begin{array}{c}6 \mathrm{~Hz} . \\
\mathrm{COV}\end{array}$ & $\begin{array}{c}6- \\
\text { Mean }\end{array}$ & $\begin{array}{c}32 \mathrm{~Hz} . \\
\mathrm{COV}\end{array}$ & $\begin{array}{l}12- \\
\text { Mean }\end{array}$ & $\begin{array}{c}20 \mathrm{~Hz} . \\
\mathrm{COV}\end{array}$ \\
\hline & 3500 & $16 / 2$ & 1.02 & .081 & 1.69 & .420 & 1.32 & .308 \\
\hline 员过 & 2000 & $17 / 3$ & 1.20 & .523 & 1.65 & .564 & 1.38 & .308 \\
\hline 出岁票 & 1000 & $18 / 4$ & 1.47 & .712 & 1.67 & .359 & 1.89 & .318 \\
\hline वृष कू & 500 & $19 / 5$ & 1.58 & .693 & 1.81 & .313 & 1.88 & .260 \\
\hline $8_{0} ;$ & 3000 & $16 / 6$ & 1.10 & .154 & 2.09 & .447 & 1.62 & .332 \\
\hline 象要严 & 2000 & $3.7 / 7$ & 1.39 & .077 & 1.96 & .560 & 1.69 & .307 \\
\hline 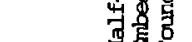 & 1000 & $18 / 8$ & ]. $\varepsilon 0$ & .813 & 2.05 & .392 & 2.29 & .328 \\
\hline 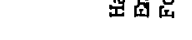 & 500 & $10 / 9$ & 1.09 & .770 & 2.05 & .350 & 2.21 & .283 \\
\hline
\end{tabular}


E-W Translation

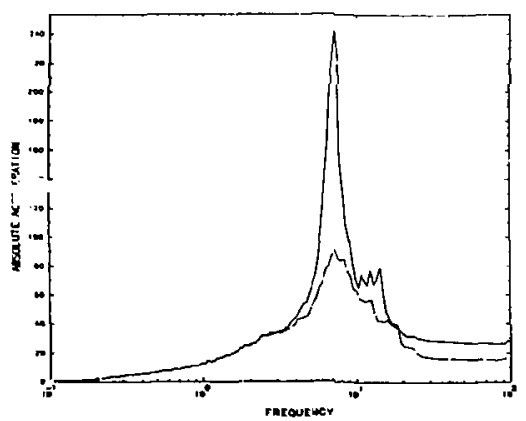

$\stackrel{t}{\omega}$
N-S Translation

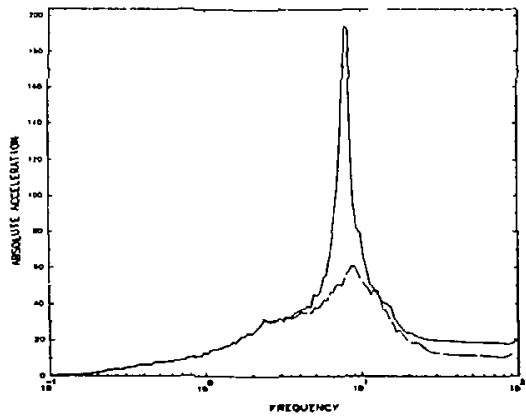

Iegend

Soil Springs

Surface

Notes

All spectra at 28 damping

Frequencies in $\mathrm{Hz}$.

Iranslations in $\mathrm{ft} / \mathrm{sec}^{2}$

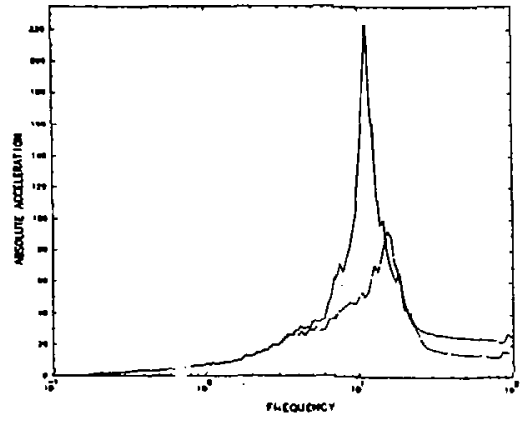

Fig. 4.3 Comparison of In-Structure Response Spectra at Node 256; Soil Springs $v_{5}$. Uniform Half-Space; (a) $v_{s}=3500 \mathrm{Eps,} \mathrm{Surface}$ Foundation, Case 16/C̄ase 2: 
E-W Translation

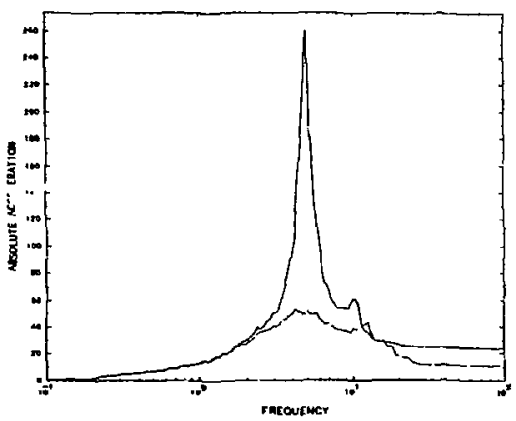

$\vec{i}$
N-S Translation

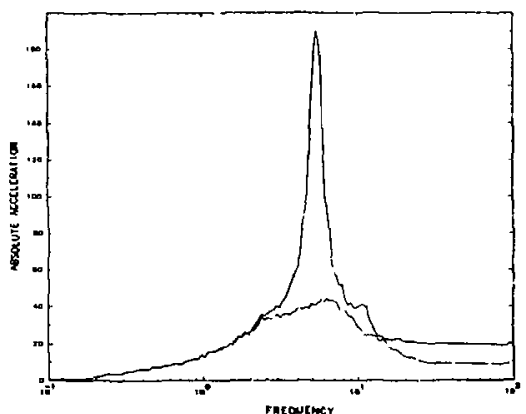

\section{Legend}

Soil Springs

surface

Notes

AlI spectra at 28 damping

Frequencies in $\mathrm{Hz}$.

Translation in $\mathrm{ft} / \mathrm{sec}^{2}$ 
E-W Translation

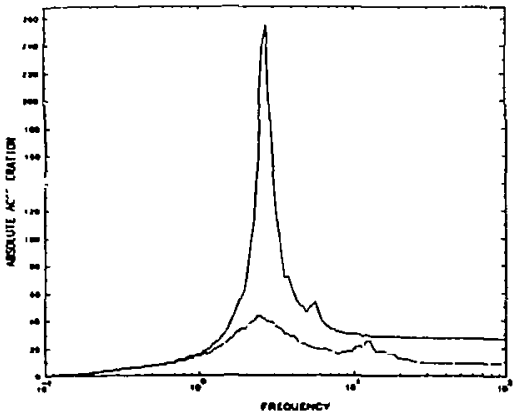

$\vec{t}$
N-S Translation

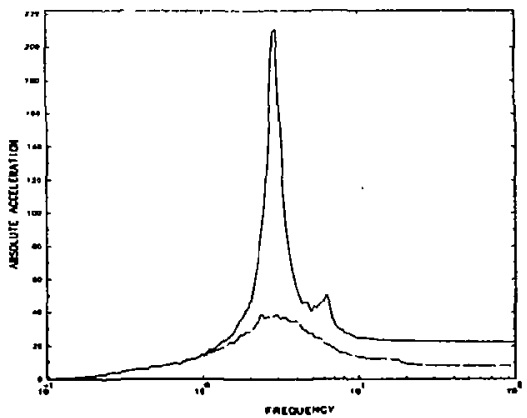

\section{Legend}

Soil Springs

Surface

\section{Notes}

All spectra at 28 damping

Frequencies in $\mathrm{Hz}$.

Translations in $\mathrm{ft} / \mathrm{sec}^{2}$

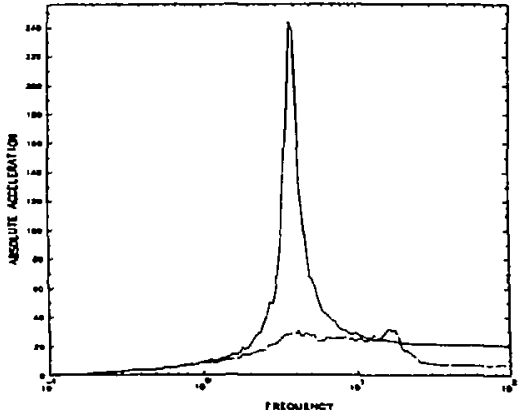

Fig. 4.3(c) $V_{s}=1000$ fps, Surface Foundation, Case $18 /$ Case 4 . 
E-W Translation

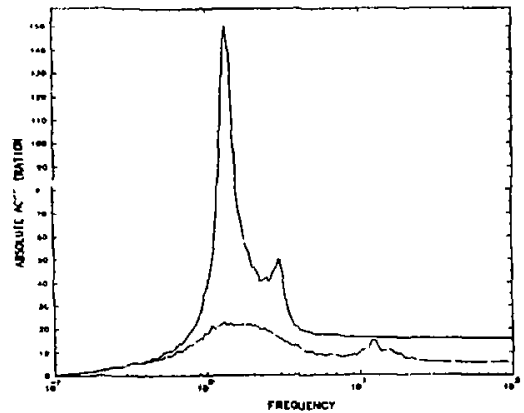

1
0

\section{N-5 Translation}

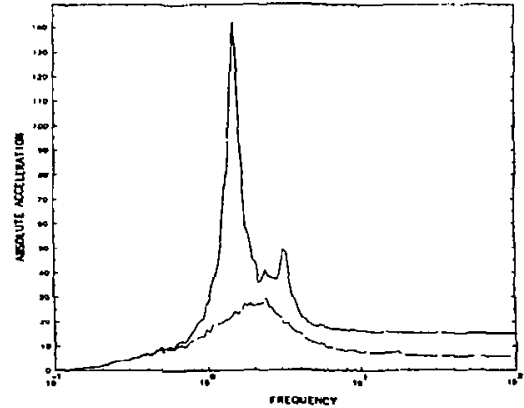

Legend

Soil Springs

Surface

Notes

AIl spectra at 28 camping

Frequencies in $\mathrm{Hz}$.

Translations in $\mathrm{it} / \mathrm{sec}^{2}$

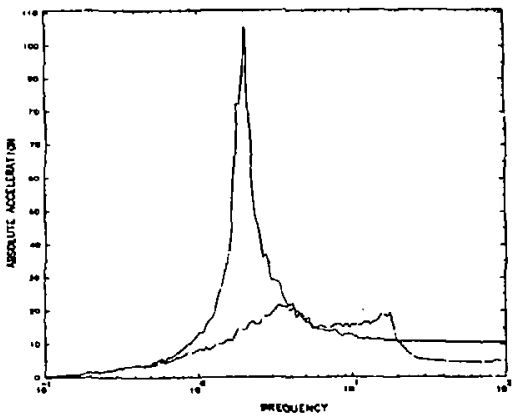

Fig. 4.3(d) $v_{s}=500$ fps, Surface Foundation, Case $19 /$ Case 5. 
E-W Translation

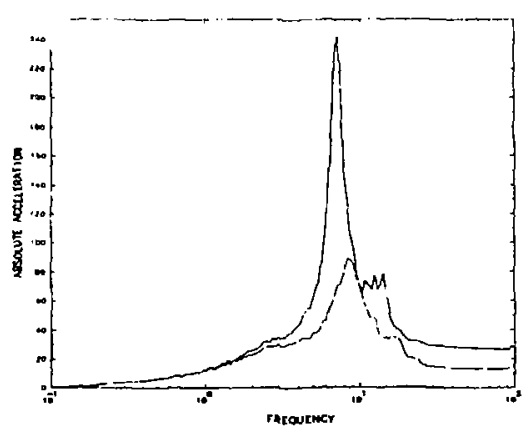

$\stackrel{\Delta}{\Delta}$

\section{Vertical Translation}

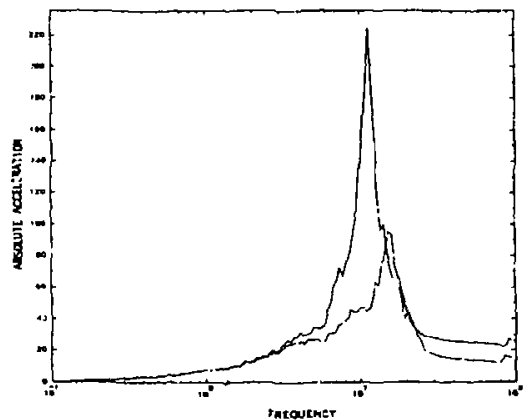

N-S Translation

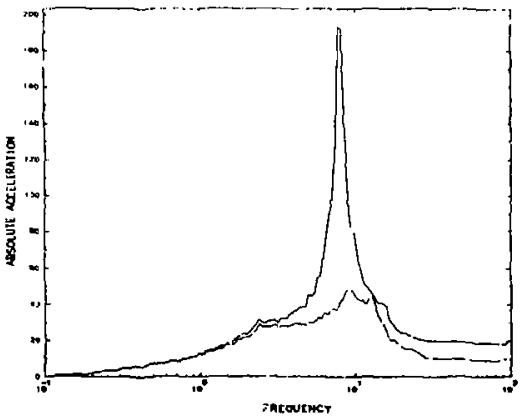

\section{Legend}

Soil Springs

Erbudded

\section{Notes}

All spectra it 28 danping Frecuencies in $\mathrm{kz}$. Irarslations in ftisec ${ }^{2}$

Fig. 4.3(e) $v_{s}=3500$ fps, Embedded Foundation, Case 16/Case 6 . 
E-W Translation

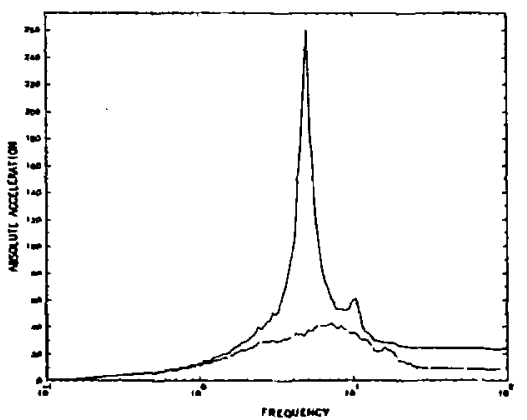

$\stackrel{t}{N}$

\section{Vertical Translation}

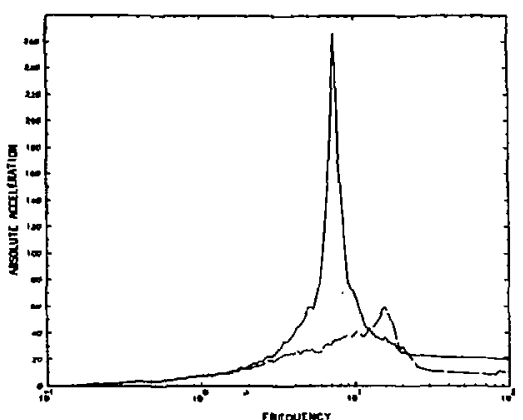

N-S Translation

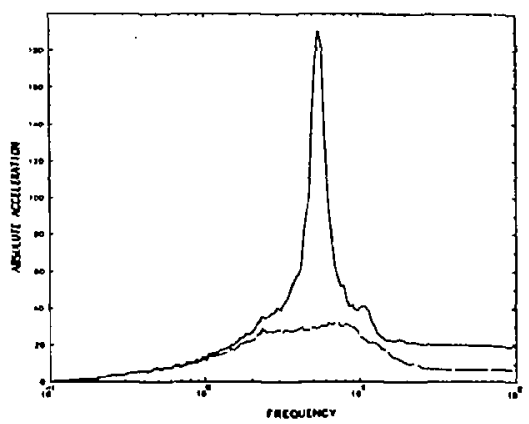

\section{Legend}

Soil Springs

Embedded

\section{Totes}

All spectra at 28 danping

Frequencies in $\mathrm{Hz}$.

Translations in $\mathrm{ft} / \mathrm{sec}^{2}$ 
E-W Translation

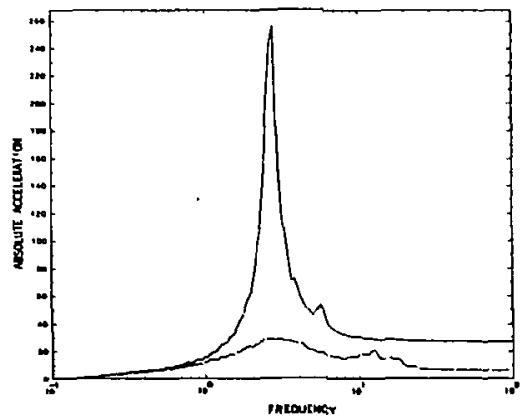

Vertical Translation

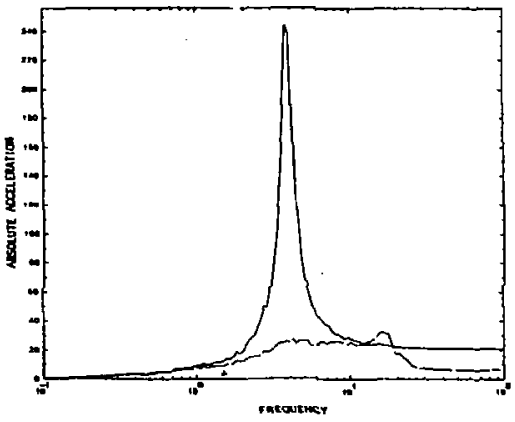

N-S Translation

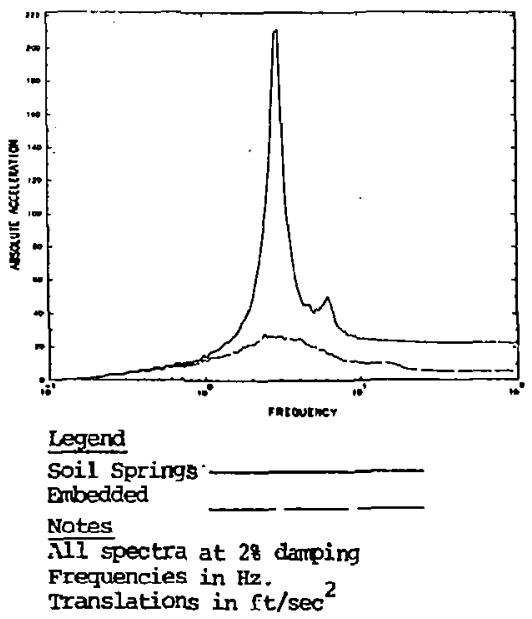

Fig. 4.3(g) $V_{s}=1000 \mathrm{fps}$, Embedded Foundation, Case 18/Case 8; 
E-W Translation

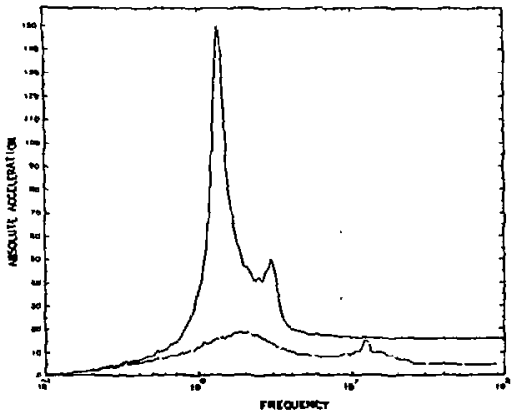

$\vec{t}$
N-S Translation

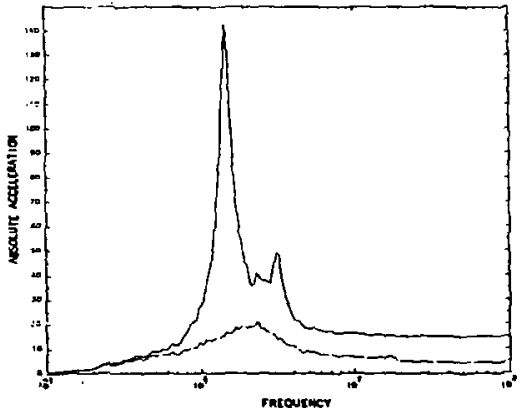

Legend

Soil Springs

moedded

Nutes

AlI spectra at 28 danping

Frequencies in $\mathrm{Hz}$.

Translations in $\mathrm{ft} / \mathrm{sec}^{2}$

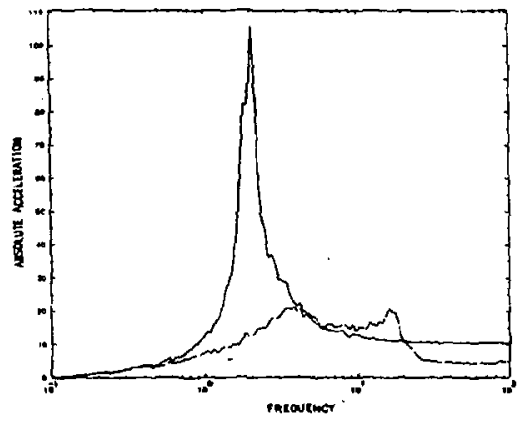

Fig. $4.3(\mathrm{~h}) \quad v_{c}=500$ fps, Lmimud Foundation, Case $19 /$ Case $9 ;$ 


\subsection{EFFECT OF INCREASED STRUCTUFE DAMPING}

The sensitivjty of in-structure peak acceleraticns and peak forces to changes in structure damping is an important consideration. Many design procedures select conservatively biased damping values; also, as excitation levels increase an structure failure is approached, higher damping values ( $10 \%$ of critical or greater) can be expected. Hence, one needs to answet with increasing structure damping for soil and rock fourded structures?

Table 4.8 quantifies the effect of increased structure damping on peak accelerations and peak forces for the typical shear wal structure. Fixed-base and two uniform half-spaces of shear wave velocities of 2000 fps and 1000 fps were considered. Structure damping of $4 \%, 7 \%$, and $10 \%$ of critical were studicd; comparisons between the three were made. The result stows structure damping to be important only foi the fixed-base condition. Whenever SSI is properly modeled and the site can be characterized as soil rather than extremely stiff rock, changes in structure damping have a minimal effect on response. This is due to the fact that one must consider the soi and structurc as a system and the energy dissipation characteristics of the supporting media dominate the system's behavior. Table 4. presents comparable data for in-structure response ipectra. 
Table 4.8 Mean Ratios of Forces and Peak Accelcrations

for Surface Foundation Conditions at 48,78 , and 108

Structure Damping (Half-Space site).

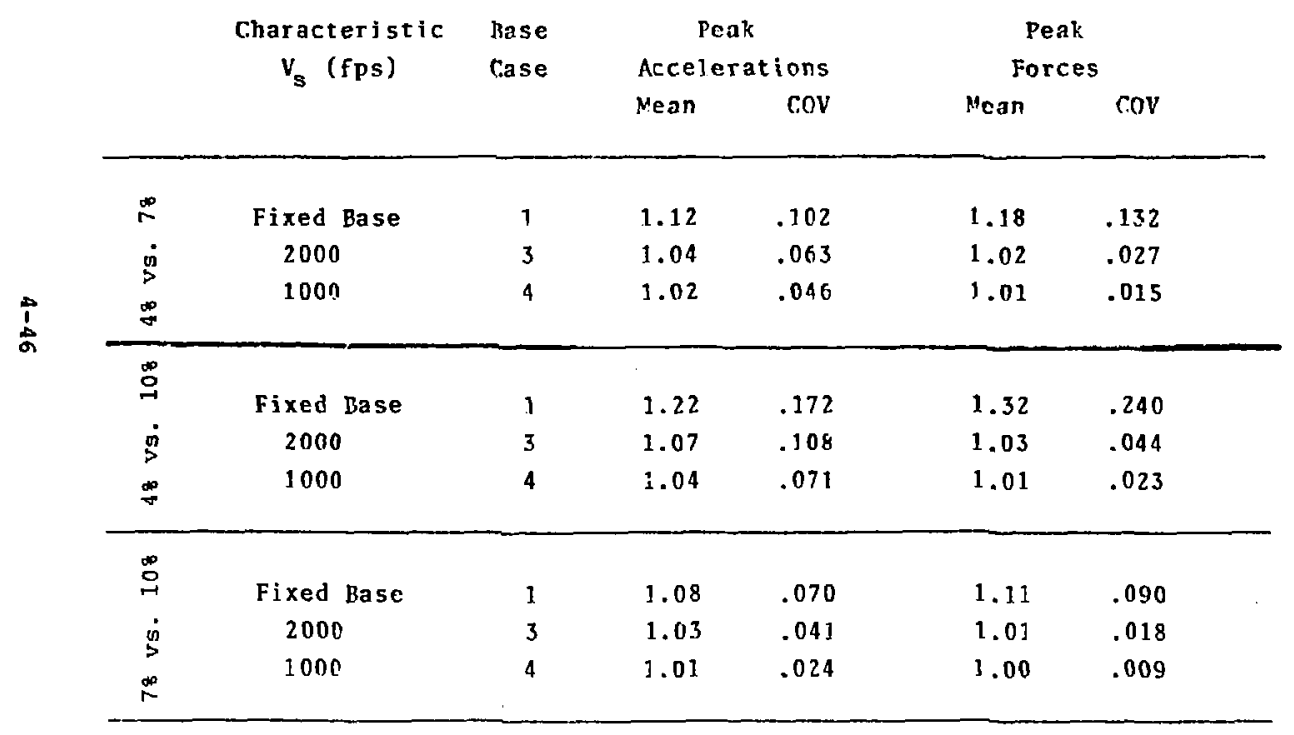


Table 4.9 Afcan Ratios of Spectral Accelerations for Surface Foundation Conditions at 48, 7t, and 108 structure namping over the specified Frequency Range (I'nle-Space Sitc).

\begin{tabular}{|c|c|c|c|c|c|c|c|c|}
\hline & $\begin{array}{c}\text { Characteristic } \\
V_{s}\left(f_{p s}\right)\end{array}$ & $\begin{array}{l}\text { Base } \\
\text { Case }\end{array}$ & $\begin{array}{c}0- \\
\text { Mean }\end{array}$ & $\begin{array}{l}\text { Spectral } \\
6 \mathrm{H:z} \\
\text { Cov }\end{array}$ & $\begin{array}{l}\text { Accel } \\
6-1 \\
\text { Mean }\end{array}$ & $\begin{array}{l}\text { erations } \\
2 \mathrm{~Hz} \text {. } \\
\text { rov }\end{array}$ & $\begin{array}{l}32-2 \\
\operatorname{Mean}\end{array}$ & $\begin{array}{c}20 \mathrm{~Hz} . \\
\mathrm{COV}\end{array}$ \\
\hline $\begin{array}{l}\dot{\infty} \\
\dot{8} \\
\dot{8}\end{array}$ & $\begin{array}{l}2000 \\
1000\end{array}$ & $\begin{array}{l}3 \\
4\end{array}$ & $\begin{array}{l}1.00 \\
1.00\end{array}$ & $\begin{array}{l}.010 \\
.011\end{array}$ & $\begin{array}{l}1.05 \\
1.04\end{array}$ & $\begin{array}{l}.089 \\
.081\end{array}$ & $\begin{array}{l}1.09 \\
1.08\end{array}$ & $\begin{array}{l}.096 \\
.091\end{array}$ \\
\hline 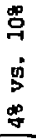 & $\begin{array}{l}2000 \\
1000\end{array}$ & $\begin{array}{l}3 \\
4\end{array}$ & $\begin{array}{l}1.00 \\
1.00\end{array}$ & $\begin{array}{r}.017 \\
.019\end{array}$ & $\begin{array}{l}1.09 \\
1.06\end{array}$ & $\begin{array}{l}.164 \\
.147\end{array}$ & $\begin{array}{l}1.17 \\
1.13\end{array}$ & $\begin{array}{l}.169 \\
.158\end{array}$ \\
\hline 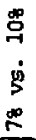 & $\begin{array}{l}2000 \\
1000\end{array}$ & $\begin{array}{l}3 \\
4\end{array}$ & $\begin{array}{l}1.00 \\
1.00\end{array}$ & $\begin{array}{l}.007 \\
.007\end{array}$ & $\begin{array}{l}1.04 \\
1.02\end{array}$ & $\begin{array}{l}.062 \\
.053\end{array}$ & $\begin{array}{l}1.06 \\
1.05\end{array}$ & $\begin{array}{l}.068 \\
.060\end{array}$ \\
\hline
\end{tabular}




\subsection{CONCLUSIONS}

The seisric analysis of a typical nuclear power plant shear wall structure was performed for a series of site and foundation conditions. Best estimate and desigr, procecures here used. Comparisons between best estimate results allows one to quantify the effects of placing the identical structure on different sites and founding it in different manners. Comparisons between responses calculated by simplifjed SSI design procedures and those calculated by best estimate procedures, allows one to develop caltbration factors. These factors can be used to estimate median level responses irom design values accounting for SSI analysis procedures.

Results presented here emphasized in-structure responses which are scalars, i.e. peak accelerations and peak forces. These quantities can be investigated in the context of calibration factors. The difficulty of treating in-structure response spectra in the same marner has been demonstrated. Hence, in this latter case, comparison of spectra themsejves is preferred. 


\subsection{REFERENCES}

1. Smith, P. D. et al., "Seismic Safety Margins Research Program-Phase I Final Report," UCRL-53021, also NUREG/CR-2015, Vol. 1, 1981.

2. Bohn, M. P. et al., "Application of the SSMRP Methodology to the Seismic Risk at the zion Nuolear Power Plant," UCRL-53483, also NUREG/CR-3428, 1983.

3. Johnson, J. J., Goudreau, G. L., Bumpus, S. E., Maslenikov, o. R., "Seismic Safety Margins Research Proeram Phase I Final Report - SMACS - Seismic Methodology Analysis Chain witis Statistics (Project VII)," UCRL-53021, also NUREG/CR-2015, Vol. 9, 1981.

4. Benda, B. J., Johnson, J. J., LO, T. Y., "Seismic Safety Margins Researih Program Phase I Final Report -- Major Structure Response (Project IV), UCRL-53021, also NUREG/CR-2L15, Vol. 5, 1981.

5. Richart, F. E., Hall, J. R., Woods, R. D., Vibrations of Solls ard Foundations, Prentice-Hall, Inc., Englewood Cliffs, N. J., 1970 .

6. Johnson, J. J., Schewe, E.C., Masienlkov, O. R., "SSI Response of a Typical Shear Wall Structure: In-Structure Response Spetra Comparisons," SMA \$12209.23.02, ApriI 1984. 
APPENDIX A

A- 1. 


\section{APPENDIX A \\ CATEGORIZATION OF NUCLEAR POWER PLANT CHARACTFRISTICS}

A summary of seismic analysis and design information for the seventy-one nuclear power plants with operating licenses as of approximately April 1980 is contained here. The data was principally taken from Refs. $A 1$ and $A 2$. Six categorjes were identified and itemized in detail in Table Al:

- General Data -- Plant name, utijity, A-E, NSSS manufacturer, reactor type, site classification, structures, and embedment conditions.

- Desigr Earthquake Definition -. Peak ground acceleration, design response spectra, etc.

- SSI analysis -- Method of analysis, structure model, soil damping, etc.

- Generation of Floor Spectra - Nethod of generating spectra, structure model, number of earthquake components, etc.

- Generation of Forces in Structure - Rethod of anajsis, modal combination, directional combination, etc.

- Structure Damping used -. Helded steel components, bolted sieel components, reinforced concrete, prestressed concrete. 
These six general categories are broken down in detail in Table A1. The resulting compilation of information has been encoded in a computer data file which permits sorting and easy compilation of summary data. To do so, numerical code numbers are identified with each attribute in a category. These code numbers are 1 isted in Table $A 1$.

Table A2 presents al] nuclear power plants considered and the data accumulated for each. Table A2 presents the data in total with no attempt made to sort it. Tables $A 3$ - $A 8$ present the results of sorting the data and compiling summaries for the following categories:

Table A3 - Distribuition of Plants by Site C.jassification and Soil Mode]

Table A4 - Distribution of Plants by Method of Generating In-Structure Forces, by Number and Method of Combination of Simultaneous Earthquake Components and by Methed of Combining Modal Respor ?

Table A5 -- Distribution of Plants by Damping Ratio used for Welded steel Components and by Design Ground Response Spectrum

Table A6 - Distribution of plants by Damping Ratio used for Bolted Steel Components and by Design Ground Response Spectrum

Table A7 - Distribution of Plants by Damping Ratio used for Reinforced Concrete Components and by Desizn Ground Response Spectrum 


\section{Table A8 - Distribution of Plants by Damping Ratio used for Prestressed Concrete Components and by Design Ground Response Spectrum}

\section{References}

A1. Subuchi, M., Reich, M., Koplik, B., Lane, J., "Seismic Reviek Table," Brookhaven National Laboratory, NUREG/CR-1429, 1980.

A2. Dames and Moore, "Site Pajameter Study GASSAR Seismic Design for Genera] Atomic Company," 1974. 


\title{
PLANT CLASSIFICATION
}

- GENERAL DATA

$\begin{array}{ll}1.1 & \text { Plant Identifier } \\ 1.2 & \text { Utility } \\ 1.3 & \text { Architect/Engineer } \\ 1.4 & \text { NSSS Manufactular } \\ 1.5 & \text { Reactor Type } \\ 1.6 & \text { Site Classification } \\ 1.7 & \text { Structure } \\ 1.8 & \text { Embedment Conditions }\end{array}$

\section{DESIGN EARTHQUAKE DEFINITION}

2.1 Number of Freefield Earthquake Components

2.2 Excitation Levels (OBE/SSE)

2.3 Horizontal SSE PGA

2.4 Ratio of Vertical to Horizontal SSE FGA

2.5 Design Response Spectrum

2.6 Type of Time History

2.7 Location of Control Point

\section{SSI ANALYSIS}

\author{
3.1 Method of Analysis \\ 3.2 Structural Model \\ 3.3 Number of Simultaneous Earthquake Components \\ 3.4 Combination of Earthquake Components \\ 3.5 Combination of Modal Response \\ 3.6 Method of Modeling Soil \\ 3.7 Soil Damping \\ 3.8 Treatmeil of Embedment
}

\section{GENERATION OF FLOOR SPECTRA}
4.1 Method of Generating Horizontal Spectra
4.2 Method of Generating Vertical Spectra
4.3 Method of Analysis
4.4 Structural Modei
4.5 Number of Simultoneous Ear:hquake Components
4.6 Combination of Earthquake Components 
Table Al (Cont.)

5. GENERATION OF FORCES IN STRUCTIRE

5.1 Method of Analysis

5.2 Structural Model

5.3 Number of Simultaneous tartiquake Components

5.4 Combinatien of Earthquake Components

5.5 Combination of Modal Response

6. STRUCTURE DAMPING USED (OBE/SSE)

Welded Steel Components

Bolted Steel Components

Reinforced Concrete

Prestressed Concrete 


\section{GENERAL DATA}

\subsection{PLANT IDENTIFIER}

\begin{tabular}{|c|c|}
\hline 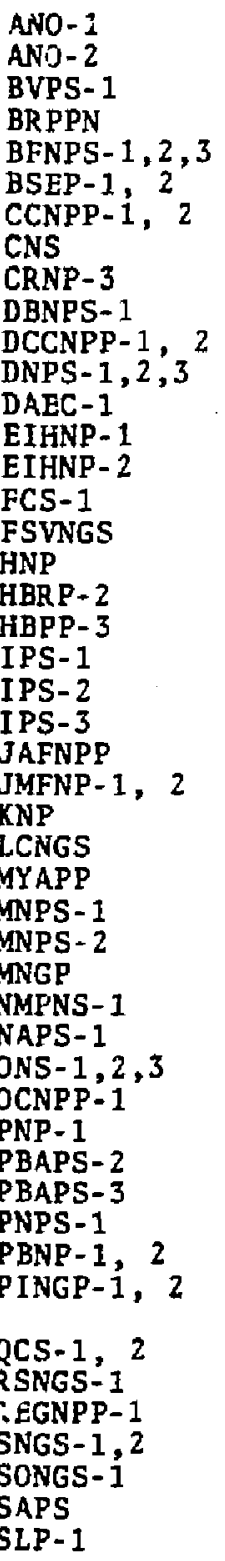 & 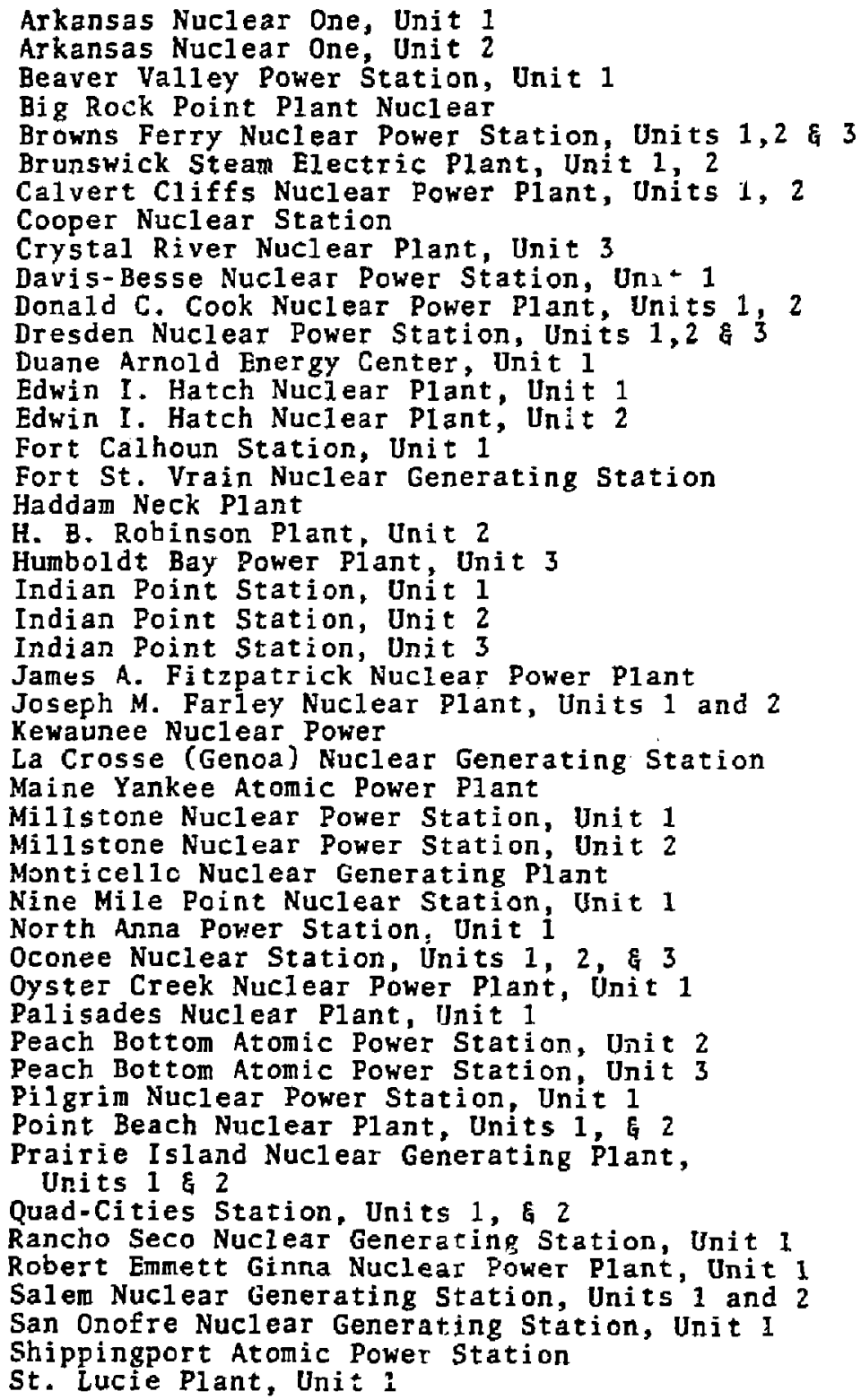 \\
\hline
\end{tabular}




\section{Table Al (Cont.)}

SPS- 1,2 TMINS-1 TMINS- 2

TNP-1

TPP - 3, 4 VYNPS

YRNPS

ZNP - 1,2
Surry Power Station, Units $1, \& 2$

Three Mile Island Nuclear Station, Unit 1 Three Mile Island Nuclear Station, Unit 2 Trojan Nuclear Plant, Unit 1

Turkey Point Plant, Units 3 \& 4

Vermont Yankee Nuclear Power Station

Yankee-Rowe Nuclear Power Station

Zion Nuclear Plant, Units 1 , \& 2 


\subsection{UTILITIES}

Arkansas Power \& Light Co. ...................... Duquesne Light, ohio Edison \& Penn. Power Co.......... 02

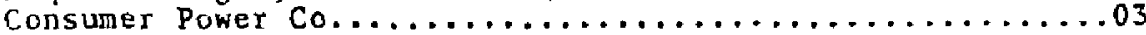

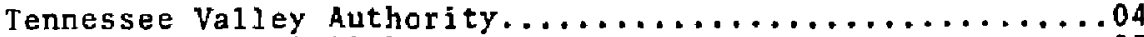

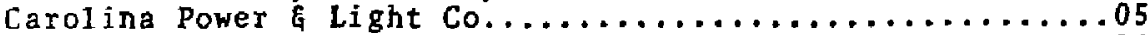
Baltimore Gas E Electric Co...................... Nebraska Public Power $G$ Iowa Powerlight Co............. 07 Florida power Corp........................... 08 Cleveland Electric Co........................ 09 Indiana \& Michigan Electric Co................... Commoniealth Edison Co....................... Iowa Elec. Light \& Power, Cent. Iowa Pwr. E Corn Belt Pwr.12 Yankee Atomic Electric Co......................13

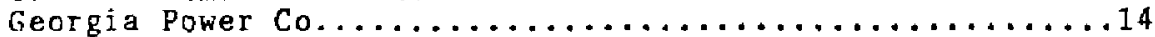

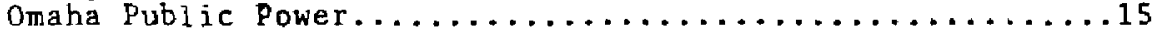

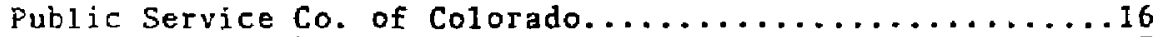
Connecticut Yankee Atomic Power................... 17

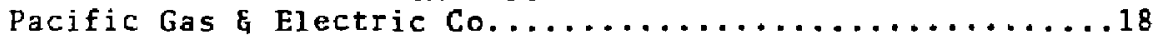

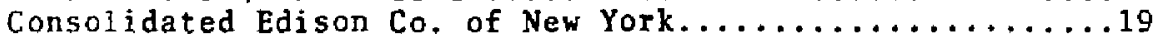

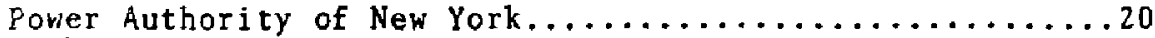

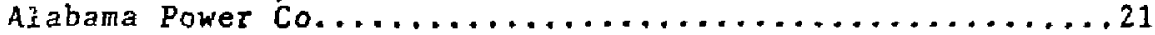
Wisconsin Public Service Co......................22

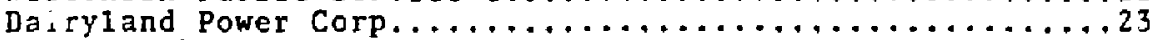

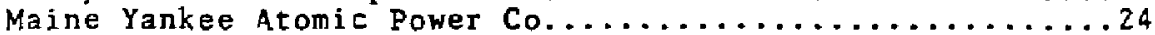

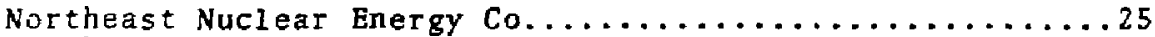

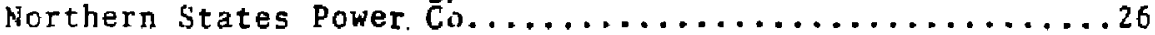
Ni agara Mohawk Power Corp.................... 27 Virginia Electric \& Power Co...................28

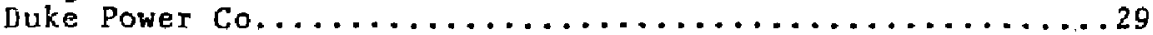

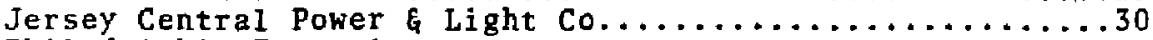
Philadelphia Electric Co......................

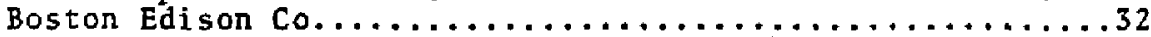
Wisconsin Electric Power $\mathscr{G}$ Wisconsin Michigan Power Co... 33 Commonweal th Edison E Iowa-Illinois Gas E Electric Co....34 Sacramento Municipal Utility Dist................. 35

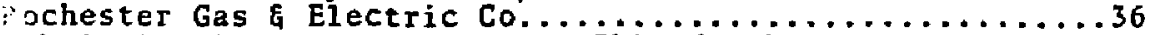
ublic Service Electric E Gas, Philadelphia Electric Atlantic City Electric \& Delmarva Power E Light Co.......37 Southern California Edison $\&$ San Diego Gas E Electric Co..38

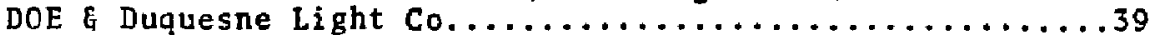
Metropolitan Edison Co....................... Portland General Electric Co....................41

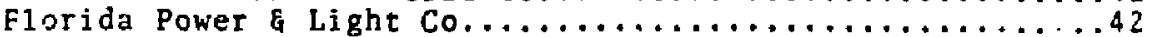
Vermont Yarkee Nuclear Power Corp................... 43 


\subsection{ARCHITECT/ENGINEERS}

Bechtel ................................ 01

Stone \& Webster............................. 02

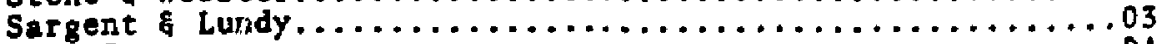

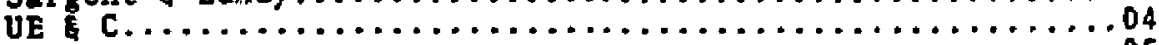

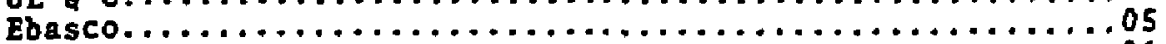

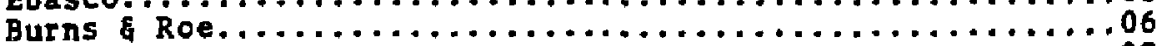

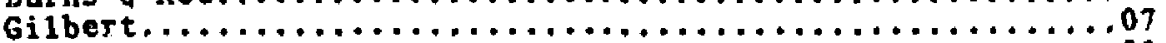

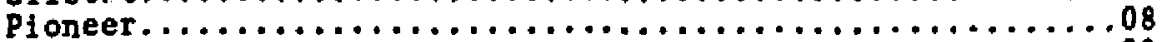

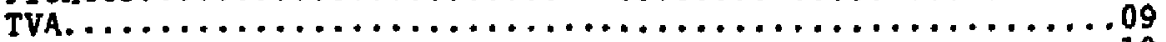

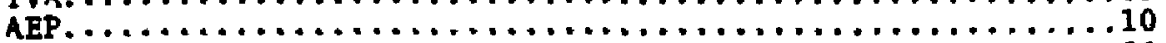

Gibbs Hil1...................................

\subsection{NSSS MANUFACTURERS}

Hestinghouse............................. 1

Goneral Electric.............................

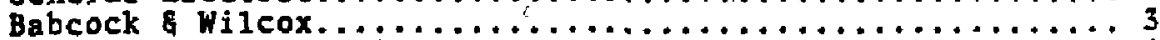

Combustion Engineering.......................

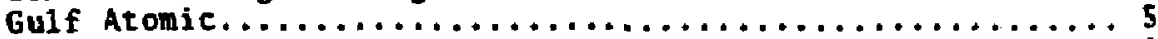

AC. ...................................

\subsection{REACTOR TYPE}

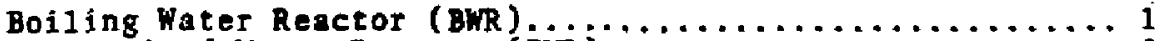

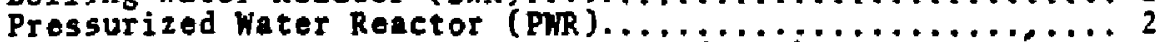

High Temperature Gas Cooled Reactor (HTGRj............. 3

\subsection{SITE CLASSIFICATIJN}

Rock Sites (less than $20 \mathrm{ft}$. of seil), Plutonic Bedrock... 1X

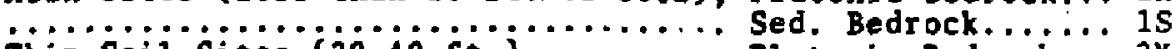
Thin Soil Sites (20-40 ft.), Plutonic Bedrock... 2X ............................. 2s Intermediate Soil sites $(50-100 \mathrm{ft}$ ) , Futonic Bedrock... 3x

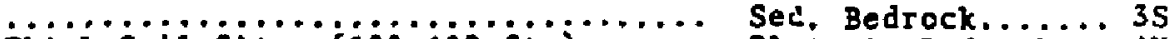
Thick Sojil sites $(i 00-400$ ft.j, ... Plutonic Bedrack... 4X .......................... Sed. bodrock...... 4 S Extra Thick Soil Sites, (h 400 ft.) 
Table Al (Cont.)

\subsection{STRUCTURE}

All Structures or unspecified.................. 0 Reactor Building (Containment \& Internal Structure)..... 1 Auxiliary Building......................... 2 Turbine Building........................... 3 Intake Structure............................ 4 Reactor Building Internal .................... 5 Fuel Handling/Storage Building.................. 6

Containment and Auxiliary Building............... 7

\subsection{EMBEDMENT CONDITIONS}

No Embedment............................. 0

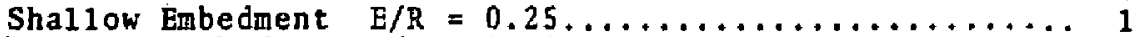

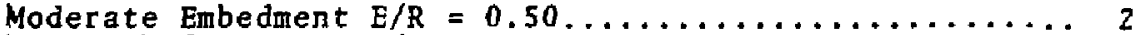
Deep Embedment $\quad E / R=0.75 \ldots \ldots \ldots \ldots \ldots \ldots \ldots \ldots$ Foundation Mat on Piles....................... 4 
Table Al (Cont.)

\section{DESIGN EARTHQUAKE DEFINITION}

\section{I NUMBER OF FREEFIELD EARTHQUAKE COMPONENTS}

The number of freefield earthquake comporents for which there is a different response spectrum or time history.

\subsection{EXCITATION LEVELS (OBE/SSE)}

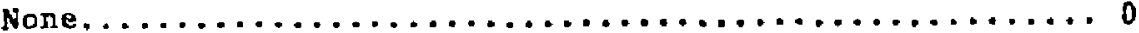

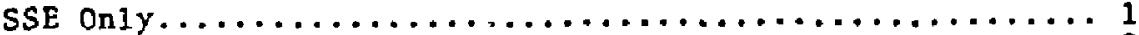

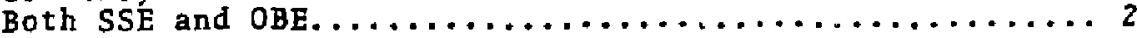

\subsection{HORIZONTAL SSE PGA}

The peak ground acceleration defined for the horizontal component of the safe shutdown earthquake (SSE).

\subsection{RATIO OF VERTICAL TO HORIZONTAL SSE PGA}

The ratio of peak ground accelerations of the SSE vertical component to the SSE horizontal conponent.

\subsection{DESIGN RESPONSE SPECTRUM}

Not Available..............................

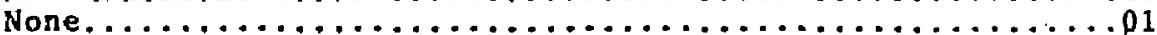

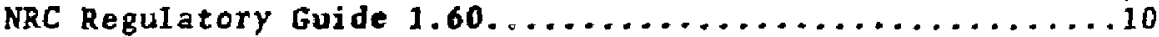

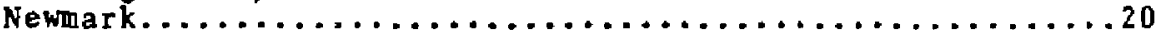

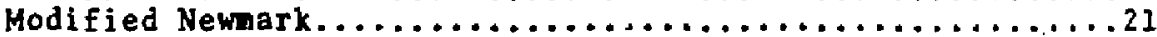

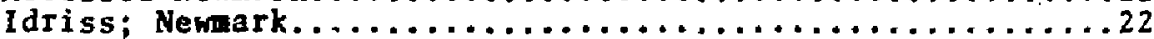

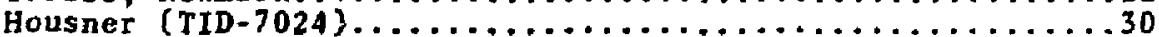

Housner; Newmark........................... 31

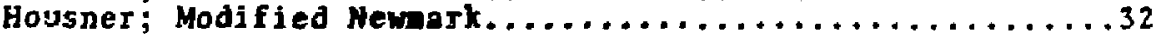

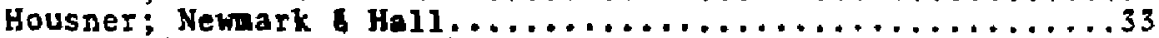

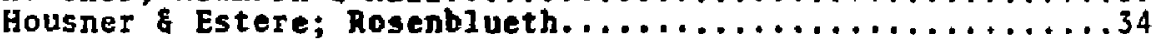

Housner; site specifjc...................... $\ldots \ldots$

Housnezlel Centro (1940) enveloped.................. 37

Golden Gate Park (1952); Housner..................... 38

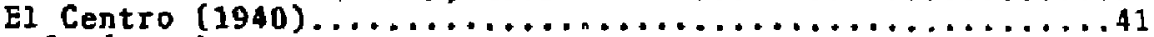

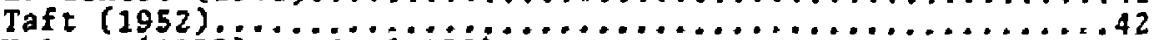

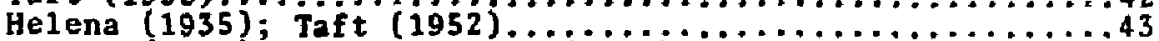

Helena $(1935)$; San Francisco $(1957) \ldots \ldots \ldots \ldots \ldots \ldots \ldots \ldots \ldots 4$

Golden Gate Park (1952)/El Centro (1940)...............45

Golden Gate Park (1952)/El Centro $(1940) \ldots \ldots \ldots \ldots \ldots$

A- 12 
Table Al (Cont.)

\subsection{TYPE OF TIME HISTORY}

None. ....................................

Synthetic Time History....................... 1

Real Earthquake Time History...................

\subsection{LDCATION OF CONTROL POINT}

Not Applicable.......................... 0

At Ground Surface........................ 1

At Foundation Level...................... 2 


\section{SSI ANALYSIS}

\subsection{METHOD OF ANALYSIS}

None, Not Applicable or Indicated Elsewhere.......... 0

Modal Time History Analysis.................... 1

Modal Response Spectrum Analysis................ 2

B. rect Integration Analysis.................... 3

Fourier Aralysis.......................... 4

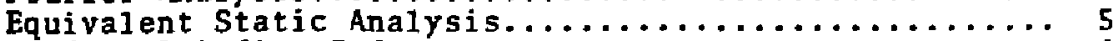

Uniform Building Code...................... 6

\subsection{STRUCTURAL MODEL}

Not Applicable......................... 0

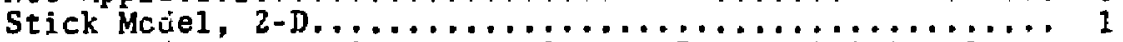

Stick Model, 3-D with Floor \& Hall Eccentricities Incl, 2

Finite Element Model, 2-D.................... 3

Finite Element Model, $3-D \ldots \ldots \ldots \ldots \ldots \ldots \ldots \ldots \ldots \ldots \ldots$

Finite Element Model, Axisymmetric............... 5

\subsection{NUMBER OF SIMULTANEOUS EARTHQUAKE COMPONENTS}

None. ............................. 0

One Horizontal or One Vertical.................. 1

One Horizontal \& Vertical....................... 2

Both Horizontals \& Vertical..................... 3

\subsection{COMBINATION OF EARTHQUAKE COMPONENTS}

No Combination.......................... 0

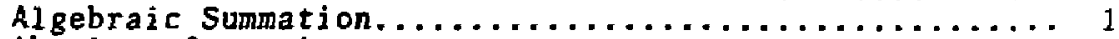

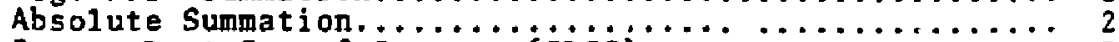

Square-Root-Sum-of-Squares (SRSS) ............... 3

\subsection{COMBINATION OF MDDAL RESPONSE}

Not Applicable.......................... 0

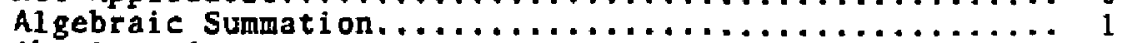

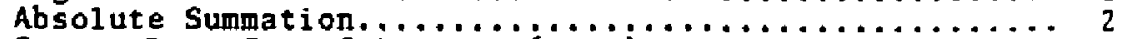

Square-Root-Sum- of-Squares $($ sRss) ................. 3

NRC Reg. Guide $1.92 \ldots \ldots \ldots \ldots \ldots \ldots \ldots \ldots \ldots \ldots \ldots \ldots$ 
Table Al (Cont.)

\subsection{METHOD OF MODELING SOIL}

None: Fixed-Base or No Analysis Done...............000

Spring Constants (Frequency Independent)............100

Concentrated Springs (Rigid Foundation)...........110

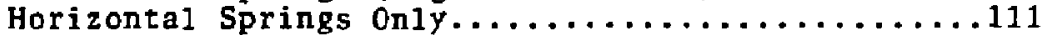

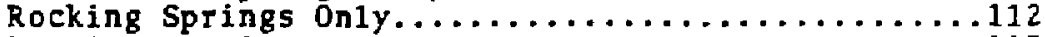

Vertical Springs only.....................113

Horizontal \& Rocking Springs.................114

Horizontal, Rocking and Vertical Springs.........115

Horizontal, Rocking, Vertical \& Torsional Springs..116

Distributed Springs (Flexible or Rigid Foundation)...120

Horizontal Springs on1y..................121

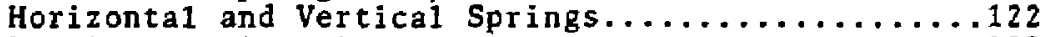

Vertical Springs only..................... 123

Impedance Functions (Frequency Dependent Springs).....200

Concentrated (Rigid Foundation)..............210

Distributed (Flexible Foundation)...............220

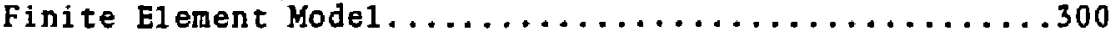

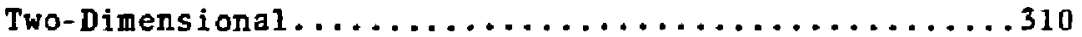

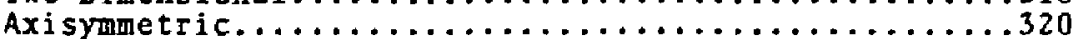

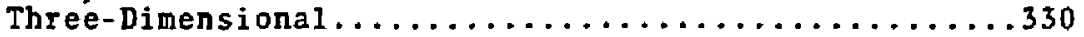

\subsection{SOIL DAMPING}

Not Considered............................ 00

Composite Modal Damping..................... 10

With Limitation on Damping..................... 11

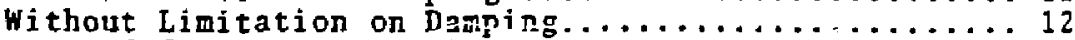

Accounted for Separately in Soil................. 20

Considered, but method of Inclusion not Specified..... 30

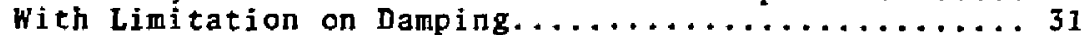

Without Limitation on Damping............... 32

\subsection{TREATMENT OF EMBEDMENT}

Not Considered......................... 0

Included Only as Modified Soil Springs.............. I

Included as Modified Soil Springs and Input Motion..... 2 
TABLE A.1 (Cont.)

. 4. GENERATION OF FLOOR SPECTRA

\subsection{METHOD OF GENERATING HORI2ONTAL SPECTRA}

None................................... 0

Ground Spectra Used........................ 1

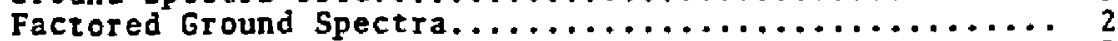

Dynamic Analysis........................... 3

\subsection{METHOD OF GENERATING VERTICAL SPECTRA}

None.

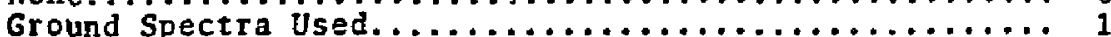

Factored Ground Spectra...................... 2

Dynamic Aralysis......................... 3

\subsection{METHOD OF ANALYSIS}

None or Not Applicable..................... 0

Modal Time History Analysis.................... 1

Modal Response Spectrun Analysis................. 2

Direct Integration Analysis................... 3

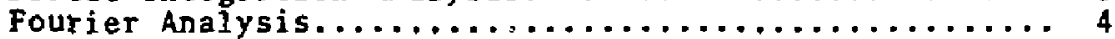

Equivalent Static Analysis.................... 5

Uni form Building Code........................... 6

\subsection{STRUCTURAL MODEL}

Not Applicable............................ 0

Stick Model, 2-D........................... 1

Stick Model, 3-D with Floor E Wall Eccentricities Incl. 2

Finite Element Model, $2-D \ldots \ldots \ldots \ldots \ldots \ldots \ldots \ldots \ldots \ldots \ldots \ldots$

Finite Element Mode1, $3-D \ldots \ldots \ldots \ldots \ldots \ldots \ldots \ldots \ldots \ldots \ldots \ldots$

Finite Element Model, Axisymmetric............... 5

\subsection{NUMBER OF SIMULTANEOUS EARTHQUAKE COMPONENTS}

None ....................................

One Horizontal or one vertical ..................

One Horizontal $\&$ Vertical........................

Both Horizontals $\varepsilon$ Vertical.....................

\subsection{COMBINATION OF EARTHQUAKE COMPONENTS}

No Combination. ........................ 0

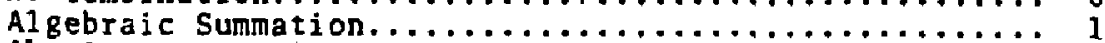

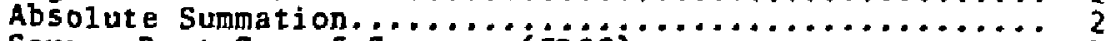

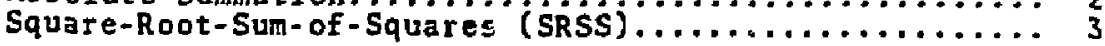


Table Al (Cont.)

\section{GENERATION OF FORCES IN STRUCTURE}

\subsection{METHOD OF ANALYSIS}

None or Noi Applicable......................

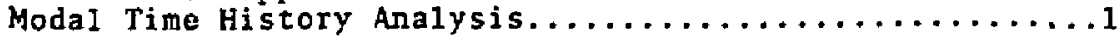

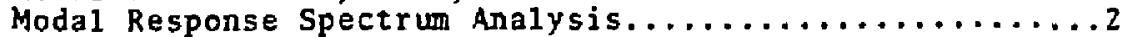

Direct Irtegration Analysis.....................

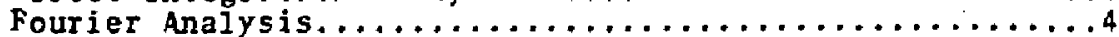

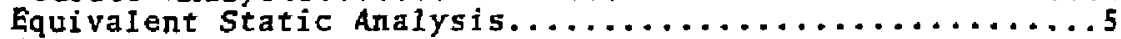

Uniform Building Code.......................

\subsection{STRUCTURAL MODEL}

Not Applicable............................ 0

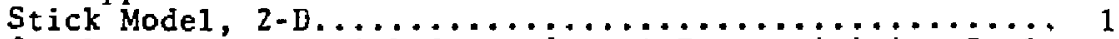

Stick Model, 3-D with Floor \& Wall Eccentricities Incl, 2

Finite Element Model, $2-D \ldots \ldots \ldots \ldots \ldots \ldots \ldots \ldots \ldots \ldots$

Finite Element Model, $3-D \ldots . \ldots \ldots \ldots \ldots \ldots \ldots \ldots \ldots$

Finl ie Element Model, Axisymmetric............... 5

\subsection{NUMBER OF SIMULTANEOUS EARTHQUAKE COMPONENTS}

None .................................. 0

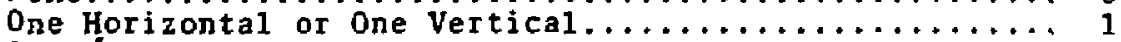

One Horizontal $\&$ Vertical...................... 2

Both Hotizontals \& Vertical................... 3

\subsection{COMBINATION OF EARTHQUAKE COMPONENTS}

No Combination. ........................

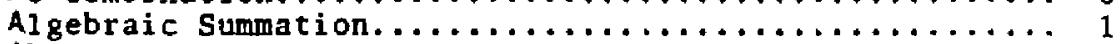

Absolute summation.......................... 2

Square-Root-Sum- of-Squares (SRSS).............. 3

\subsection{COMBINATION OF MODAL RESPONSE}

Not Aoplicable........................... 0

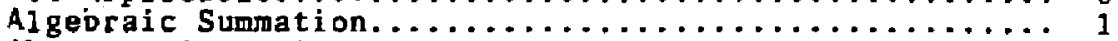

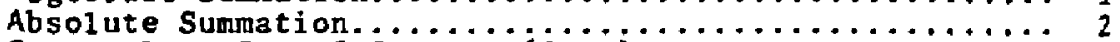

Square-Root-Sum- of-Squares (SRSS) ............... 3

NRC Reg. Guide 1.92 or equivalent................ 4 


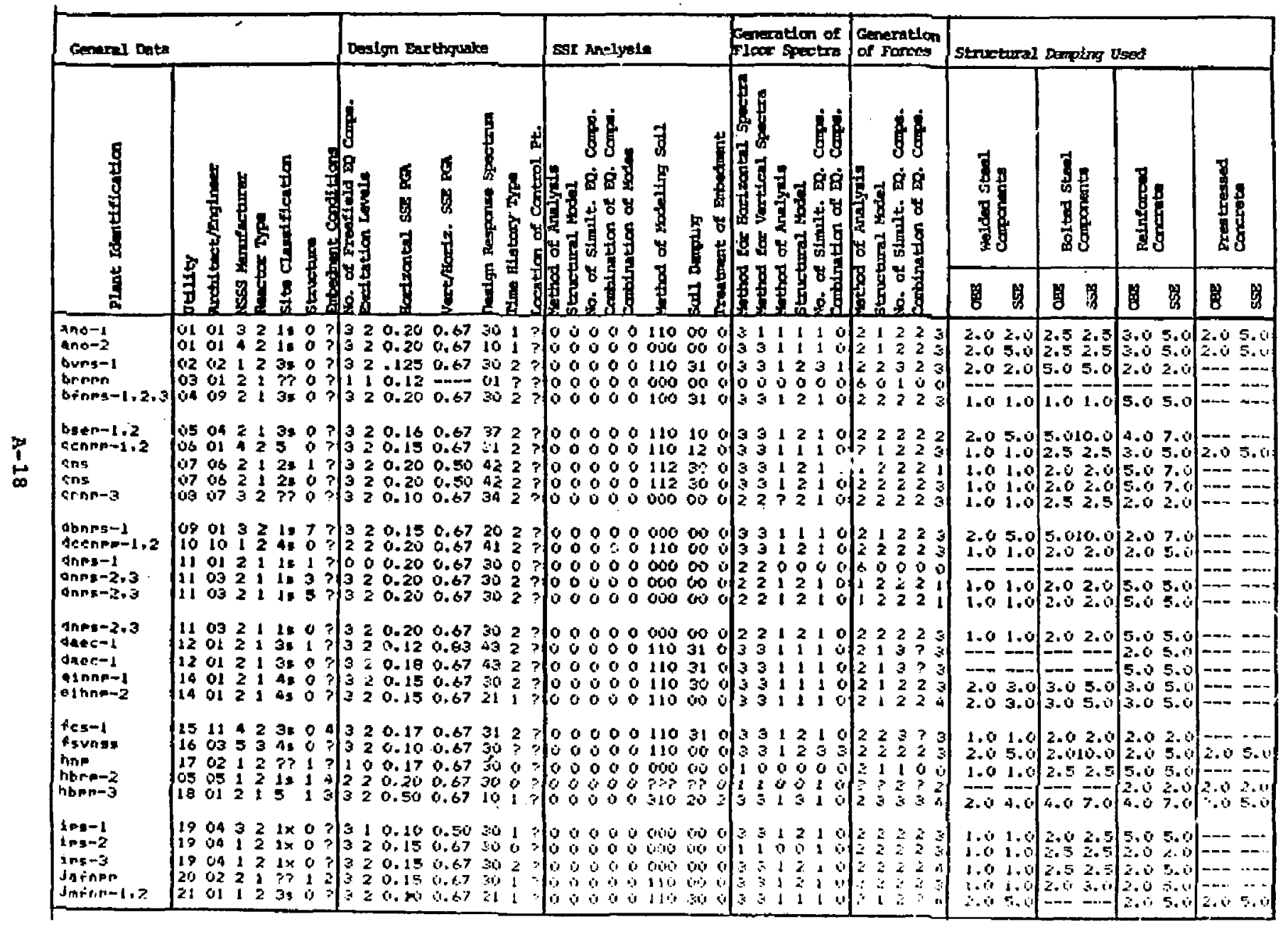




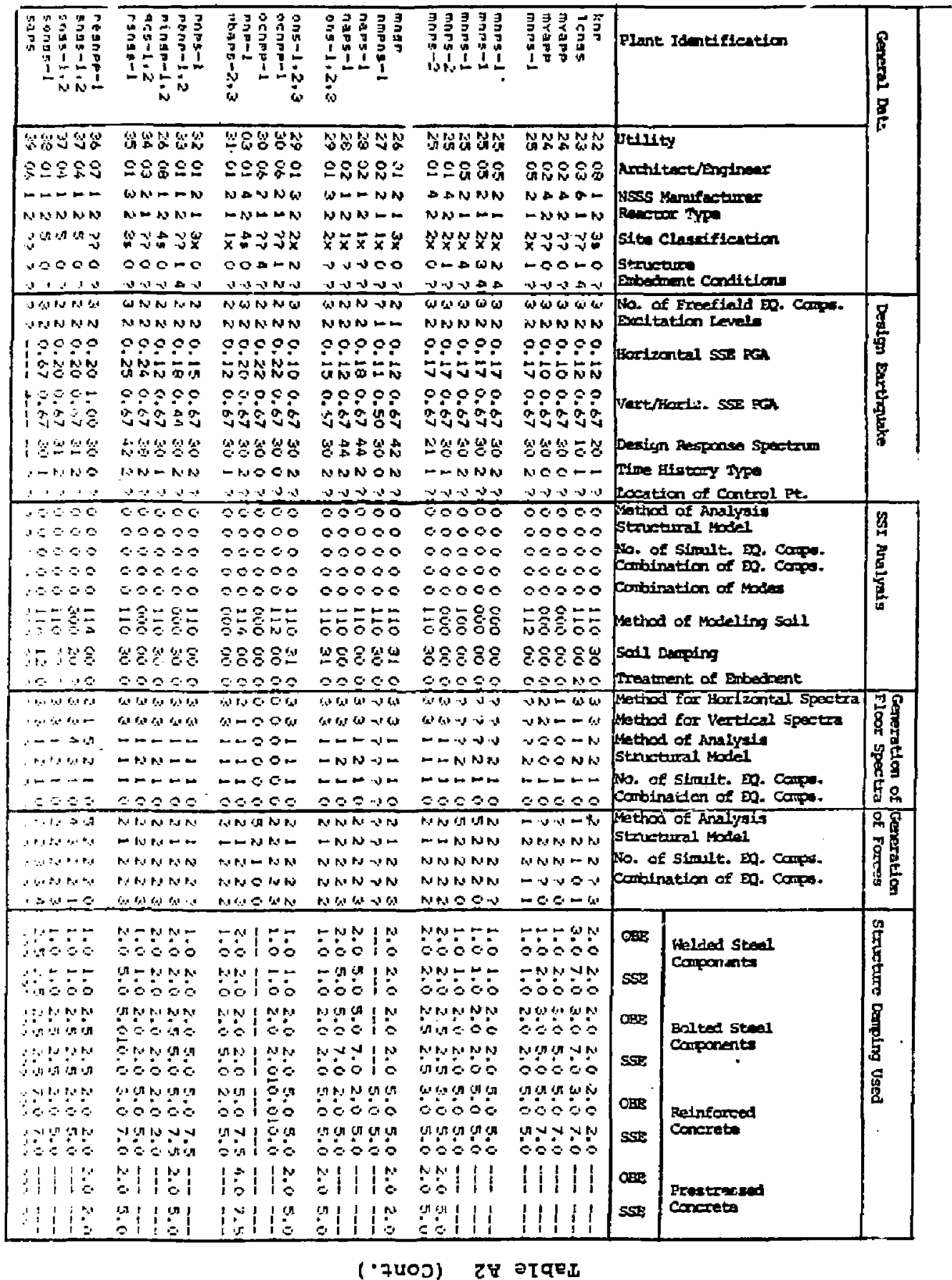




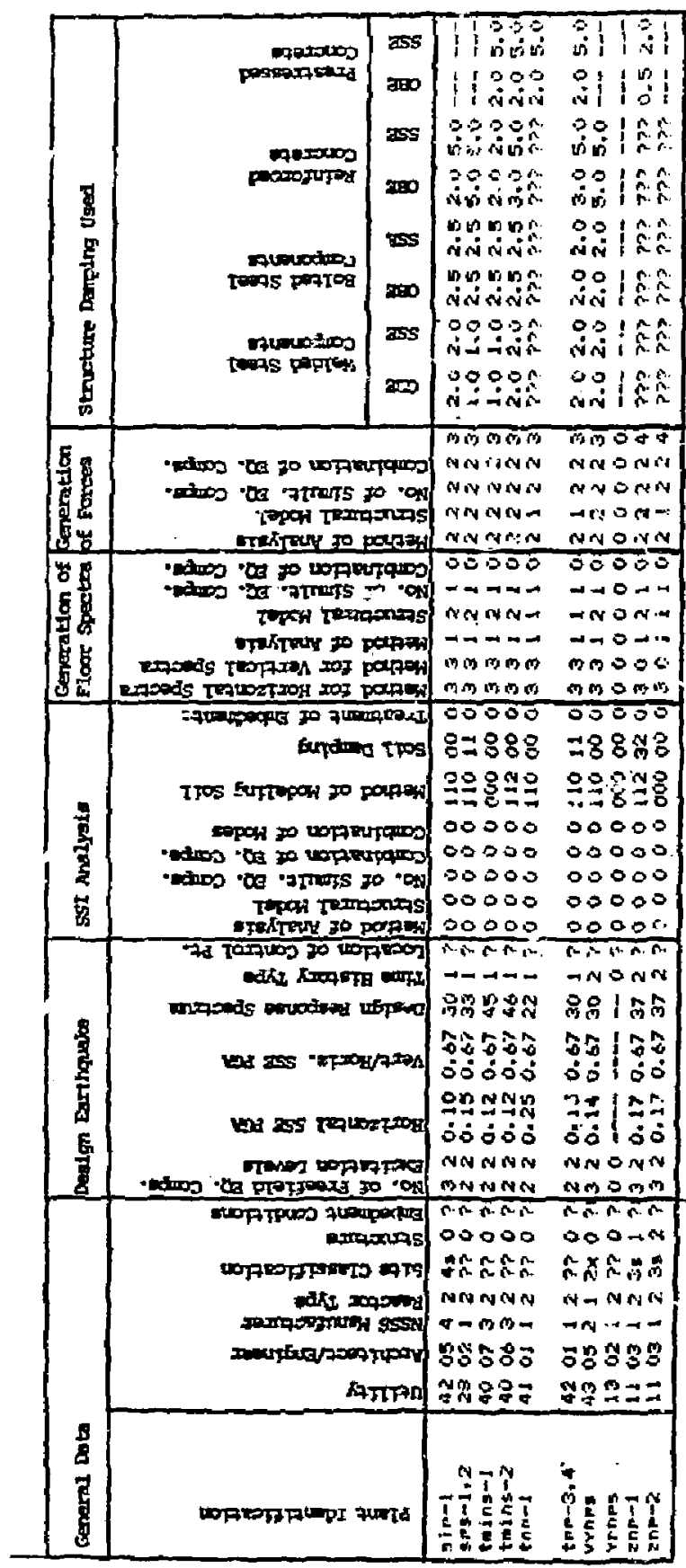

A-20 


\section{DISTRIBUTION OF PLANTS BY SITE CLASSIFICATION AND SOIL MODEL}

Distribution of Plants by Method of Modelling Soil

\section{Site Classification}

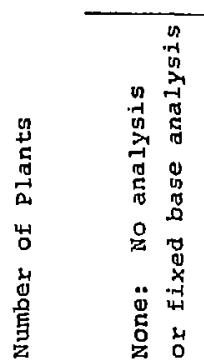

吾
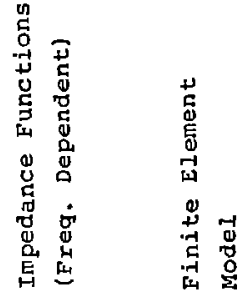

\section{Rock Sites}

Less than $20 \mathrm{ft}$. of soil.

2. Thin Soil sites 20-40 ft. of soil 
DISTRIBUTTOA OF PLANTS BY METHOD OF GENERATING IN-STRUCTURE FORCES, BY RUNBER AND METHOD OE COMBINATION OE SIMULTANEOUS EARTHOUAKE COMPONEMTS

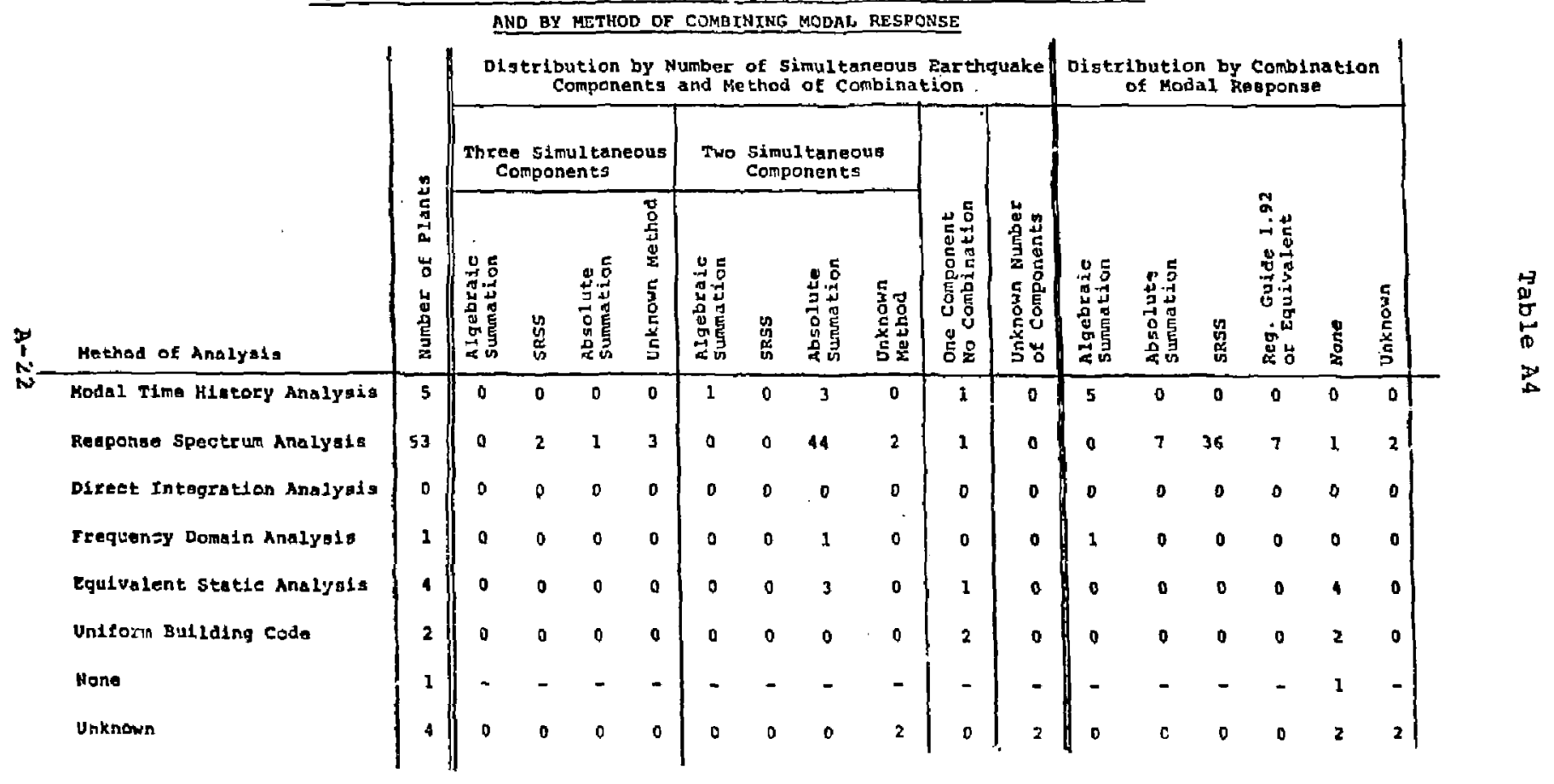


DISTRIBUTION OF PLANTS BY DAMPING RATIO USED FOR

WELDED STEEL COMPONENTS AND BY DESTGN GROUND RESPONSE SPECTRUM

\begin{tabular}{|c|c|c|c|c|c|c|c|}
\hline \multirow{2}{*}{$\begin{array}{l}\text { Damping } \\
\text { Ratio } \\
\text { (Percent) }\end{array}$} & \multirow[b]{2}{*}{$\begin{array}{l}\text { Number of } \\
\text { Plants }\end{array}$} & \multicolumn{5}{|c|}{ Distribution by Type of Design Ground Response Spectrum } & \multirow[b]{2}{*}{ Unknow } \\
\hline & & $\begin{array}{c}\text { Res. Guide } \\
\text { 1. } 60\end{array}$ & Newmark & Housner & $\begin{array}{c}\text { Real } \\
\text { Earthquake }\end{array}$ & None & \\
\hline 1.0 & 28 & 0 & 0 & $\begin{array}{c}24 \\
(0.10-0.24)\end{array}$ & $(0.12-0.20)$ & 0 & 0 \\
\hline 2.0 & 17 & 0 & $(0.12-0.17)$ & $\begin{array}{c}13 \\
(0.10-0.20)\end{array}$ & $\begin{array}{c}2 \\
(0.12)\end{array}$ & 0 & 0 \\
\hline 2.5 & 1 & 0 & 0 & $\begin{array}{c}1 \\
(0.67)\end{array}$ & 0 & 0 & 0 \\
\hline 3.0 & 2 & 0 & $\begin{array}{c}1 \\
(0.15)\end{array}$ & $(0.15)$ & 0 & 0 & 0 \\
\hline 4.0 & 1 & $\begin{array}{c}1 \\
(0.50)\end{array}$ & 0 & o & 0 & 0 & 0 \\
\hline 5.0 & 8 & $\frac{1}{(0.20)}$ & $\frac{2}{(0.10-0.15)}$ & $(0.10-0.16)$ & $\stackrel{3}{3}(0.12-0.25)$ & 0 & 0 \\
\hline 7.0 & 1 & $\frac{1}{(0.12)}$ & 0 & 0 & 0 & 0 & 0 \\
\hline Unknown & 12 & 0 & $(0.25)$ & $\begin{array}{c}6 \\
(0.11-0.22)\end{array}$ & $\stackrel{2}{2}(0.12-0.18)$ & $\begin{array}{c}1 \\
(0.12)\end{array}$ & 2 \\
\hline Total & 70 & 3 & 6 & 47 & 11 & 1 & 2 \\
\hline
\end{tabular}

\footnotetext{
Note: Numbers in parentheses "give ranges of SSE peak ground accelerations in g-units.
} 
DISTRIBUTION OF PLANTS BY DAMPING RATIO USED FOR

BOLTED STEEL COMPONENTS AND BY DESIGN GROUND RESPONSE SPECTRUM

Distribution by Type of Design Ground Response Spectrum

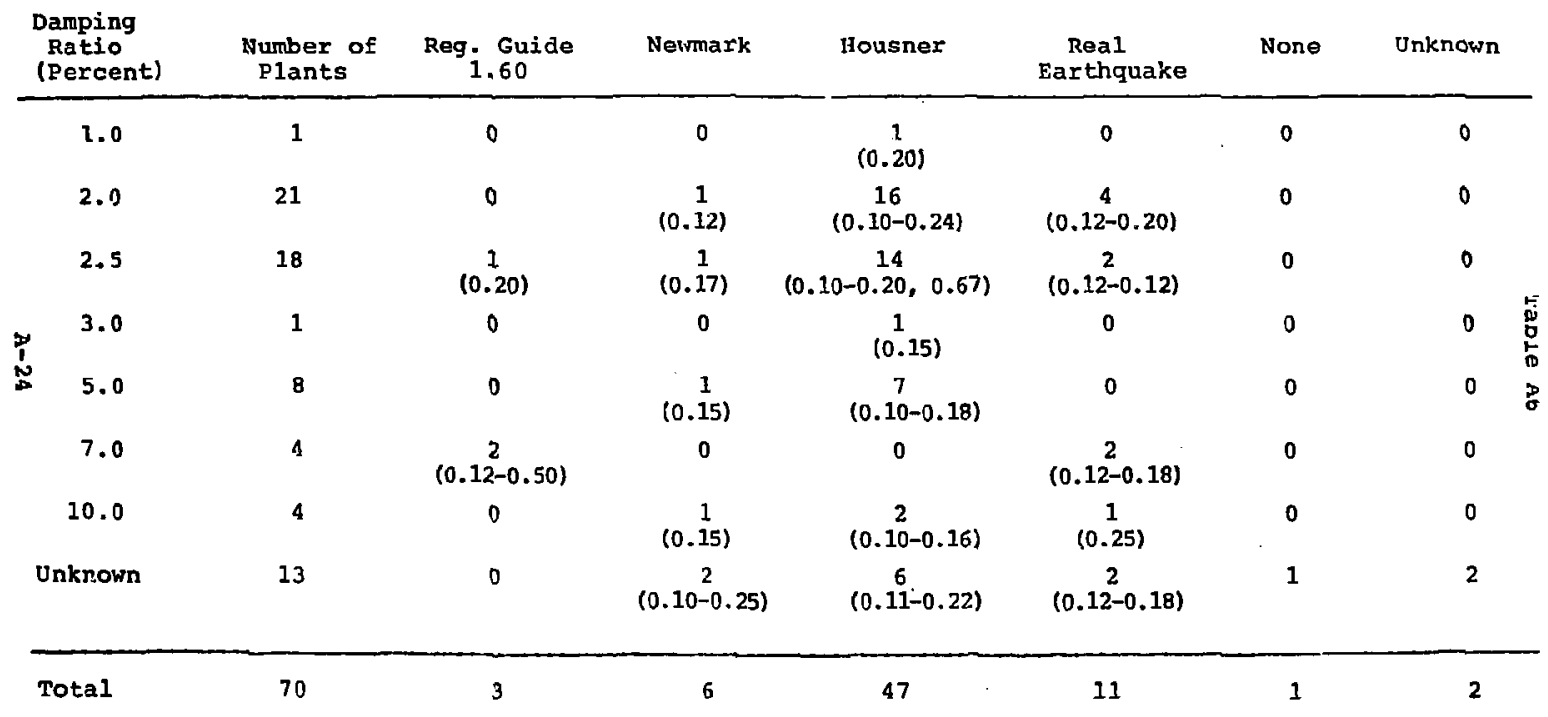

Note: Numbers in parentheses give manges of sSE peak ground accelerations in $g-u n i t s$. 
DISTRIBUTION OF PLANTS BY DAMPING RATIO USED FOR REINFORCED CONCRETE COMPONENTS AND BY DESIGN GROUND RESPONSE SPECTRUM

\begin{tabular}{|c|c|c|c|c|c|c|c|}
\hline \multirow[b]{2}{*}{$\begin{array}{l}\text { Damping } \\
\text { Ratio } \\
\text { (Percent) }\end{array}$} & \multirow[b]{2}{*}{$\begin{array}{l}\text { Number of } \\
\text { Plants }\end{array}$} & \multicolumn{6}{|c|}{ Distribution by Type of Design Ground Response Spectrum } \\
\hline & & $\operatorname{Reg}_{j .60}^{\text {Guide }}$ & Newmark & Housner & $\begin{array}{c}\text { Real } \\
\text { Earthquake }\end{array}$ & None & Unknows \\
\hline 2.0 & 9 & 0 & $(0.12)$ & $\left(0.10^{7}-0.20\right)$ & $(0.12)$ & 0 & 0 \\
\hline 5.0 & 39 & $(0.12)$ & $\begin{array}{c}3 \\
(0.10-0.17)\end{array}$ & $\begin{array}{c}28 \\
(0.10-0.24)\end{array}$ & $\begin{array}{c}7 \\
(0.12-0.20)\end{array}$ & $\mathbf{0}$ & $\mathbf{0}$ \\
\hline 7.0 & 10 & $\stackrel{2}{2}(0.12-0.50)$ & $(0.15)$ & $(0.10-0.16,0.67)$ & $\stackrel{3}{(0.20-0.25)}$ & 0 & 0 \\
\hline 7.5 & 3 & 0 & 0 & $\left(0.15^{3}-0.20 j\right.$ & 0 & 0 & $\mathbf{0}$ \\
\hline 10.0 & 1 & 0 & 0 & $\begin{array}{c}1 \\
(0.22)\end{array}$ & 0 & 0 & 0 \\
\hline Unknown & 8 & 0 & $\begin{array}{c}1 \\
(0.25)\end{array}$ & $\stackrel{4}{(0.17-0.22)}$ & 0 & $(0.12)$ & 2 \\
\hline Total & 70 & 3 & 6 & 47 & 11 & 1 & 2 \\
\hline
\end{tabular}


DISTRIBUI: :OF PLANTS BY DAMPING RATIO USED FOR

PRESTRESSED CONCRETE COMPONENTS AND BY DESIGN GROUND RESPONSE SPECTRUM

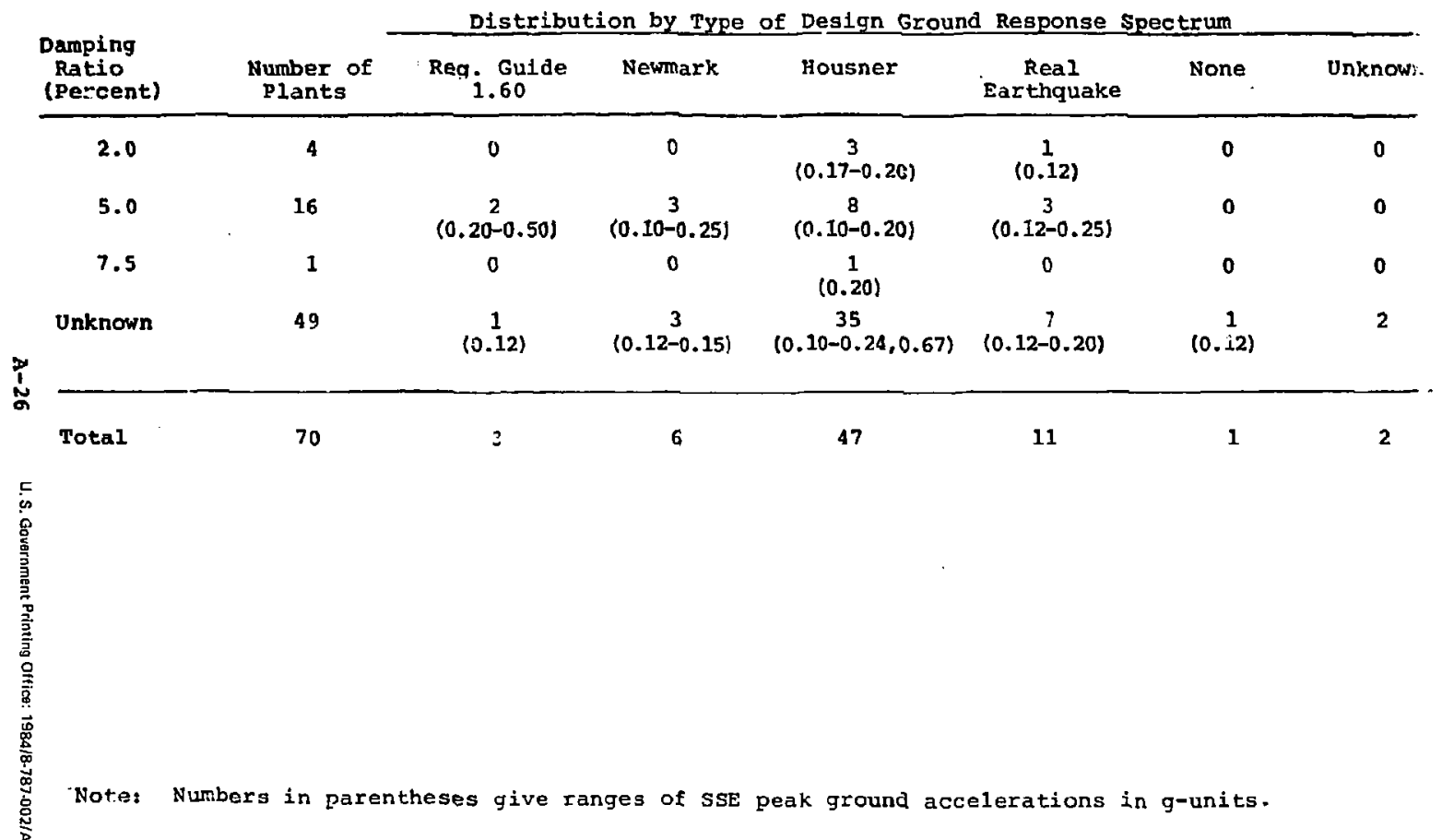

